\title{
O Sistema Tutor de um Ambiente Inteligente para Treinamento e Ensino ${ }^{1}$
}

Mirla Eliane Pereira Freire

)rientação: Prof . Drª. Maria das.Graças Volpe Nunes

Dissertação apresentada ao Instituto de Ciências Matemáticas e de ComputaçãoUSP, como parte dos requisitos para obtenção do titulo de Mestre em Ciencias Área: Ciências de Computação e Matemática Computacional

\section{USP - São Carlos/SP}

\author{
Abril de 1998
}

'Este trabalho teve o apoio financeiro da CAPES. 
Com todo carinho, para Mamãe, Papai e Mayra. 
"Disseram-vos que a vida é escuridão; e no vosso cansaço, repetis o que os cansados vos disseram.

Eu vos digo que a vida é realmente escuridão, exceto quando há um impulso.

E todo impulso é cego, exceto quando há saber.

E todo saber é vão, exceto quando há trabalho.

E todo trabalho é vazio, exceto quando há amor.

E quando trabalhais com amor, vós vos unis a vós próprios, e uns aos outros, e a Deus.

E que é trabalhar com amor? (...)

É semear as sementes com ternura e recolher a colheita com alegria. (...)

É por em todas as coisas que fazeis um sopro de vossa alma."

Gibran Khalil Gibran 


\section{Agradecimentos}

A Deus, pela oportunidade de passar por uma experiência tão enriquecedora e conseguir conciui-la.

À minha família, cujo apoio, força e compreensão foram sempre incentivo para continuar.

Ao Júlio, com quem tenho aprendido muito nestes últimos dois anos, pela paciência, carinho e compreensão.

À Graça, por tudo que fez por mim nesses dois anos e também pela amizade, atenção e principalmente pela compreensão em momentos difíceis pelos quais passei.

À turma (Sandra, Luciano, Veri, Márcia, Karina, Rud, Sil, Fabiano, Kátia, Andréia, Mário, Garga, Ernesto, Luis Carlos, Ana, Jaque, Cris, Chandler, Paulo, Simone, Marisa, Rogério Dei Santi, Larissa, Rejane, Tanão, Tatuí, Gelza, Matite, etc.) pelas festas e momentos inesquecíveis, pela amizade sincera e pelo relacionamento carinhoso. Vou sentir muitas saudades!

Ao pessoal do Intermídia (Elder, Boni, Taboca, Ronaldo, Roger, Manzato, Pagano, Chorfi, Richard, Laércio, Renato, Kutova, Daniel, etc...), pelo companheirismo e pelos momentos divertidos.

Aos funcionários do ICMC, mais especificamente, às meninas da secretaria (Bete, Laura, Marília e Andressa), ao Jaques e ao Paulinho, pela amizade e atenção.

Ao apoio financeiro da CAPES e a todos que de alguma forma tornaram este trabalho possível. 
Este trabalho propõe um ambiente denominado SIATE (Sistema Inteligente de Apoio ao Treinamento e Ensino), que integra características de ambientes de Prática/Treinamento, Hipermídia, Sistemas Tutores e Sistemas Híbridos de Conhecimento, é voltado para o ensino e tem como característica marcante a liberdade, por parte do estudante, de explorar um domínio qualquer, podendo recorrer, quando necessário, ao auxílio de um Sistema Tutor e de um Sistema Híbrido de Conhecimento com conhecimento especialista nesse domínio. São enfatizados aqui o projeto e o desenvolvimento de um Sistema Tutor que oferece apoio pedagógico ao ambiente, bem como o desenvolvimento dos recursos hipermídia desse ambiente. 


\section{Abstract}

This work proposes an environment called SIATE (Sistema Inteligente de Apoio ao Treinamento e Ensino) which integrates features from Hypermedia, Knowledge Based Systems, Tutoring Systems, and Case Based Reasoning. This environment combines approaches of domain exploration by the student with question-answering mechanisms and a simulation-based interface with expert knowledge. The project of the Tutoring System, which provides pedagogic support to SIATE, and the development of the hypermedia resources are described in the text. 


\section{Índice Analítico}

1. INTRODUÇÃO. .10

2. SISTEMAS E RECURSOS DE APOIO AO ENSINO ..........................................................16

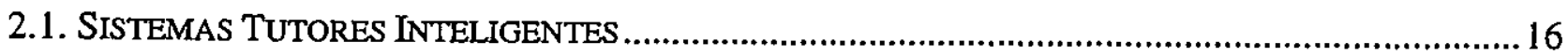

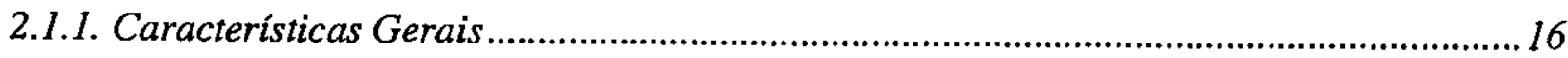

2.1.2. Arquitetura de Sistemas Tutores Inteligentes ............................................................ 19

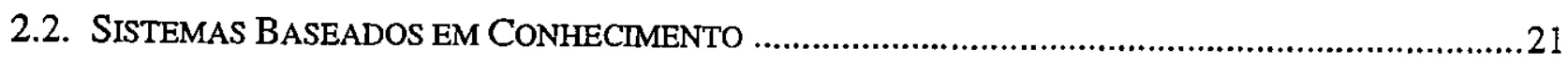

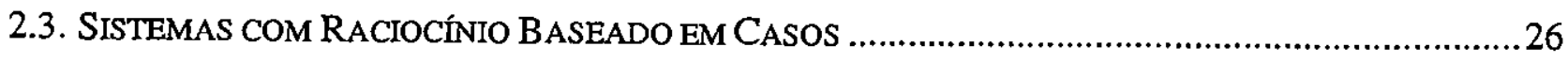

2.3.1. Requisitos de um Sistema de Raciocínio Baseado em Casos ..........................................29

2.3.2. Tipos de Sistemas de Raciocínio Baseado em Casos..........................................................31

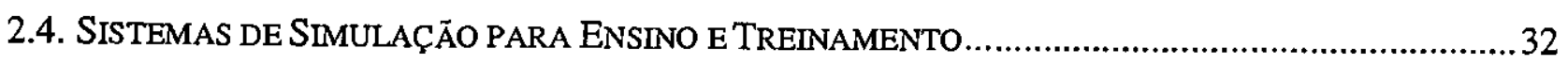

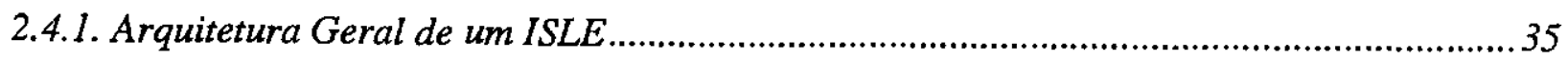

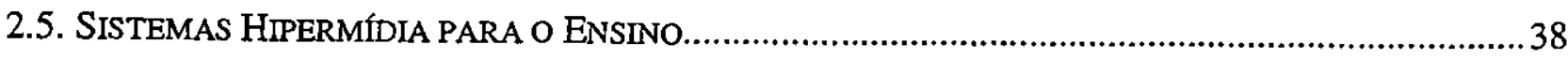

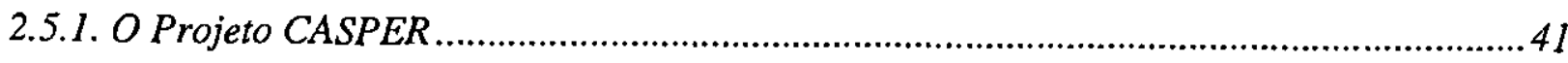

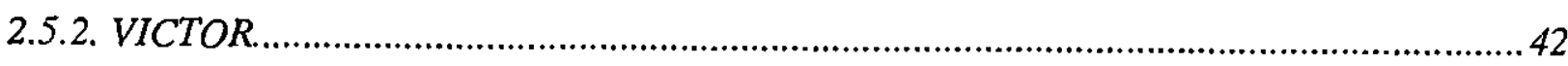

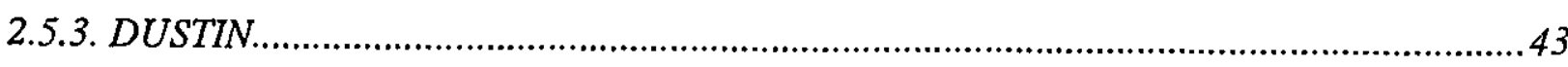

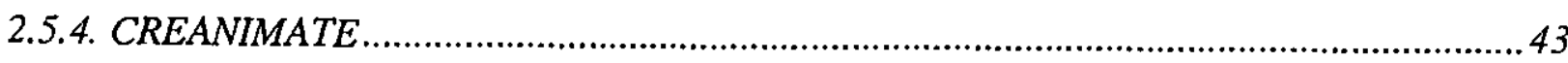

3. SIATE - SISTEMA INTELIGENTE DE APOIO AO TREINAMENTO E ENSINO............45

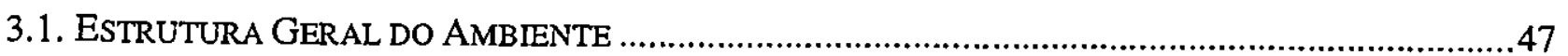

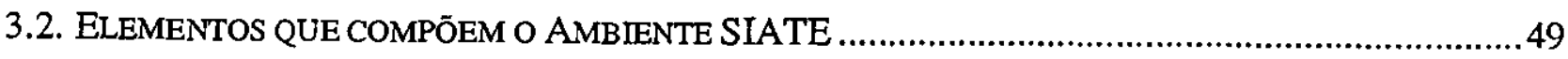

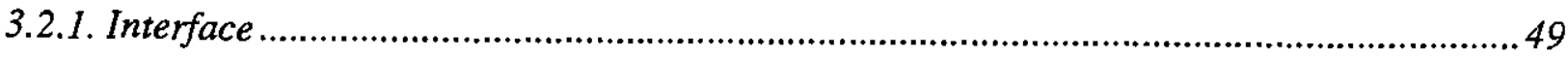

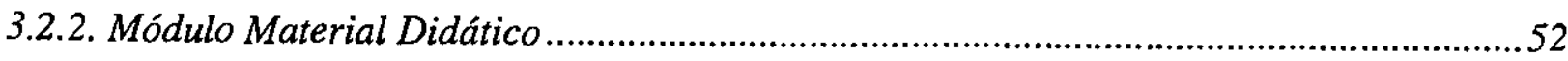

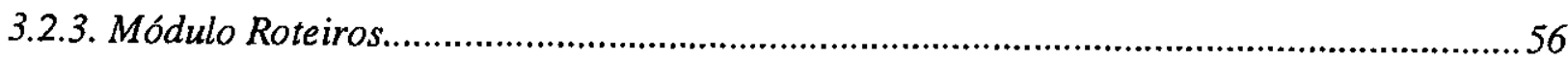

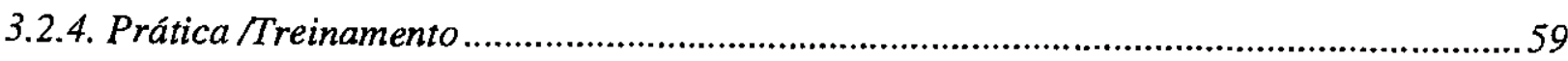

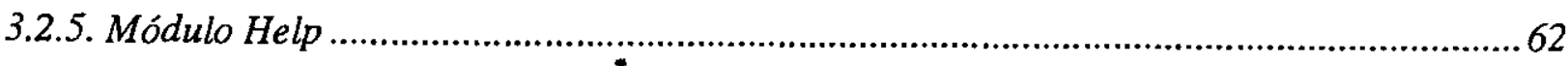

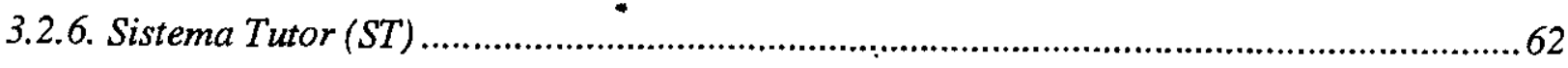

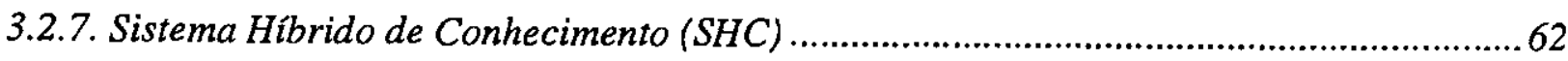

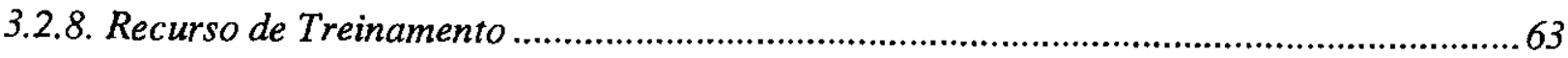




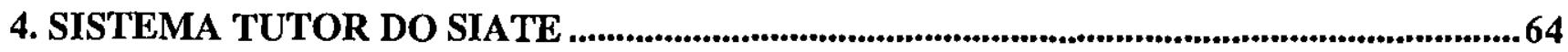

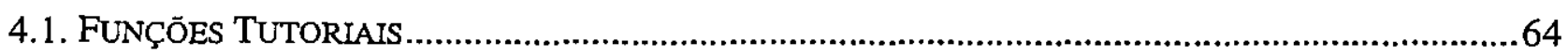

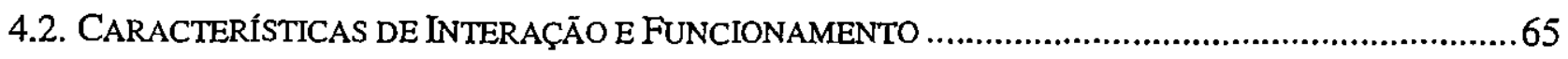

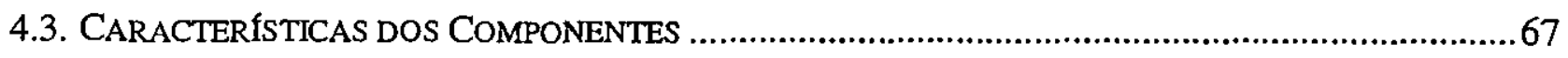

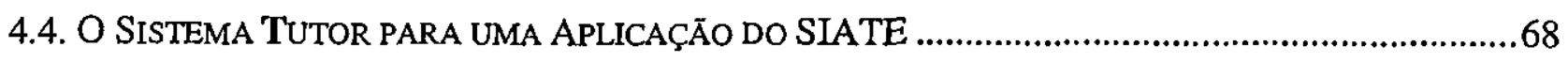

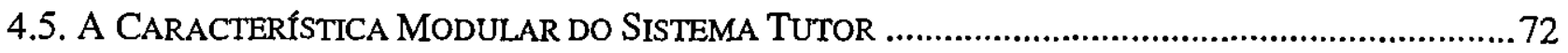

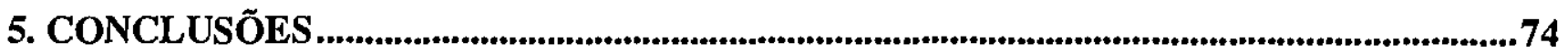

REFERÊNCIAS BIBLIOGRÁFICAS................................................................................76

APÊNDICE 1 - HIPERTEXT DESIGN MODEL (HDM) .............................................................1 APÊNDICE 2 - AQUISIÇÃO DE CONHECIMENTO …...................................................... 4 


\section{Índice de Figuras}

Figura 1 - Area de Interseçāo entre os Sistemas CAI e ICAI (Nwana, 1990).......................................................... 17

Figura 2 - Arquitetura Geral de um STI (Nwana, 1990)........................................................................................... 19

Figura 3 - A localizaçäo dos SEs e SBCs dentro da IA (Rodrigues \& Monard, 1993). .................................................. 22

Figura 4 - Estrutura de um Sistema Baseado em Conhecimento (Arantes \& Rodrigues, 1994)..................................... 23

Figura 5 - Exemplo Prático de RBC (Kolodner, 1992). ........................................................................................... 28

Figura 6 - Ciclo de Raciocínio Baseado em Casos (Aamodt \& Plaza, 1994). ............................................................... 30

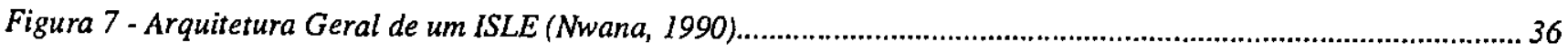

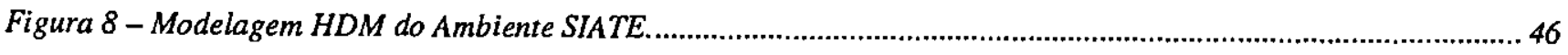

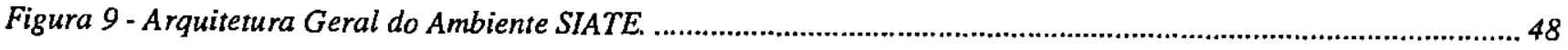

Figura 10 - Elementos que compöem o Ambiente SIATE ...................................................................................5 50

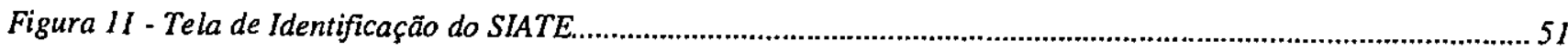

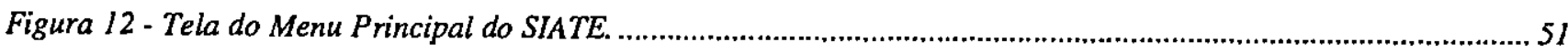

Figura 13 - Página Principal do Módulo Material Didático. ..................................................................................... 52

Figura 14- Modelagem HDM do domínio do Módulo Material Didático para um ambiente de ensino qualquer............54

Figura 15 - Página principal sobre o domínio Aquisição de Conhecimento .................................................................. 56

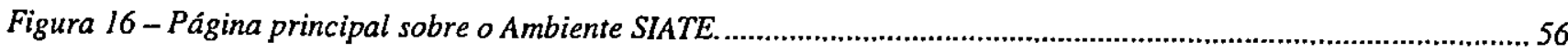

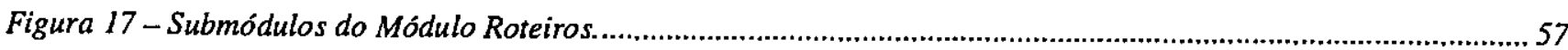

Figura 18 - Menu de Opçöes do Submódulo Seleção de Roteiros................................................................................. 58

Figura 19 - Grafo e Botöes de navegaçāo do Roteiro Aquisiçäo de Conhecimento do protótipo....................................59

Figu ra 20 - Tela Principal do Módulo PráticarTreinamento do SIATE ........................................................................6 60

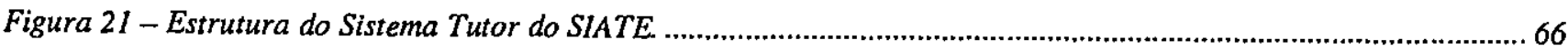

Figura 22 - Menu de Opçöes do Sistema Tutor do SIATE .....................................................................................69

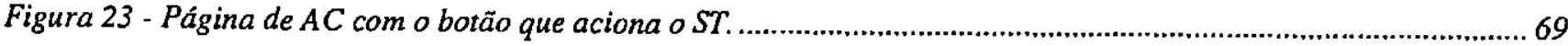

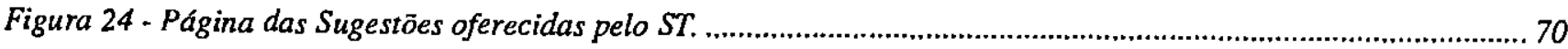

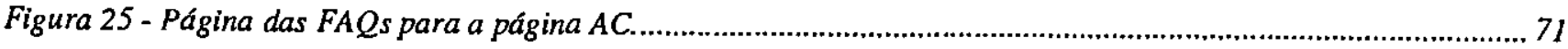

Figura 26 - Os Exemplos apresentados pelo Gerador de Exemplos. ....................................................................... 71 


\section{Índice de Tabelas}

Tabela 1 - Mapeamento de Tipos de Entidades do Esquema para Entidades da Instância SIATE. 55

Tabela 2 - Funçōes Tutoriais do Módulo Material Didático e seus Objetivos. 64

Tabela 3 - Conjuntos de informaçōes manipuladas pelo ST. 72 


\section{Introdução}

É indiscutível que os computadores têm uma importância crescente para a nossa sociedade cada vez mais complexa, e desde a invenção da escrita e da imprensa, nada tem causado tanto impacto social e estimulado tantas mudanças no mundo quanto o uso de computadores.

A visão de que o uso de computadores na educação promove o aumento da produtividade, ensinando mais a mais gente em menos tempo, é o que baseava inicialmente as investigações sobre o uso de informática na educação. Atualmente, o que se enfatiza é o provável potencial oferecido pelo uso do computador no desenvolvimento de habilidades cognitivas que proporcionam melhores meios de ensino e aprendizagem.

Os primeiros sistemas computacionais usados para o ensino são comumente conhecidos como CAI (Computer Assisted Instruction) e têm como objetivo principal a transmissão de informação (instrução) sobre determinado assunto (domínio) para o usuário/estudante. As informações são transmitidas de uma forma passiva e o sistema controla a interação. A participação do estudante se resume em selecionar alternativas. Devido à pouca capacidade cognitiva, o modelo de apresentação não pode ser alterado, o que faz o sistema agir da mesma forma com todos os estudantes (Viccari \& Moussalle, 1990). Uma das necessidades dos CAIs para realmente alcançarem seus objetivos é a flexibilidade no processo de ensino. Isto significa que o sistema precisa ser capaz de deduzir e manter um modelo detalhado do estudante, e utilizar estas informações para individualizar o ensino, modificando a apresentação do conteúdo e a estratégia de ensino, conforme necessário.

Como o intuito de aperfeiçoar o uso de informática na educação, os CAIs são alvo de várias pesquisas sobre como melhorar a performance educacional em ambientes voltados para o ensino. Eles têm sofrido várias modificações, adaptações e ganharam recursos que tornaram sua capacidade de "ensinar" mais flexível quanto ao tipo de usuário, tipo de domínio das aplicações, tipo de equipamento e ambiente de trabalho utilizados, etc. Com essa evolução, os CAIs passam a ser vistos corno ambientes propícios ao ensino, e sua gama de características educacionais aumentaram consideravelmente. 
Atualmente, pode-se classificar os tipos de CAIs como: Sistemas Tutoriais, Sistemas de Exercício e Prática, Jogos Instrucionais, Resolvedores de Problemas, Sistemas para Modelagem, Sistemas de Simulação e Sistemas de Exploração Livre.

Os Sistemas Tutoriais geralmente possuem uma estrutura sequiencial rígida, onde o sistema apresenta um tópico sobre determinado assunto (domínio) e, logo após, faz uma série de perguntas a respeito desse assunto. Mediante as respostas do estudante, o sistema "decide" que atitude tomar, ou seja: seguir adiante, propor revisão do tópico atual ou proporcionar mais informações. Esta "decisão" é considerada uma estratégia didática, que é selecionada a partir do conhecimento que o sistema acumula sobre o aluno, durante a interação entre eles (Hannafin \& Peck, 1988). Nesse tipo de CAI, o controle é inteiramente do sistema, o que de uma certa forma é considerado vantagem, por não permitir que o estudante se desvie do objetivo inicial. Mas, por outro lado, limita consideravelmente a evolução espontânea do estudante. Os tutoriais podem também incorporar técnicas de Inteligência Artificial (IA), para ter condições de decidir o que ensinar, como ensinar e quando ensinar, considerando para isto as características individuais (performance, preferências, etc.) de cada estudante e o conhecimento especialista sobre o domínio explicitado em sua base de conhecimento.

Os Sistemas de Exercício e Prática requerem respostas imediatas do estudante, mas também oferecem retorno imediato (Hannafin \& Peck, 1988). Este tipo de sistema retém inteiramente o controle da interação e proporciona o desenvolvimento de habilidades através de memorização e repetição, o que o torna cansativo rapidamente. A estratégia de ensino utilizada aqui é única: estímulo e resposta. Mesmo assim, torna-se eficaz para se alcançar treinamento, que é o objetivo principal desse tipo de sistema (Valente, 1993).

Nos Jogos Instrucionais, a estratégia de ensino utilizada para se alcançar o objetivo educacional é o desafio. Entretanto, a competição provocada por este tipo de sistema, geralmente desvia a atenção do aluno do propósito real, que é a aquisição de algum conhecimento (Valente, 1993). Por outro lado, os jogos instrucionais podem ser utilizados para a criação de situações que favorecem a aprendizagem. Com isso, é relevante a participação do professor para influenciar o estudante a utilizar esse recurso para aprender sobre algum assunto específico.

Os Resolvedores de Problemas, apresentam resultados que são alcançados com base nas informações que fazem parte do seu domínio, a partir de informações oferecidas ou problemas propostos pelo estudante. O ponto forte desse tipo de sistema é poder apresentar ao estudante o 
caminho percorrido, ou seja, os mecanismos que foram utilizados para se alcançar a resposta. $O$ controle é inteiramente do sistema. Como exemplo desse tipo de sistema, podemos citar os Sistemas Baseados em Conhecimento (Arantes \& Rodrigues, 1994).

Os Sistemas para Modelagem propiciam um sistema do tipo Resolvedor de Problemas, com a diferença que, na modelagem, quem constrói a solução dentro das regras e limitações do sistema é o estudante. A estratégia utilizada nesse tipo de sistema é incentivar o aluno a obter uma representação formal e precisa do problema (Valente, 1993). Em geral, eles oferecem a possibilidade de verificar a corretude da solução construída, através do uso de simulação. O estudante pode tirar conclusões sobre o resultado e redefinir o modelo até que uma solução satisfatória seja alcançada.

O Sistema para Simulação tem como objetivo principal se aproximar (virtualmente) o máximo possível da representação de uma porção física do mundo real e das possíveis situações desse mundo. Permite a exploração de situações que poderiam ser caras, difíceis e principalmente perigosas em condições normais, como por exemplo: simuladores de vôo, simuladores de experiências químicas, etc. Essa característica de sistemas de simulação indica um controle misto da interação, pois o aluno pode dispor de vários níveis de interação dependendo do domínio da simulação, mas sempre dentro das regras impostas pelo sistema (Jong, 1991). Podem ser utilizados juntamente com a modelagem para tentar validar modelos propostos.

Nos Sistemas de Exploração Livre o estudante navega em um documento, onde as informações estão organizadas sob a forma de páginas, conectadas através de "links" (elos de ligação). Aqui, o controle é inteiramente do usuário que decide qual caminho deseja seguir, quando voltar ou pular adiante, quando seguir um determinado caminho e quando evitar as distrações com possíveis caminhos irrelevantes (Large, 1996). A demanda cognitiva sobre o aluno é maior porque ele deve tomar as decisões corretas para que o aprendizado ocorra de fato. A Exploração Livre permite que o aluno tenha progresso de acordo com os seus interesses e objetivos, criando um ambiente favorável para a busca de informações. Entretanto, a falta de orientação pode retardar o alcance dos objetivos e o desvio do mesmo. Um exemplo desse tipo de sistema são as aplicações hipermídia desenvolvidas para WWW (World Wide Web).

A partir dessa classificação dos sistemas computacionais voltados para o ensino, torna-se mais fácil a identificação de características educacionais ern sistemas computacionais, mais claras as vantagens e desvantagens proporcionadas por esses sistemas e o direcionamento de estudos e pesquisas sobre os recursos oferecidos por eles. O caminho a ser seguido por pesquisas ou estudos 
que podem ser efetuados a partir dessas informações variam de acordo com o domínio e o público alvo em questão, ou seja, da aplicação que se deseja desenvolver.

Entre as pesquisas importantes realizadas atualmente, encontram-se aquelas que buscam ferramentas para a organização e a recuperação das informações armazenadas através de metodologias não convencionais (não lineares). Os sistemas hipermídia retratam este tipo de ferramenta. Hipermídia é de grande interesse em educação e treinamento por várias razões, mas particularmente pelo fato de suportarem um modelo de aprendizagem que contrasta com o programa tradicional de ensino e com o modelo de sistemas tutores. Ao mesmo tempo, avanços em armazenamento e tecnologia de áudio e vídeo, estão tomando possível o acesso rápido e barato às grandes bases de informação multimídia (Hammond, 1989).

Entre as técnicas de aprendizado atuais, destaca-se o treinamento, onde a teoria aprendida é colocada em prática fazendo com que a assimilação se torne mais rápida e eficiente. Uma forma de treinamento através da qual vêm-se obtendo bons resultados é a simulação, onde os mais variados ambientes têm as possíveis situações simuladas, de modo que o estudante possa, através de informações concretas, aprender praticando. Quando o estudante já possui algum conhecimento do problema a ser simulado, ele não encontra problemas em identificar os recursos e as características que o sistema tem em comum com o mundo real. Porém, quando não existe este conhecimento por parte do estudante, o sistema pode ser "ineficiente", caso não fomeça nenhum tipo de monitoramento ou explicação durante a simulação.

Assim, para se obter um ambiente de aprendizado adequado é necessário que haja recursos como: controle de características dos estudantes, facilidades de navegação, facilidades para interação entre o usuário e o sistema, formas de direcionar o ensino de acordo com o comportamento do usuário (técnicas didáticas e pedagógicas), etc. Duas fontes de recursos para enriquecer tais ambientes são: Hipermídia e Inteligência Artificial.

A utilização de recursos hipermídia em ambientes de ensino oferece uma maior flexibilidade de uso e uma melhor apresentação das informações aos usuários. E, além disso, também os estimula a aprender, devido a recursos áudios-visuais normalmente disponíveis.

Técnicas de Inteligência Artificial, por outro lado, aumentam o poder de simulações e aplicaçōes hipermídia, capacitando-as a "decidir" sobre que informaçōes apresentar a seguir e como e quando apresentá-las, baseando-se, por exemplo, em características do usuário (comportamento do usuário durante o aprendizado), em conhecimentos especialistas sobre o domínio da aplicação, em 
inferências (feitas pelo sistema) obtidas a partir desse conhecimento especialista, em casos passados, etc. Essas técnicas e tipos de informações são utilizados, por exemplo, em sistemas conhecidos como Sistemas Baseados em Conhecimento.

Este trabalho propõe um ambiente denominado SIATE (Sistema Inteligente de Apoio ao Treinamento e Ensino), que integra características de ambientes de Prática/Treinamento, Hipermídia, Sistema Tutor (ST) e Sistema Híbrido de Conhecimento (SHC) voltado para o ensino e, que tem como característica marcante a liberdade, por parte do estudante, de explorar um domínio qualquer, podendo recorrer quando necessário, ao auxílio de um ST e de um SHC com conhecimento especialista nesse domínio.

O projeto SIATE é constituído de dois subprojetos. O primeiro deles corresponde ao projeto e desenvolvimento de um Sistema Tutor que auxiliará o estudante, enquanto ele estiver navegando em um hiperdocumento, através da disponibilização de informações sobre um domínio específico, e também, ao desenvolvimento dos recursos hipermídia disponíveis no ambiente SIATE. O segundo subprojeto corresponde ao projeto e desenvolvimento de um Sistema Híbrido de Conhecimento, sobre o mesmo domínio, que servirá como fonte de informação ao estudante, que o acionará quando necessitarem de informações especialistas para solucionarem algum tipo de problema. Este último subprojeto é desenvolvido por outro trabalho de mestrado (Pugliesi, 1997).

Foi selecionado como domínio para um protótipo de aplicação do SIATE o tópico Aquisição de Conhecimento para Sistemas Inteligentes, onde são abrangidos os subtópicos de Aquisição de Conhecimento Explícito e Implícito. Esta seleção se deve ao "gargalo" existente no processo de aquisição de conhecimento especialista. Com isso, a função principal dessa aplicação do SIATE é auxiliar engenheiros de conhecimento, público alvo do ambiente, em aprender como efetuar aquisição de conhecimento de forma correta e eficiente.

Esta dissertação está organizada em cinco capítulos, de forma que o Capítulo 2 apresenta um estudo detalhado sobre alguns sistemas voltados para o ensino, com suas características relevantes, vantagens e desvantagens de utilização, implementação e funcionamento.

No Capítulo 3 é apresentada a proposta do Ambiente SIATE, com a descrição de cada um dos módulos e dos componentes, que auxiliam estes módulos, que são parte integrante do ambiente.

No Capítulo 4 são descritas as características do Sistema Tutor do SIATE, a especificação dos seus submódulos e funções tutoriais disponíveis no Módulo Material Didático e Módulo Roteiros. 
O Capítulo 5 apresenta as conclusões e finalmente são apresentadas as Referências Bibliográficas.

Dois apêndices são apresentados. No Apêndice 1 encontram-se algumas definições e características do HDM (Hipertext Design Model), modelo que foi utilizado para a modelagem do domínio do Módulo Material Didático, e no Apêndice 2 é apresentado o domínio selecionado para o protótipo de aplicação do SIATE que é Aquisição de Conhecimento para Sistemas Inteligentes. 


\section{Sistemas e Recursos de Apoio ao Ensino}

Será apresentada, nesse capítulo, uma revisão de alguns tipos de sistemas e recursos que têm sido bastante utilizados no desenvolvimento de sofwares educacionais. Serão mostradas as principais características de cada um e quais as vantagens e desvantagens de utilizá-los para fins educacionais. Inicialmente, serão apresentados os Sistemas Tutores Inteligentes que são sistemas voltados para o ensino e que contam com o apoio de técnicas de Inteligência Artificial.

\subsection{Sistemas Tutores Inteligentes}

Os STIs surgiram a partir de uma interseção de três áreas de pesquisa (Figura 1) com o objetivo principal de desenvolver sistemas computadorizados eficientes para o ensino: Ciência da Computação (Inteligência Artificial - IA), Psicologia Cognitiva e Metodologia de Ensino. Enquanto a Ciência da Computação fornece técnicas para a representação e manipulação do conhecimento envolvido, a Psicologia Cognitiva traz modelos sobre a forma de como o indivíduo constrói o conhecimento na interação organismo/meio-ambiente físico e social, e a Metodologia de Ensino estuda as melhores formas de ensino/aprendizagem.

STI é um programa de computador destinado ao ensino, que incorpora técnicas de IA . permitindo que o sistema saiba o quê ensinar, a quem ensinar, e como isto deve ser feito.

\subsubsection{Características Gerais}

Tendo em vista o atual desenvolvimento da Ciência da Computação, no que se refere às teorias e técnicas de IA (representação do conhecimento, mecanismos de inferência, busca), hardware (maior velocidade de processamento e memória) e da ciência cognitiva, é perfeitamente viável pensar no computador como um tutor interativo e inteligente, isto é, que percebe a 
intervenção do estudante, aprende a dialogar com ele, o orienta, diagnostica as suas deficiências, e obtém informações de forma amigável e coerente.

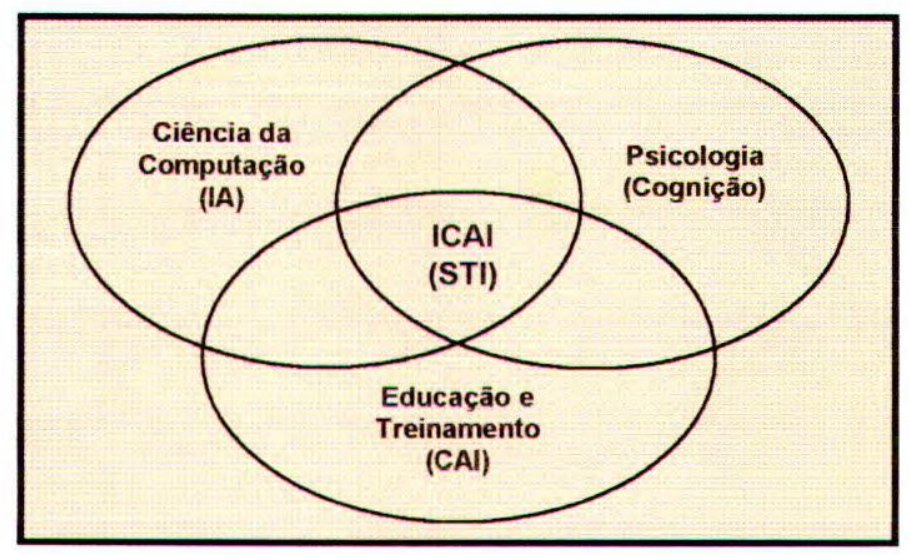

Figura 1 - Área de Interseção entre os Sistemas CAI e ICAI (Nwana, 1990).

Algumas das principais características de um STI, que o diferenciam dos sistemas CAI são (Nwana, 1990):

- o STI deve assegurar uma clara articulação de conhecimento num domínio limitado, isto é, uma representação explícita e aprofundada do domínio;

- o STI deve ter um modelo de performance do estudante, que é mantido dinamicamente, e usado para guiar a "aula";

- o projetista (ou especialista no assunto) deve definir o conhecimento e as regras de inferência, mas não a seqüência da aula, que deve ser determinada pelo sistema;

- o STI deve prover diagnóstico detalhado de erros, ao invés de mostrar simplesmente a resposta certa;

- o estudante deve poder questionar um STI, além de responder as questões formuladas por ele. 
A meta dos STIs é ensinar um determinado conhecimento, envolvendo diretamente um diálogo máquina (tutor) - estudante. Comparando um STI com um tutor humano, nota-se uma necessidade de dupla checagem por parte do tutor, ou seja, mais do que um típico locutor, o tutor deve verificar e inspecionar o conhecimento do estudante para descobrir, ele compreende ou não as informações fornecidas pelo sistema (Woolf \& McDonald, 1984).

Um STI ideal deveria, assim, possuir as seguintes características gerais (Viccari \& Moussalle, 1990):

- ser flexível em todos os níveis (arquitetura, controle, comunicação, adaptação ao estudante);

- possibilitar e incentivar a exploração do assunto em questão pelo estudante;

- possuir vários métodos de ensino para apresentação do assunto;

- dominar, o máximo possível, o assunto que ensina;

- ter meta-conhecimento para resolver situações não previstas nas regras que descrevem o conhecimento do tutor;

- operar conforme o(s) método(s) de ensino adotados (caráter tutorial);

- ter mecanismos inteligentes para a depuração e a orientação na detecção de falhas;

- possuir mecanismos que permitam a simulação automática e resolução interativa dos problemas;

- ter capacidade de aprendizagem visando, pelo menos, a adequação ao estilo do estudante;

- ter mecanismos que descrevam o raciocínio que o estudante e o tutor utilizam ao explorar um determinado assunto;

- ter capacidade para reconstruir estados passados.

Através da utilização de vários métodos e recursos oferecidos pela IA, tem-se tentado dotar um sistema tutor com algumas destas características. Cada uma delas já constitui uma tarefa bastante complexa. Contar com todas elas num único sistema compreende muito mais complexidade, trabalho e pesquisas. 


\subsubsection{Arquitetura de Sistemas Tutores Inteligentes}

Um STI possui, em geral, cinco módulos (Figura 2):

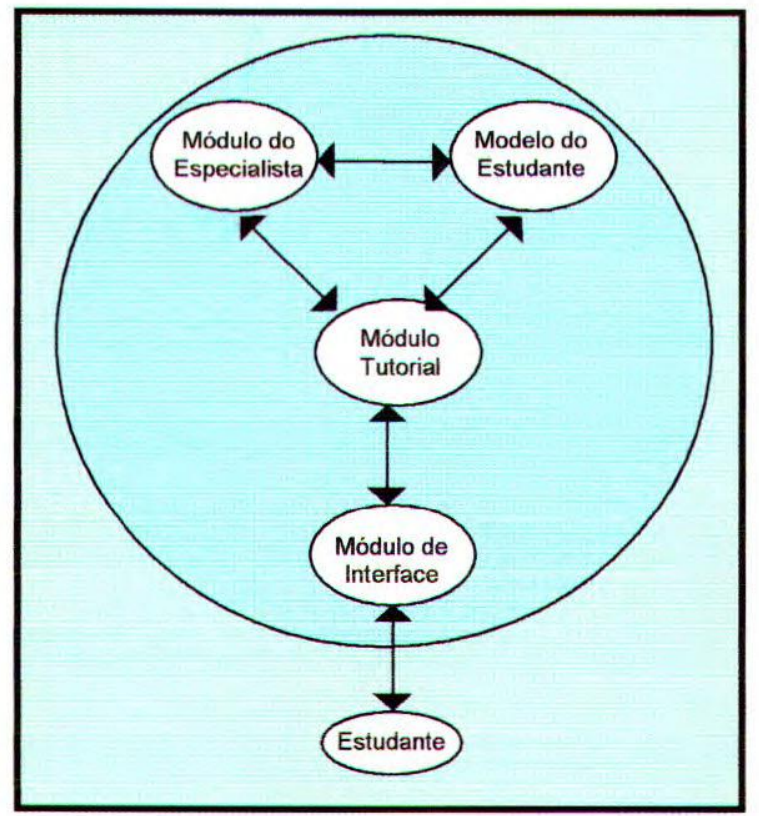

Figura 2 - Arquitetura Geral de um STI (Nwana, 1990).

- Módulo Especialista (módulo do domínio);

- Modelo do Estudante;

- Módulo Tutorial;

- Módulo de Interface com o Usuário.

O Módulo Especialista compreende os fatos e as regras de um domínio (assunto) particular que será pesquisado pelo estudante, isto é, o conhecimento do especialista sobre um domínio específico. Este módulo cumpre duas funções: primeiro, serve como fonte do conhecimento a ser apresentado ao estudante, o que inclui fonte para geração do material, geração de perguntas, explicações e respostas; segundo, fornece um padrão para avaliar o desempenho do aluno. Heurísticas inteligentes no módulo do especialista oferecem uma maior flexibilidade para interpretar 
as respostas não tradicionais de alguns estudantes, ou seja, respostas que são expressas de maneira fundamentalmente diferentes. Isto aumenta a habilidade do sistema em expressar seu próprio conhecimento, tornando-o capaz de explicar o raciocínio usado para a resolução de problemas. Os principais problemas encontrados são: o processo de aquisição de conhecimento, via especialista, e a representação deste conhecimento.

O Modelo do Estudante contém a representação do conhecimento e do desempenho de um estudante individual, servindo de subsídio para o sistema decidir o quê e como deve ensinar, e em que nível de conhecimento o estudante se encontra. O conhecimento retido por este módulo pode ser alterado durante o treinamento, dependendo da performance do estudante. Também é utilizado para detectar o processo de raciocínio utilizado pelo estudante em particular. Este módulo tem por objetivo auxiliar no diagnóstico, correção e prevenção de erros do estudante, e é considerado o módulo principal, o núcleo de qualquer STI. Os principais problemas encontrados estão relacionados com o quê representar e como representar. Modelagem de estudante é o nome geral dado à tarefa de reunir informações relevantes sobre um estudante de maneira individual, que são utilizadas para guiar o procedimento de um STI. Por enquanto, ainda não existem técnicas estabelecidas para o modelos de estudante, o que existe é uma coleção de protótipos, e não está claro o quanto eles podem ser generalizados além de alguns poucos domínios reincidentes na literatura, como no ensino de matemática, por exemplo, (Vassileva, 1990).

O Módulo Tutorial é a parte de um sistema tutor que cria e regula as interações de aprendizagem com o estudante, ou seja, contém as estratégias, regras e processos que govemam a interação do sistema com o estudante (decide qual material apresentar e quais questões ou exemplos sugerir). Ele utiliza do conhecimento sobre o estudante, obtido do modelo do estudante, e de sua própria estrutura tutorial, para decidir quais atividades pedagógicas serão propostas ao aluno. Em algumas arquiteturas, este módulo é chamado de módulo pedagógico (Nwana, 1990). O principal problema que enfrenta é o controle da iniciativa, ou seja, a iniciativa deve ser sempre do sistema, do estudante ou mista (sistema e estudante) (Woolf \& McDonald, 1984).

O Módulo de Interface com o usuário é o componente de comunicação do sistema que controla sua interação com o estudante. É responsável por traduzir a representação intema do sistema para uma linguagem de interface que é compreensível para o estudante e, no sentido inverso, buscar respostas do sistema para as intervenções do usuário. Deve acomodar os objetivos do sistema e do estudante, podendo assim, enriquecer esta interação com outros meios de comunicação (som, 
imagem), além de fornecer meios para que seja possível ao professor e/ou especialista alterar/atualizar o sistema. A interface tem que ser construída de uma maneira amigável, simples e que estimule o estudante. Quanto mais um estudante se sentir inserido no seu ambiente de aprendizagem, mais rica será a sua experiência. Esta inserção pode ser facilitada através da interaçāo com uma interface de múltiplos meios, ou seja, vários recursos para comunicação. A escolha do recurso para comunicação entre usuário e sistema, mais adequado ao tópico a ser ensinado e a eficácia da comunicação são, portanto, um problema relevante (Nwana, 1990).

Pode-se classificar um STI como um Sistema Baseado em Conhecimento (SBC), uma vez que, além do conhecimento sobre as características de cada usuário, um STI deve possuir também o conhecimento especialista sobre determinado domínio e saber obter resultados a partir desse conhecimento. As características gerais de um SBC são apresentadas a seguir.

\subsection{Sistemas Baseados em Conhecimento}

Um Sistema Baseado em Conhecimento (SBC) é um tipo de programa de Inteligência Artificial que faz uso intenso de conhecimento especializado, para tentar solucionar problemas de alguma forma, que seja o mais próxima possível da forma que um especialista humano utilizaria. São programas que manipulam conhecimento e informações de forma inteligente (Arantes \& Rodrigues, 1994).

O Professor Edward Feigenbaum da Stanford University, um dos pioneiros da tecnologia de SBCs, definiu um SBC como sendo um programa de computador inteligente que usa conhecimento e procedimentos de inferência para resolver problemas que são suficientemente difíceis e requerem um especialista humano para que se obtenha soluções relevantes. Isto é, um SBC é um sistema de computador que emula a habilidade de tomada de decisão de um especialista humano. Esses sistemas podem ser classificados como Sistemas Especialistas (SEs) em situações cujo desenvolvimento é voltado para aplicações em que o conhecimento a ser manipulado restringe-se a um domínio específico e conta com um alto grau de especialidade, possibilitando resultados mais precisos (Figura 3).

Por assemelhar-se a especialistas humanos na resolução de problemas pertencentes a uma determinada área de conhecimento, os SBCs devem ser capazes de (Arantes \& Rodrigues, 1994): 
- interagir com o usuário fazendo-lhe perguntas, e desta forma reunir as informações de que necessita;

- desenvolver uma linha de raciocínio a partir dessas informações adquiridas e do conhecimento nele embutido, de forma a encontrar soluções satisfatórias;

- explicar ao usuário, no mínimo, por que faz determinadas perguntas e como chega às suas conclusões, caso seja questionado;

- lidar com regras e informações imprecisas. Esta é uma característica que, entre outras, o diferencia dos sistemas convencionais, os quais são capazes de manipular somente dados e regras determinísticas.

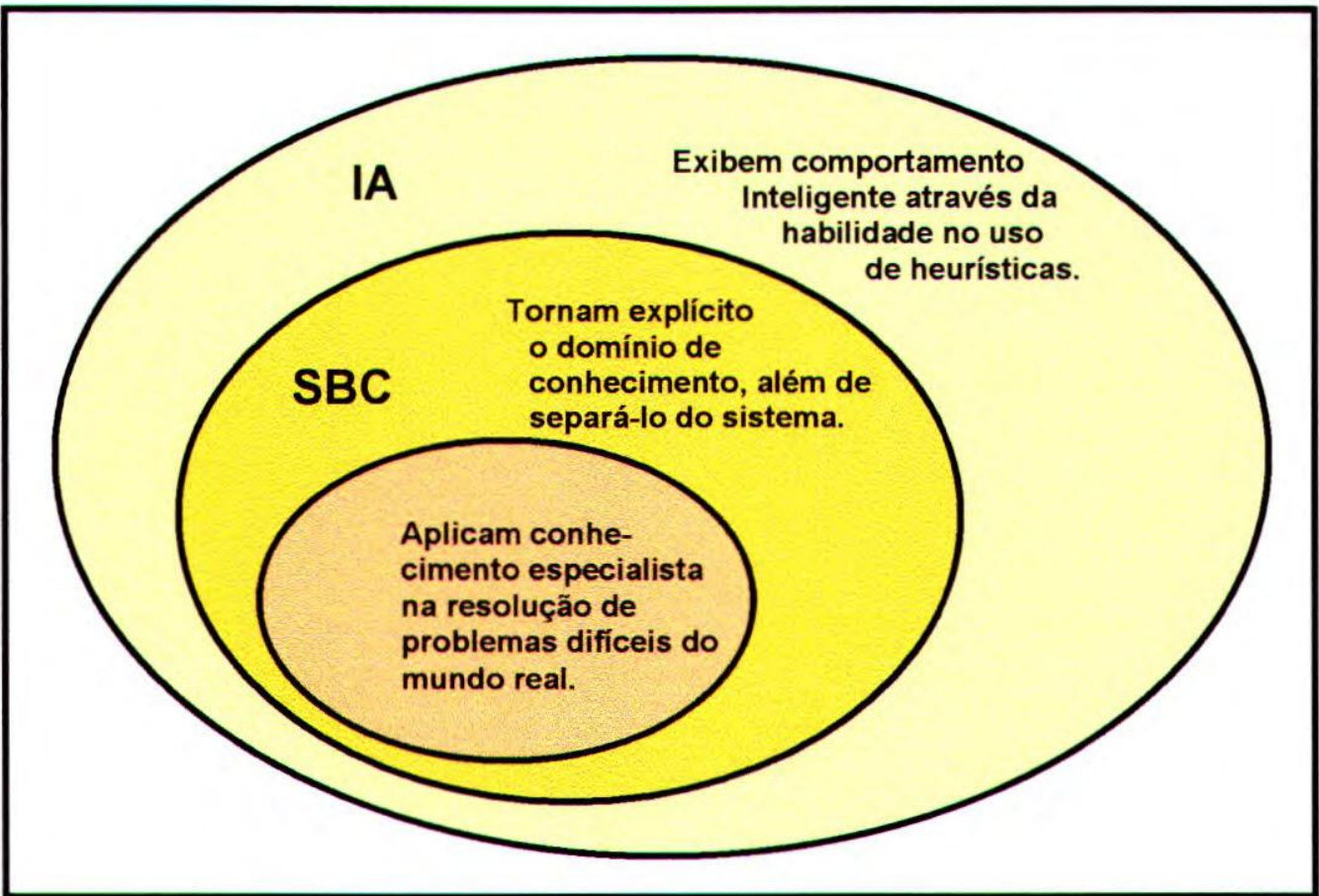

Figura 3 - A localização dos SEs e SBCs dentro da LA (Rodrigues \& Monard, 1993).

Em geral a estrutura de um SBC constitui-se de (Figura 4):

Núcleo de Sistema Baseado em Conhecimento

Base de Conhecimento 


\section{A) Núcleo de Sistema Baseado em Conhecimento}

O Núcleo de Sistema Baseado em Conhecimento (NSBC) é o módulo onde são realizadas as principais atividades do sistema, que incluem:

- interação com o usuário ou equipamentos externos;

- processamento do conhecimento utilizando alguma linha de raciocínio;

- justificação ou explicação das conclusões obtidas a partir deste raciocínio.

É composto basicamente de três subsistemas interdependentes, cada qual com funções específicas. São eles: Módulo Coletor de Dados, Motor de Inferência e Módulo de Explicações.

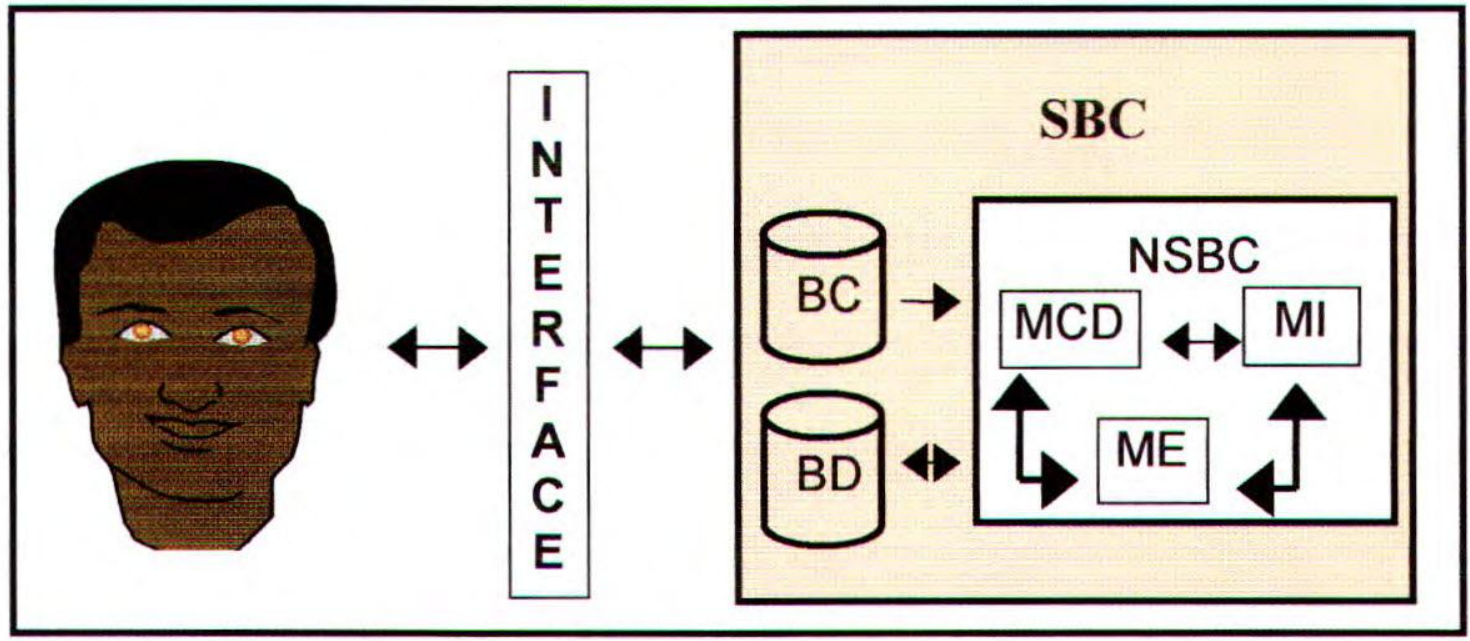

Figura 4 - Estrutura de um Sistema Baseado em Conhecimento (Arantes \& Rodrigues, 1994).

Enquanto executa suas funções, o NSBC interage com uma Base de Dados (BD), onde grava e acessa os dados temporários obtidos no processo de inferência. Além disso, utiliza uma Base de Conhecimento (BC), na qual é representado, todo o conhecimento extraído de um ou mais especialistas e em alguns casos, heurísticas para manipulá-lo

Passaremos agora a uma explicação com mais detalhes sobre cada módulo no NSBC. 
O Módulo Coletor de Dados (MCD) é o módulo do NSBC responsável pela interação com o usuário, obtendo informações através de perguntas. Geraimente quando ativado pelo Motor de Inferência, o MCD faz perguntas necessárias e valida as respostas baseando-se em funções de crítica pré-estabelecidas na Base de Conhecimento. Tais funções verificam a corretude das respostas, elas forem válidas, o MCD as transfere ao Motor de Inferência, para que o mesmo possa continuar a desenvolver seu raciocínio.

O Motor de Inferência (MD) é o módulo do NSBC responsável pelo desenvolvimento de uma linha de raciocínio que permite que se tire conclusões a partir de um determinado problema. Para tanto, o MI dispõe:

- do conhecimento de um especialista, o qual está armazenado sob a forma de algum tipo de representação (regras, frames, redes semânticas, etc.) na Base de Conhecimento;

- das informações do problema em estudo, obtidas pelo Módulo Coletor de Dados através de perguntas feitas ao usuário;

- dos dados temporários gravados na Base de Dados durante a execução do sistema;

- de método(s) de inferência que permitem a ele manipular todos os itens acima, de forma a conseguir chegar a uma solução satisfatória dado um problema. Podem ser utilizados métodos importantes como Backward Chaining ou Forward Chaining (Rich \& Knight, 1993).

Após a exposição das conclusões obtidas pelo MI, o usuário poderá perguntar qual a linha de raciocínio desenvolvida até se chegar às mesmas. Se assim acontecer, o Módulo de Explicações é ativado e explica todo o processo.

$>$ O Módulo de Explicações (ME) é o modulo do NSBC responsável por esclarecer as dúvidas do usuário, durante ou após o processamento do raciocínio.

O ME pode fornecer três tipos de explicações: 
- POR QUE: enquanto busca as soluções para o problema em questão, o Motor de Inferência necessita de algumas informações. O Módulo Coletor de Dados é então ativado de modo a questionar o usuário. Se o mesmo perguntar o porquê da pergunta, o Módulo de Explicações é então ativado pelo Módulo Coletor de Dados, e justifica a necessidade da pergunta.

- COMO: ao final do processo de inferências, o Motor de Inferência chega às suas conclusões e as expõe ao usuário, se for requisitado. , além disso, o usuário quiser saber como as conclusões foram obtidas, o Módulo de Explicações é ativado, e fornece toda a árvore de prova do processo. Esta árvore contém todas as provas intermediárias e relevantes realizadas durante o desenvolvimento do raciocínio. O Módulo de Explicações fornece as conclusões tiradas a partir destas provas até chegar à solução final.

- WHAT_IF: caso o usuário queira saber qual seria o resultado obtido se uma ou mais informações fossem modificadas, então poderá perguntar what_if ao final da execução do sistema. Se assim acontecer, o Modulo de Explicações pergunta quais as condições a serem substituídas, apaga da Base de Dados antigas informações referentes a tais condições e ativar o Motor de Inferência, que reiniciar o processo de inferências. Assim, novas conclusões serão obtidas.

\section{B) Base de Conhecimento}

A Base de Conhecimento $(\mathrm{BC})$ é onde fica representado todo o conhecimento especialista no domínio selecionado.

A forma de representação deve ser compatível com a forma de manipulação do NSBC. Ou seja, o conhecimento é representado usando-se umas das linguagens de representação de conhecimento, como por exemplo: frames, regras de produção, redes semânticas, etc. Quando utilizamos uma combinação de técnicas diferentes para representar o conhecimento, dizemos que o SBC é um Sistema Híbrido de Conhecimento. 


\section{C) Base de Dados}

A Base de Dados (BD), consiste da área de trabalho de um SBC, onde podem ser gravadas todas as conclusões intermediárias e provas realizadas durante a execução dos programas. Podemos dizer que a $\mathrm{BD}$ funciona como a "memória" do sistema e, portanto sua utilização traz duas vantagens:

- permite fornecer ao usuário toda a árvore de prova correspondente às conclusões obtidas;

- não torna necessária a repetição da mesma pergunta ou de uma mesma prova.

A Interface é o meio através do qual o sistema consegue comunicar-se com o usuário e viceversa. Deve conter características que tornem a comunicação o mais simples e o mais amigável possível. Para que isto aconteça, podem ser utilizados recursos como: áudio, vídeo e linguagem natural, na tentativa de obter um conjunto rico de alternativas de apresentação e captação de informação.

Existem vários esquemas e linguagens de representação do conhecimento do domínio em um SBC, como foi dito anteriormente. Pode-se também representar o conhecimento através de casos, que são formas de armazenamento de experiências passadas utilizadas pelos Sistemas de Raciocínio Baseado em Casos apresentado a seguir.

\subsection{Sistemas com Raciocínio Baseado em Casos}

Psicólogos têm observado que as pessoas usam raciocínio baseado em casós passados, tanto para resolver problemas, como para tomada de decisão em uma série de circunstâncias. Da mesma forma que as pessoas têm facilidade para raciocinar através de analogias (inclusive em situações que estão tratando com informações incertas ou desconhecidas, onde um caso análogo auxilia a 
refletir como determinadas variáveis afetaram a solução no passado) as pessoas apresentam dificuldade para lembrar os conjuntos de casos mais apropriados e, adicionalmente, nem sempre conseguem ter acesso à informação correta quando existe muita informação para ser lembrada. Um outro aspecto é que novatos em determinado assunto têm dois problemas em fazer boas analogias: primeiro, não possuem experiência passada suficiente e necessária para tomar uma boa decisão baseada em analogias. Segundo, eles não têm experiência suficiente para saber quais são os aspectos principais e as partes relevantes que deverão ser melhor focalizadas, ou seja, seu critério de julgamento de similaridade de um caso é deficiente.

Raciocínio Baseado em Casos (RBC) é um paradigma de Inteligência Artificial que, em essência, busca utilizar uma experiência prévia para entender e resolver um problema novo. De um modo geral, a utilização da experiência prévia é comum no dia a dia das pessoas na resolução de diversos tipos de problemas (Kass, 1994).

Segundo (Aamodt \& Plaza, 1994), RBC é um paradigma de resolução de problemas que em muitos sentidos é fundamentalmente diferente de outras abordagens de IA. Ao invés de contar apenas com conhecimento geral do domínio de problemas, ou fazer associações junto às relações generalizadas entre descritores de problemas e conclusões, RBC utiliza o conhecimento específico de experiências anteriores e situações concretas do problema (casos). Um problema novo é solucionado procurando-se por um caso similar e reutilizando-o na nova situação-problema. Uma segunda diferença importante é que RBC é também uma abordagem para aprendizado incremental, desde que uma nova experiência possa ser guardada toda vez que um problema tenha sido resolvido, tornando-o imediatamente disponível para problemas futuros.

Em IA, os problemas na elaboração de sistemas que procuram utilizar a experiência são basicamente dois: o de se saber como armazenar essa experiência de tal forma que ela possa ser recuperada, apropriadamente, no futuro, e o de se conseguir mapear esta experiência prévia no problema atual. Em RBC, a forma para representar e armazenar a experiência é através de "casos", onde são guardados todos os atributos e as características relevantes de cada experiência passada. A Figura 5 mostra um exemplo prático de RBC.

Neste exemplo, o anfitrião hipotético está empregando RBC para planejar a refeição. A lembrança do caso é usada para:

- sugerir um meio de resolver o novo problema (sugerir o prato principal); 
- sugerir um meio de adaptar a solução naquilo que ela não se ajusta à situação corrente (substituir produtos);

- avisar possíveis falhas (Anne não come qualquer peixe);

- interpretar a situação (Por que Anne não come qualquer peixe? Será que ela come peixe-espada?).

\section{Planejando uma refeição}

Iniciando o planejamento da refeição, um anfitriäo sabe que no grupo de convidados existem várias pessoas que não comem carne vermelha nem de ave. Além disso, um deles é alérgico a leite e derivados.

O anfitrião considera também, que, sendo época de tomates, deverá usá-los como ingrediente principal na refeição. Enquanto planeja a refeição, lembra que uma vez, durante o verão serviu um prato de tomate (feito de queijo mussarela, tomates, mostarda, manjericão e pimenta, sobre uma torta) como prato principal. Estava ótimo e foi fácil de preparar. Porém, não poderá ser repetido porque um dos convidados é alérgico a leite e seus derivados (queijo mussarela).

Ele decide, então, não servir o prato de tomates e continua planejando. Como é verão, ele decide que peixe grelhado seria um bom prato principal. Mas, lembra de outro detalhe; a última vez que serviu peixe grelhado, Anne, uma das convidadas, não comeu. Isto sugere que ele não deve servir peixe grelhado. Assim, ele tenta um meio de servir peixe, de tal forma que Anne coma. Ele lembra de ter visto Anne comendo "mahi-mahi" num restaurante, e pergunta a si mesmo, que tipo de peixe ela come. $O$ peixe que eu servi estava inteiro, inclusive com cabeça. O peixe no restaurante estava em filé, lembrando mais um steak do que um peixe. Talvez eu deva servir um peixe que pareça mais com carne comum do que com peixe. Talvez peixe-espada dê certo. Peixe-espada é parecido com frango e frango eu sei que ela come. 


\subsubsection{Requisitos de um Sistema de Raciocínio Baseado em Casos}

Um sistema de RBC deve ter mecanismos para (Aamodt \& Plaza, 1994):

- representação de casos;

- indexação de casos;

- armazenamento e recuperação de casos;

- adaptação de casos;

- avaliação e reparo de casos.

Um sistema de RBC deve ter formas de armazenar a experiência passada, possibilitando a cobertura de metas e submetas que poderão surgir na resolução do problema. Tentativas com êxito serão utilizadas para propor soluções. Tentativas com falhas serão usadas para alertar falhas potenciais.

Um sistema de RBC deve ter mecanismos para indexação de casos, que permita encontrar na memoria de casos a experiência mais próxima da nova situação. Recuperação de casos é uma questão central em um sistema de RBC.

A competência para adaptação é o processo de ajustar a solução antiga de acordo com os requisitos do novo problema. Um sistema de RBC deve ter uma estratégia de adaptação das soluções de casos recuperados.

Dada uma especificação de entrada de um novo problema, um sistema de RBC deve procurar, em sua memoria de casos, por um caso preexistente que "combina" com as especificaçōes de entrada. Como regra, não se encontra um caso cujas características combinam exatamente com as especificações de entrada. Por outro lado, se for recuperado um caso "similar" à situação de entrada, o sistema (ou o usuário) deve então encontrar e modificar as porções do caso recuperado que não se ajustam à especificação de entrada. Isto é chamado de "adaptação de casos".

O resultado de uma adaptação é uma solução do problema proposto, bem como um novo caso que pode ser adicionado à memória de casos do sistema, para uso futuro. Este armazenamento de novos casos é um dos fatores que caracterizam o aprendizado de um sistema de RBC (Schank, 1990). 
A competência para avaliação é tratada em poucos sistemas de RBC. Existem situações em que os primeiros casos recuperados não sugerem uma solução particular, mas possibilitam um ponto de partida, uma proposta de solução de casos, onde a seleção do melhor caso é feita e as partes desta opção que não se ajustam à nova situação são adaptadas. Mesmo que várias adaptações sejam necessárias, em geral, isto é preferível a resolver desde o princípio todo o problema novamente. Nessas situações, quando é proposta uma solução, são apontados os possíveis problemas da solução.

A Figura 6 mostra o ciclo de um sistema de Raciocínio Baseado em Casos, onde em um nível mais alto de generalidade, um problema novo é solucionado recuperando um ou mais casos experimentados anteriormente, reutilizando o caso de uma maneira ou de outra, revisando a solução baseado na reutilização de um caso anterior e retendo a nova experiência, incorporando-a na base de casos existente.

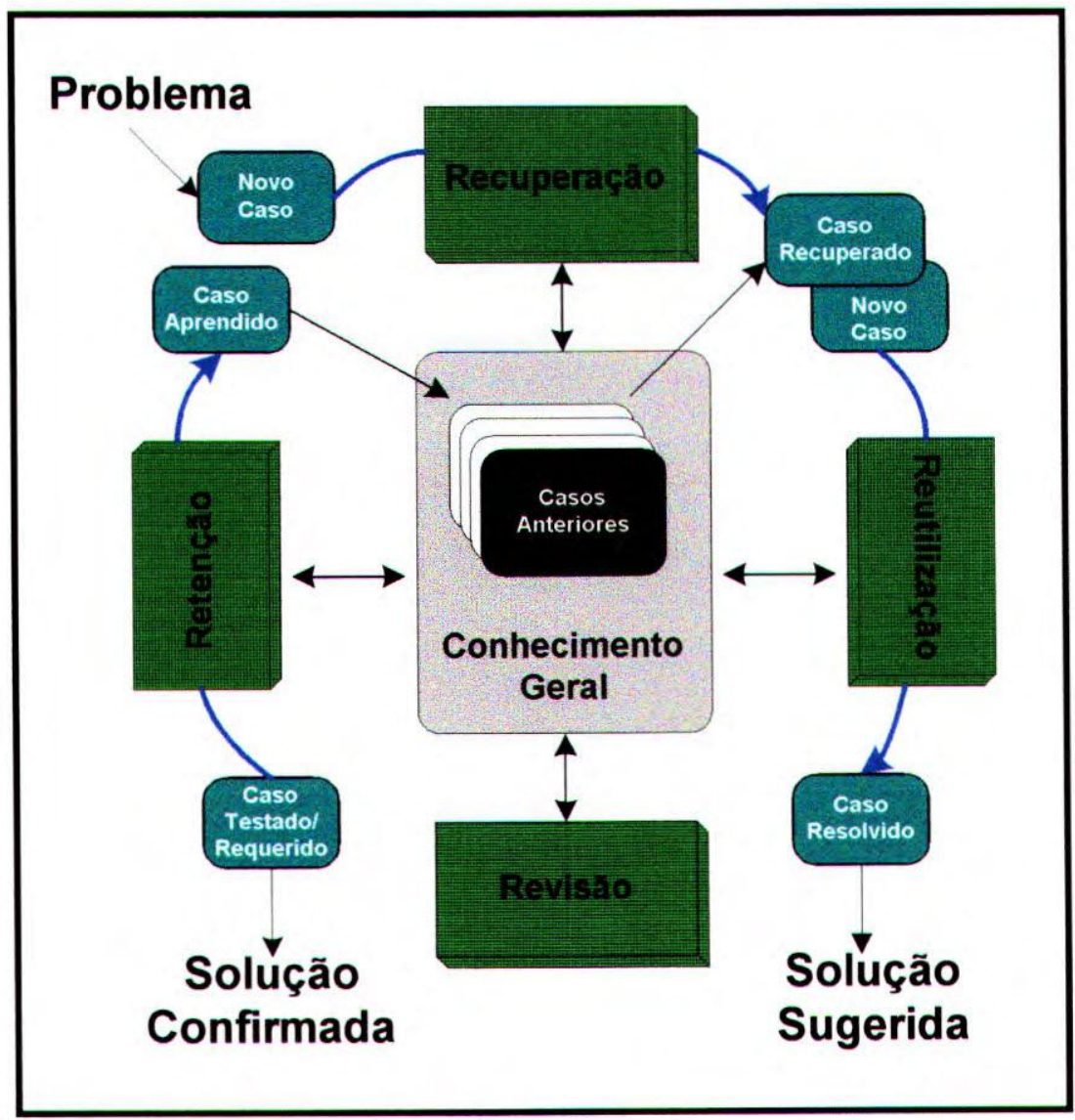

Figura 6 - Ciclo de Raciocinio Baseado em Casos (Aamodt \& Plaza, 1994). 
Observando os detalhes dessa mesma figura, pode-se identificar que: uma descrição inicial do problema define um novo caso, esse novo caso é usado para recuperar um caso de uma coleção de casos anteriores. O caso recuperado é combinado com o novo caso (através da reutilização) em um caso solucionado, isto é, uma solução proposta para o problema inicial. O processo revisar verifica se essa solução obteve sucesso, ou seja, ela é aplicada ao ambiente do mundo real ou avaliada (pelo usuário) e reformulada em caso de falha. Durante o processo reter, a experiência útil é armazenada para futura reutilização e a base de casos é atualizada por um novo caso aprendido ou pela modificação de alguns casos existentes.

O conhecimento geral normalmente faz parte desse ciclo, dando suporte para os processos de $R B C$. Esse suporte possui capacidade variável, dependendo dos tipos dos métodos de RBC. O conhecimento geral significa o conhecimento que está inteiramente ligado ao domínio como um todo, diferentemente do conhecimento específico embutido nos casos.

\title{
2.3.2. Tipos de Sistemas de Raciocínio Baseado em Casos
}

Existem dois tipos básicos de sistemas de RBC (Aamodt \& Plaza, 1994):

\begin{abstract}
A) Resolvedor de Problemas: O sistema lembra um caso passado que servirá como guia para a solução de um novo problema. No exemplo da Figura 5, a lembrança do caso sugere uma solução, que de certo modo, pode ser considerada completa. Sugere o peixe grelhado como prato principal e um modo de adaptá-lo: modificando o peixe, para um que possivelmente Anne possa comer. A lembrança do caso também alerta para possíveis falhas - existe um convidado que não come derivados de leite. Logo, não poderá ser servido nenhum prato com queijo mussarela.
\end{abstract}

B) Interpretativo: A nova situação é avaliada no contexto de uma situação antiga. Um advogado, por exemplo, usa uma série de casos passados para justificar um argumento em um caso novo. No exemplo da Figura 5, o estilo básico é o de resolvedor de problemas, mas é usada interpretação quando o anfitrião resolve fazer peixe grelhado e tenta justificar o uso de peixe-espada. 
$O$ uso de RBC no ensino visa aumentar a capacidade dos estudantes em solucionar problemas, já que o ser humano trabalha em muitos momentos, em sua vida cotidiana, com experiências passadas solucionando novos problemas em diferentes situações.

Um outro recurso muito útil para atividades de aprendizagem e treinamento é o da Simulação.

\subsection{Sistemas de Simulação para Ensino e Treinamento}

Estudos realizados sobre o uso de sistemas de simulação para ensino e treinamento apontam que no processo de aprendizado o estudante deve estar ativamente envolvido na construção e reconstrução de seus conhecimentos, e isso fatalmente se reflete no processo de ensino. Ao contrário de abordagens tradicionais de ensino, onde o estudante era visto como uma "caixa vazia" em que o conhecimento poderia ser despejado, novas abordagens acentuam o papel ativo do aprendiz e a importância do seu conhecimento prévio. Esta transformação na atitude de ensino inclui uma mudança no objetivo do aprendizado, que deixa de ser o de reproduzir o conhecimento para o de provocar a construção e a elaboração do mesmo.

Um tipo de CAI que suporta comportamento ativo do estudante é o baseado em simulação, onde estudantes exploram ativamente um domínio através da escolha de valores de entrada para um modelo de domínio.

Segundo Ton de Jong (Jong, 1991), o uso instrucional de simulação possui 4 características:

A) Presença de formalização em Modelos de Manipulação Implícito: A simulação baseada em computador prevê que um fenômeno, um processo, um sistema ou um equipamento (quando este estiver sendo simulado) estejam formalizados em um modelo e implementados como um programa de computador.

B) Presença de Objetivos de Aprendizado: A simulação normalmente é utilizada para alcançar um certo objetivo de aprendizado. Utiliza-se o termo objetivo de aprendizado quando não se pretende explicitar a diferença entre os objetivos instrucionais (originado do instrutor/professor) dos objetivos de estudantes. Objetivos de aprendizado podem ser de diferentes tipos: 
- aquisição de conhecimento sobre o assunto modelado pelo sistema, ou seja, conhecimento conceitual;

- obtenção de procedimentos específicos, ou seja, conhecimento operacional. Envolvem experiência cognitiva (resolução de problemas em um domínio específico) ou experiência com um componente psicomotor (por exemplo, aprender a pilotar um avião);

- desenvolvimento de "knowledge acquisition knowledge" (aprender como aprender), ou seja, conhecimento de processos que ocorrem enquanto se aprende com a simulação (experimentação e subprocessos).

C) Elicitacão de processos de aprendizado específicos: Esta é considerada a principal dentre as características que estão sendo apresentadas, devido ao fato de que a simulação pode ser utilizada para invocar processos de aprendizado específico, característico de aprendizado exploratório, tal como geração de hipóteses. $O$ aluno pode gerar suas hipóteses e testá-las subseqüentemente. Esta abordagem construtiva é geralmente aceita como um caminho eficiente para adquirir conhecimento, tanto conceitual como operacional.

D) Presença de atividade do estudante: O estudante pode manipular algo na simulação, por exemplo, definindo variáveis e parâmetros de entrada, selecionando variáveis de saída, dispositivos, etc. Esta característica exclui aquelas situações em que a simulação é utilizada meramente como um dispositivo de demonstração.

A importância da utilização de simulação baseada em computador para instrução se deve ao processo de aprendizado criado por ela nos estudantes.

Hebenstreit apud (Jong, 1991) ${ }^{2}$ afirma que uma simulação computadorizada cria um "mundo" entre a realidade e algum modelo abstrato dessa realidade; essa camada intermediária ajuda o estudante a atravessar o "gargalo" entre a realidade e o modelo. Outras razões para a . utilização de simulação em instrução são (Dekkers \& Donatti, 1981): 
- aumento da motivação e do aprendizado cognitivo de informações factuais;

- melhor entendimento de processos;

- melhoramento da prática de pensamento crítico;

- melhoramento da transferência de aprendizado para outras situações;

- desenvolvimento da comunicação e prática social;

- melhoramento do ambiente em sala de aula e aumento da flexibilidade do professor, que contará com um recurso didático poderoso.

O aprendizado através de simulação determina, no entanto, uma alta demanda cognitiva do estudante. Simulações podem incorporar modelos que vão de muito simples a muito complexos. Assim, o procedimento de entrada/saída associado a estes modelos também pode ser muito complexo. Aprender estes modelos e procedimentos através de simples alternativas de exploração pode ser improdutivo. Estudantes podem vir a se envolver em alternativas aleatórias, em vez de propositalmente manipular variáveis e valores de parâmetros. Existem ainda situações em que especialmente estudantes inaptos (sem um pré-conhecimento) podem obter pouco benefício da simulação. Eles podem também se acomodar, deixando de utilizar as oportunidades que o ambiente de simulação oferece. Conhecendo essas limitações, toma-se necessário um suporte à simulação para se obter um aprendizado efetivo. Algumas vezes, este suporte é oferecido por tutores humanos, mas também pode ser obtido através de um ambiente de aprendizado por computador.

Este tipo de ambiente inteligente para aprendizado é conhecido como ISLE (Intelligent Simulation Learning Environment). Existe atualmente um grande número desses ambientes, em que é oferecido aos estudantes um ambiente de simulação juntamente com alguns tipos de suporte ao aprendizado.

Com o desenvolvimento de teorias de Interação Usuário-Computador (HCI - HumanComputer Interaction), com a evolução da Tecnologia de Interfaces e ainda com os resultados obtidos por estudos de técnicas de Inteligência Artificial (IA), no que diz respeito à utilização de sistemas inteligentes como recursos educacionais, tem surgido grande interesse pelo projeto de

\footnotetext{
${ }^{2}$ (Hebenstreit, 1987) - Hebenstreit, J. Modeling and Simulation in Distance Teaching. Facilites for European open Learning. Amsterdam. North Holland, J. Whiting and D.A. Bell (eds.), 1987.
} 
ambientes de suporte à simulação que apliquem as teorias e técnicas de IA e HCI em um contexto educacional.

Sistemas que utilizam este tipo de ambiente provêm um maior desempenho por parte do estudante, que, mesmo não possuindo conhecimento pré-adquirido, consegue aprender com o apoio dos recursos disponíveis.

ISLEs geralmente oferecem um simulador ou algum processo de simulação, helps avançados, sugestões, explicaçбes e facilidades de orientação. Tais ambientes podem oferecer ao estudante uma rota orientada (guided tour) que os conduza através da simulação, de acordo com suas necessidades instrucionais específicas.

Apesar dos recentes desenvolvimentos, e apesar do fato de numerosos simuladores serem utilizados em instrução com sucesso de aprendizado, o número de pesquisas sobre como fomecer suporte a estudantes em aprendizado exploratório ainda é muito pequeno. Alguns sistemas que oferecem esse tipo de ambiente são:

- QUEST: detecção de problemas em circuitos eletrônicos (White \& Frederiksen, 1990);

- MACH-III: manutenção e detecção de problemas em um dispositivo de radar complexo (Kurland \& Tenney, 1988);

- IMTS: detecção de problemas em dispositivos complexos (Towne et al., 1990);

- Smithtown: microeconomia (Shute \& Glaser, 1990);

- Enxuto: auxílio no aprendizado de conceitos sobre manufatura industrial (Baranauskas et al., 1997);

- SATELIT-1: suporte ao aprendizado da linguagem de programação utilizada para efetuar a operação e a manutenção de Estações de Telefonia Digital (Direne, 1997).

\subsubsection{Arquitetura Geral de um ISLE}

A arquitetura geral de um ISLE é muito parecida com a arquitetura geral de um STI, devido ao fato de que ambos possuem módulos e forma de comunicação entre esses 
módulos semelhantes, compare as Figuras 2 e 7. Isto ocorre por estarem relacionados ao mesmo objetivo: Ensino e Treinamento e também por terem comportamento semelhante, ou seja, armazenam informações sobre cada usuário, tomam decisões a partir de características do usuário e da informação a ser apresentada, possuem conhecimento sobre determinado domínio e também devem possuir interface bem projetada, devido a grande importância da comunicação simples e fácil entre sistema e usuário.

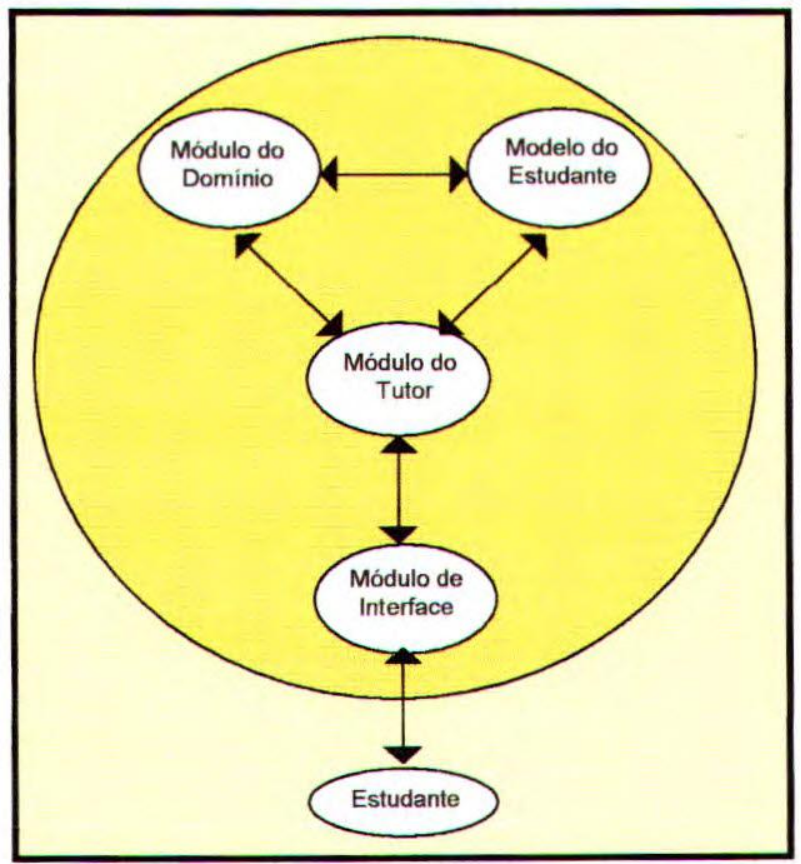

Figura 7 - Arquitetura Geral de um ISLE (Nwana, 1990).

\section{A) Módulo do Domínio}

A base de uma simulação é algum tipo de modelo de domínio. Estes modelos podem diferenciar em uma variedade de dimensões, por exemplo: número de parâmetros, número e tipo de relações (estáticas, dinâmicas, qualitativas e quantitativas), etc.

Uma representação de um domínio está fortemente relacionada ao modelo e suas características; esta representação de domínio pode ser usada não apenas para formar a simulação, mas também para funcionar como base de conhecimento para o suporte oferecido por um ISLE. 


\section{B) Modelo do Estudante}

O Modelo do Estudante provê meios de avaliar o conhecimento do estudante (Kuyper et al., 1993). Estudantes mostram um número de características cognitivas e não-cognitivas que têm significado na interação com o simulador (com tutor embutido). Estas características vão de conhecimento de domínio, utilização de processos de aprendizado até, por exemplo, autocontrole. Um ISLE necessita adaptar instruçōes às diferenças individuais dos estudantes, às suas concepções erradas, e às alterações do conhecimento do estudante que se desenvolvem durante o processo de aprendizado. Conhecimento sobre esses aspectos do estudante compõe a base para a modelagem de estudantes em um ambiente de aprendizado inteligente.

\section{3) Módulo do Tutor}

Este módulo provê meios/estratégias de transferência de conhecimento para o usuário (Kuyper et al., 1993). Um Sistema Tutor Inteligente precisa de conhecimento sobre estratégias de ensino e facilidades de ajuda. No campo de simulação, diversas abordagens de ensino podem ser consideradas, como por exemplo: Diálogo Socrático (no qual o tutor ajuda o estudante, através de diálogo direto, perguntas e respostas, a examinar seu raciocínio e ainda a descobrir e ajustar falhas em seu raciocínio (Kass, 1994)); Implementação de Modelo Progressivo, no qual o tutor avança o ensino mediante desempenho do estudante em relação à compreensão e desenvolvimento de tarefas definidas pelo tutor; e Raciocínio Baseado em Casos (RBC), cuja essência, conforme já mostrado, se resume na utilização de experiências passadas como casos análogos para solucionar problemas atuais, já que aprender através de experiências passadas é uma característica marcante no aprendizado humano.

\section{4) Módulo da Interface com o Estudante}

A interface com o estudante possui dupla função. Ela precisa ser projetada de maneira que a saída do sistema seja de fácil entendimento para o usuário, e que o usuário possa facilmente transformar suas próprias ações em informações de entrada para o sistema (Norman \& Draper, 
1986). Saídas apresentadas em tela, para simulações, podem abranger desde tabelas até gráficos completos. Alguns dos aspectos de interface usuário-computador possuem um caráter mais geral que precisam ser especificados para o trabalho com simulação (por exemplo, manipulação direta de dados), considerando também os outros que são mais específicos para simulação (por exemplo, fidelidade da interface, no sentido de estreitar o máximo possível a relação entre o modelo e a realidade). É necessário que sejam observados atenciosamente os aspectos de interface que são específicos para aprendizado com simulação, para que se saiba como e quando apresentar ajuda, e que tipo de ajuda requerida precisa ser apresentada e que ao mesmo tempo se adapte às necessidades particulares.

Os ISLEs também podem se beneficiar de recursos hipermídia, conseguindo assim melhorar consideravelmente a interação com o usuário, já que hipermídia é uma tecnologia de interesse geral que tem sido alvo de um grande número de pesquisas e desenvolvimento de trabalhos, tanto em âmbito comercial como científico. As características gerais de uso de Sistemas Hipermídia no Ensino são discutidas a seguir.

\subsection{Sistemas Hipermídia para o Ensino}

Os sistemas hipermídia surgiram como uma nova classe para o gerenciamento de informações, pois permitem criar, anotar, unir e compartilhar informações a partir de uma variedade de meios como: textos, gráficos, sons, vídeos e animações, proporcionando o acesso às informações de uma forma não seqüencial e utilizando métodos inteiramente novos, ao contrário dos sistemas de informação tradicionais que são seqüenciais por natureza (Chiaben, 1996).

A flexibilidade de acesso à informação, juntamente com a capacidade de exploração (navegação) de hiperdocumentos, faz com que estes sistemas se tornem bastante atrativos para a utilização como programas de recuperação de informação. Sob esta perspectiva, quanto mais controle o usuário tiver sobre o material a ser examinado, maior chance de sucesso haverá na interação com o sistema.

Seguindo essa linha de raciocínio, a tecnologia hipermídia chama também a atenção dos desenvolvedores de programas para instrução, pois o estudante, ao contrário de seguir caminhos que 
o autor pré-estabelece, pode seguir seus próprios caminhos, de acordo com seus interesses, o que faz com que ele passe a ser ativo e não passivo, ocupando um papel participante em seu próprio aprendizado (Schank, 1994). O estudante torna-se, assim, o foco de atenção dos sistemas de instrução, ao invés do material didático, como tem sido comum em aplicações desta natureza.

Idéias como estas produzem argumentos favoráveis a uma liberdade total da exploração do material instrucional. O controle que o estudante tem possibilita-o a realizar escolhas que afetam $o$ andamento do aprendizado, o que resulta num cenário em que a atividade de estudar se torna mais pessoal e interessante, com o estudante sentindo-se mais competente. Ao ter controle sobre o aprendizado, o estudante pode aprender melhor como estudar.

No entanto, atualmente, vários experimentos têm mostrado justamente o contrário. Tem-se notado que existem situações em que o usuário apresenta melhor rendimento quando é guiado ou orientado de alguma forma. Large (Large, 1996), por exemplo, diz que realizar ligaçōes entre as informações do documento pode ser necessário para o aprendizado, porém, não é suficiente, pois não se leva em conta fatores como a idade, a habilidade e a experiência anterior do usuário tanto quanto seu domínio sobre tais sistemas.

Argumenta-se, também, que existe pouca evidência empírica que mostre uma contribuição educacional relevante na "liberdade total". Com base em indagações como estas, surgem idéias de complementação para os Sistemas Hipermídia que visam realizar um acompanhamento do aprendizado e, para tanto, um maior controle do programa sobre o aprendizado torna-se necessário (Nunes \& Fortes, 1997).

A questão do controle sobre a navegação do usuário assume um papel vital em aplicações hipermídia no ensino. A liberdade maior na exploração do material didático tem algumas vantagens bastante evidentes (Chiaben, 1996): a) o estudante, ao navegar livremente pelo hiperdocumento, cria virtualmente uma porção relevante para seus objetivos, que representa uma visão própria do conteúdo; b) o aspecto exploratório induz a participação ativa do leitor fazendo-o refletir sobre o material; c) as ligações estabelecidas pelo autor fazem transparecer uma estrutura lógica muitas vezes não visível em outro tipo de representação; d) tendo controle sobre o processo de aprendizagem, o estudante é capaz de aprender como aprender; e) ao tomar decisões instrucionais, o estudante descobre as melhores táticas para diferentes situações.

A introdução da tecnologia de hipermídia provocou, de imediato, uma reação bastante otimista nos educadores e desenvolvedores de softwares educativos. Teorias cognitivas foram 
prontamente associadas ao modelo e a literatura foi enriquecida com discussões a respeito de seu uso para fins educativos. No entanto, desde cedo, alguns pesquisadores já alertavam para a pouca evidência empírica da relevância educacional dessa tecnologia (Locatis et al., 1989; Morariu, 1988) apud (Nunes et al., 1993) ${ }^{3}$. Problemas associados à orientação durante a navegação podem resultar no redirecionamento de recursos mentais supostamente dedicados ao aprendizado. Porém, o fator que mantém acesa a chama dessa controvérsia é, sem dúvida, o controle que o estudante é capaz de ter sobre o material didático em Sistemas Hipermídia.

A ausência total de controle do sistema passou a ter um papel oneroso sobre o estudante: é ele agora quem deve tomar as decisões apropriadas para o aprendizado ocorrer de fato, ou seja, deve ter um papel ativo nas estratégias de aprendizagem. Ele agora deve decidir que caminhos seguir, quando voltar ou pular adiante, quando seguir uma determinada trilha e quando evitar as distraçōes com possíveis caminhos irrelevantes. A demanda cognitiva sobre o estudante agora é certamente maior. A grande questão subjacente passa a ser: "Estudantes beneficiam-se da versatilidade e flexibilidade de Sistemas Hipermídia, ou tais sistemas na verdade impedem o aprendizado?".

Ainda que a resposta possa favorecer a primeira alternativa, o fato é que tão logo os primeiros testes reais com usuáriós tornaram-se possíveis, os resultados obtidos começaram a indicar o valor relativo da liberdade total oferecida ao usuário desses aplicativos. Essa discussão de fato antecede o surgimento de Sistemas Hipermídia. Steinberg apud (Nunes et al., 1993) ${ }^{4}$ relata experiências no período de 1977 a 1988 que não evidenciam fortes argumentos a favor do controle do estudante. Segundo a autora, o melhor que se poderia esperar, em média, com o controle pelo estudante é que ele produzisse resultados iguais aos produzidos com o controle pelo programa. Para estudantes com desempenho inferior no tópico em questão, a posse do controle sobre o material teve efeito negativo quando comparado com o controle do sistema. A maioria deles aprendia menos quando de posse de controle do que quando uma sequiência pré-determinada era seguida. Dois problemas encontrados merecem destaque: os estudantes não eram eficientes na determinação de estratégias de revisão e freqüentemente não ponderavam o tempo disponível com a tarefa determinada. Várias outras experiências mais recentes evidenciam nenhuma, pouca ou relativa

\footnotetext{
${ }^{3}$ (Locatis et al., 1989) - Locatis, M.R.; Letoumeau, G.: Banvard, R. Hypermedia and Instruction. Educational echnology Research and Development, 37(4), p. 65-77, 1992.

(Morariu. 1988) - Morariu, J. Hypermedia in Instruction and Training: the Power and de Promise, Educational Technology, $\mathrm{n}^{\circ} .28, \mathrm{p.}$ 17-20, 1988. 4 (Steinberg, 1989) - Steinberg. E.R. Cognition and Leamer Control: A Literature Review 1977-1988. Joumal of Computer-Based Instruction, 16(4), p. 117-121. 1989.
} 
importância do controle do estudante (Large, 1996). De um modo geral, os resultados apontam para o uso desvantajoso do controle do estudante no caso em que este seja um iniciante nos tópicos que vai estudar e possua pouco conhecimento anterior no tópico em questão. No entanto, a grande maioria dos sistemas de ensino visa atender exatamente tais usuários. A conclusão a que se chega é que a questão crucial não é a escolha de um ou outro tipo de controle, mas sim a de como estabelecer um equilíbrio de controle entre o estudante e o sistema.

Destacam-se dois recursos dos Sistemas Hipermídia claramente úteis para aplicações de ensino:

- Possibilidade de guardar a trilha percorrida pelo usuário. Trata-se apenas de uma sequêencia de nós percorridos, mas já é um bom começo para uma modelagem da interação.

- Garantia de liberdade de exploração quando for desejável. Em aplicações convencionais, fica difícil oferecer material para exploração em paralelo às atividades sob controle do sistema.

Finalmente, vale destacar a flexibilidade do uso de hipermídia como parte de uma arquitetura que conjuga outros paradigmas de sistemas de ensino. Por exemplo, nada impede que tenhamos um ambiente ISLE (Intelligent Simulation Learning Environment) acrescido de módulos hipermídia.

Como exemplos de sistemas que possuem tais características, vamos comentar, a seguir, alguns dos trabalhos desenvolvidos no Institute for the Learning Science, Northwestern University, USA, envolvendo o projeto e a implementação de ambientes que integram simulação, recursos hipermídia, Sistema Baseado em Conhecimento e Sistemas Tutores Inteligentes. Tais projetos contaram com apoio de algumas empresas americanas prestadoras de serviço, como: IBM, Andersen Consulting e Ameritech, no que diz respeito ao desenvolvimento dos softwares.

\subsubsection{O Projeto CASPER}

CASPER (Kass, 1994) se enquadra em uma classe de Ambientes Inteligentes de Aprendizado por Prática (Learning-By-Doing Environment - ILDE) e foi criado para proporcionar aprendizado no desenvolvimento de hipóteses sobre sistemas complexos. 
As atividades de treinamento desse projeto combinam textos, gráficos, vídeos e sons, produzindo sistemas que permitem a um estudante aprender praticando em um computador, sob os "olhos vigilantes" de um tutor.

O tutor pode intervir quando necessário para providenciar orientação, muitas vezes em forma de palavras ditas por técnicos mostrados em vídeo. O tutor responde a perguntas do estudante, explicando porque coisas podem estar acontecendo e, além disso, oferece suas próprias experiências para ilustrar os princípios implícitos que o estudante deve aprender.

CASPER é utilizado como um simulador de um sistema de atendimento a clientes, através do qual os funcionários da British Water Company tentam solucionar, em tempo real, problemas que lhes são enviados pelos clientes sob forma de reclamações via telefone.

$\mathrm{O}$ ambiente de treinamento se resume em uma conversa simulada entre cliente (virtual) e funcionário, onde o cliente descreve a situação-problema, e a partir de casos já ocorrido, informações e instruções que o CASPER oferece, o funcionário tenta encontrar uma solução para o problema, antes de entrar em contato com clientes reais e dados em tempo real.

A partir de casos já ocorridos, CASPER ensina funcionários novatos a atender às reclamações feitas pelos clientes, antes mesmo de entrar em contato com estes clientes.

\subsubsection{VICTOR}

VICTOR (Schank, 1990) é um Interactive Learning System (ILS), direcionado às necessidades reais da Illinois Bell, uma subsidiária da Ameritech, que oferece um curso de manejo de telefone aos seus clientes que adquirem sistemas telefônicos e requerem ajuda para treinamento de seus funcionários (operadores, recepcionistas e secretárias) no aperfeiçoamento de prática ao atender o telefone.

VICTOR não utiliza processamento em linguagem natural. Para o sistema entender o que o usuário está dizendo, a resposta ao sistema precisa ser construída, a partir de uma lista préestabelecida de possíveis subfrases que podem ser boas ou más dentro do contexto corrente. Após cada diálogo, o estudante tem a oportunidade de ouvir a gravação da conversação simulada e avaliar a si mesmo. 


\subsubsection{DUSTIN}

DUSTIN (Schank, 1990) é um sistema de treinamento de inglês, desenvolvido para funcionários da Andersen Consulting que não falam inglês e que vão para os Estados Unidos a treinamento.

DUSTIN é baseado em simulação e os estudantes têm acesso a um ambiente com recursos multimídia através do qual interagem com pessoas com as quais eles possivelmente interagiriam no cotidiano. São oferecidos aos estudantes objetivos tais como o de se hospedarem em um hotel e, ao chegarem lá se depararem com um recepcionista que fala apenas inglês. $O$ recepcionista recebe $o$ estudante como na vida real, exceto que aqui o estudante está assistindo a um vídeo. $O$ estudante então digita sua resposta em inglês, e tenta verificá-la. Se a resposta do estudante for bem sucedida, o sistema direciona o estudante a outras tarefas, como por exemplo, encontrar-se com um companheiro de quarto. Se o estudante falha, DUSTIN tenta remediar a ação apresentando exemplos ou dividindo a tarefa em partes menores. A idéia básica é oferecer ao estudante uma chance de praticar inglês enquanto executa tarefas que enfrentaria no cotidiano. $O$ sistema também oferece um Sistema Tutor Inteligente responsável pelo direcionamento do usuário em suas lições e também pelo auxílio a esses usuário durante as lições.

\subsubsection{CREANIMATE}

CREANIMATE (Schank, 1990) é um tutor de biologia, que tem crianças como público alvo e que possui como vantagem a afinidade natural entre crianças e animais. O que se teve em mente para o desenvolvimento deste sistema foi algo animado como o especial de TV National Geographic, onde são apresentadas, entre outras, características físicas e biológicas dos animais que vivem em florestas. O objetivo principal de CREANIMATE é que o estudante possa explorar o domínio baseado em seu próprio interesse, tendo sua jornada organizada com base em princípios gerais, ajudando-o a pensar sobre biologia durante o caminho de descobertas. A solução foi oferecer ao estudante alguma tarefa interessante a ser executada e na tentativa de resolver tal tarefa, o estudante conta com a ajuda de vídeos. 
O programa CREANIMATE oferece ao estudante uma oportunidade de utilizar sua imaginação. $\mathrm{O}$ sistema pede ao estudante que proponha um novo animal. $\mathrm{O}$ animal que o estudante propõe forma a base para um diálogo entre o estudante e o tutor sobre características físicas desse animal e como estas características o ajudam a sobreviver nas florestas. Durante todo o tempo, o estudante estará assistindo a vídeos do animal em questão, para ilustrar os princípios gerais da discussão. A atual interface de usuário do programa consiste de uma sucessão de janelas de diálogo em que o sistema apresenta os textos de saída e sinais de "pronto" para a resposta do estudante. O usuário responde através da seleção de uma lista de possíveis opções, preenchendo, espaços em branco de sentenças parciais.

Após estudo e análise de características relevantes dos sistemas e recursos computacionais que são utilizados com bons resultados em sistemas voltados para o ensino, chegou-se a uma proposta de ambiente denominado SIATE, que conta com recursos semelhantes aos apresentados nos exemplos descritos nessa seção, ou seja, STIs, RBC, SBC, Recursos Hipermídia e Treinamento através de exercícios práticos, com o intuito de abranger, em um único ambiente, as características mais relevantes e marcantes de cada um desses sistemas e recursos, provendo um ambiente com fins educacionais. 


\section{Sistema Inteligente de Apoio ao Treinamento e Ensino (SIATE)}

Após ter observado as características de alguns Sistemas e Recursos de Apoio ao Ensino, pôde-se analisar algumas das vantagens e desvantagens de utilização desses recursos e chegar-se à proposta de desenvolvimento de um protótipo do ambiente denominado SIATE (Sistema Inteligente de Apoio ao Treinamento e Ensino), que integra formas de Prática e Treinamento, Hipermídia, Sistema Tutor (ST) e Sistema Hóbrido de Conhecimento (SHC).

Como o objetivo principal desta proposta é que o ambiente SIATE promova acesso a conhecimento e sendo a WWW uma das maiores fontes de informação de forma interativa, parece coerente que o SIATE seja uma aplicação WWW. Portanto, a filosofia seguida para a implementação foi definida como sendo a mesma dos hiperdocumentos, com exceção das partes do sistema que exigem uma postura diferente de implementação, como por exemplo, as inferências feitas pelo SHC. O objetivo é que o SIATE venha a ser uma fonte de informação e de instrução local e/ou remota.

Aplicaçōes do SIATE têm como característica marcante a liberdade do estudante em estudar sobre um domínio específico (por exemplo: Arquitetura de Computadores, Aquisição de Conhecimento, Recursão, etc.) podendo recorrer, quando necessário, ao auxílio de um ST e de um SHC com conhecimento sobre esse domínio. Para a validação desta proposta de ambiente foi desenvolvido um protótipo de uma aplicação do SIATE cujo domínio selecionado foi Aquisição de Conhecimento para Sistemas Inteligentes. Com isso, todos os exemplos apresentados neste capítulo e no capítulo 4 são diretamente relacionados a essa aplicação.

Fazem parte desse trabalho duas alunas do programa de mestrado do ICMC-USP (Instituto de Ciências Matemáticas e de Computação - Universidade de São Paulo), que enfatizam partes distintas do projeto. Uma parte corresponde ao projeto de um SHC que oferece suporte ao SIATE no que diz respeito ao conhecimento especialista do ambiente, e a outra, que cabe a essa autora, corresponde ao projeto de um Sistema Tutor que oferece apoio pedaǵgico ao SIATE, e ao desenvolvimento dos recursos hipermídia que estão disponíveis no ambiente. Ambas as partes 

assessoram o estudante enquanto ele navega por um hiperdocumento, ou enquanto ele pratica em um ambiente onde é permitido praticar/treinar dentro dos limites do domínio da aplicação.

O ambiente SIATE tem seu domínio modelado segundo as regras do HDM (Hipertext Design Model) (Garzotto et al., 1993), que é uma forma de modelagem utilizada para representar graficamente aplicações hipermídia.

A importância da formalização de hiperdocumentos, através do HDM, ocorre devido à possibilidade de se criar um modelo para determinado tipo de aplicação hipermídia, que pode ser utilizado para aplicações de diferentes domínios, além de facilitar a visualização da estrutura da aplicação hipermídia como um todo. Para um melhor entendimento do HDM, é importante que se conheça algumas informações sobre o que é e qual a funcionalidade dessa forma de modelagem. Sendo assim, no Apêndice 1 o HDM é apresentando de uma maneira rápida para que se possa obter uma visăo geral sobre como modelar utilizando-o.

A Figura 8 apresenta a modelagem do SIATE, na qual é apresentado um esquema que mostra as entidades que correspondem aos módulos do ambiente (Material Didático, Roteiros, Prática/Treinamento e $\mathrm{Help}$ ) e as entidades que correspondem às páginas por onde o estudante passa antes de ter acesso a esses módulos (Apresentação, Login e Menu de Opçöes). Os elos que ligam estas entidades representam o tipo de navegação disponível no ambiente.

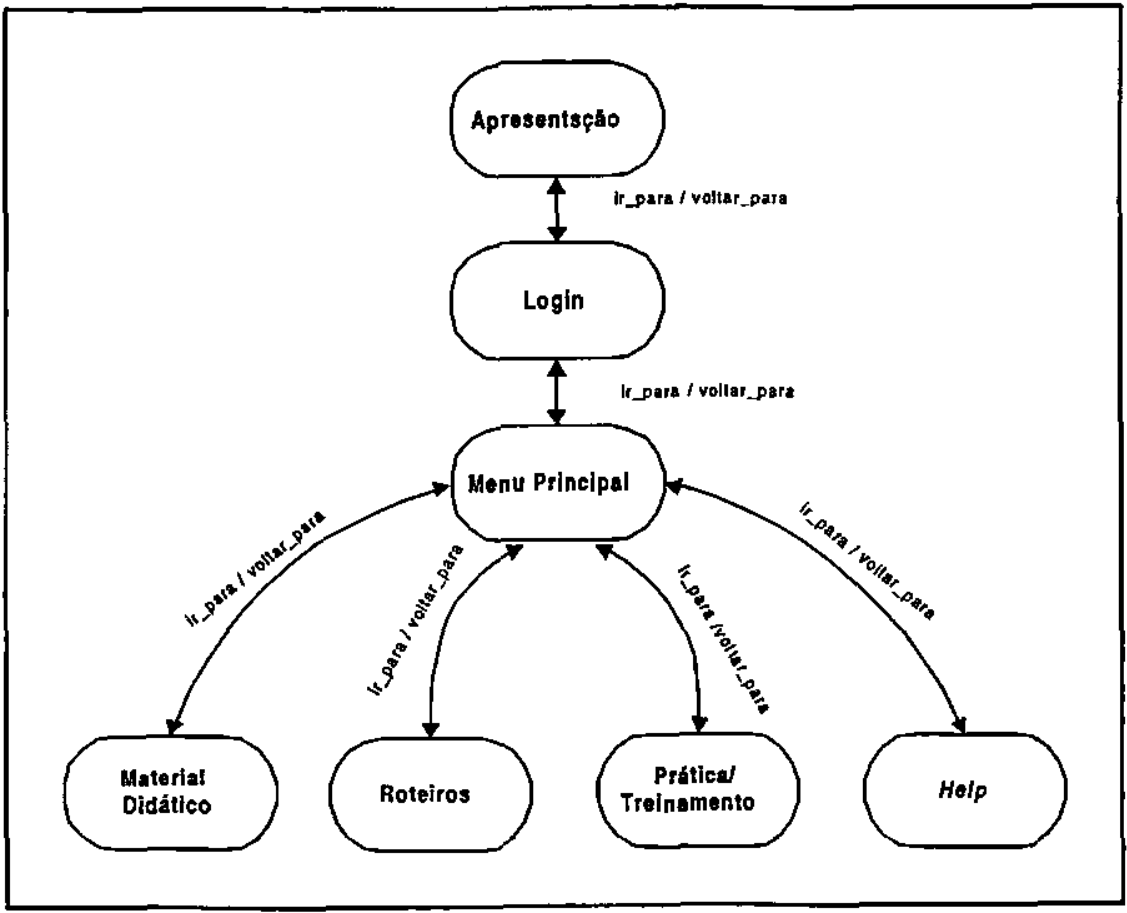

Figura 8-Modelagem HDM do Ambiente SIATE. 


\subsection{Estrutura Geral do Ambiente}

O ambiente que integra Sistema Tutor, SHC, Sistemas Hipermídia e formas de Prática e Treinamento é definido de acordo com os seguintes objetivos:

- fornecer ao estudante a oportunidade de questionar sobre o que ele observa à medida que acessa informações ou efetua (pratica) determinada tarefa;

- estender a gama de conhecimento a ser explorado, de modo que o estudante possa tirar dúvidas conceituais sobre o domínio;

- ilustrar de forma esclarecedora, com casos análogos, as situações que podem ocorrer durante o estudo prático. Tais casos são aqueles considerados representativos por especialistas do domínio. Os parâmetros que indexam os ćasos e que servem de base para a função de similaridade a ser usada devem também ser definidos com tais especialistas;

- armazenar informações a respeito de cada estudante em particular, para que se possa fazer inferências a respeito do progresso ou não do estudante, enquanto ele estuda sobre o domínio da aplicação.

O tipo de interação disponível torna possível ao estudante a livre navegação em um hiperdocumento, cujas informaçōes dizem respeito a uma domínio qualquer, bem como possibilita a utilização irrestrita do ambiente de prática e treinamento, com intervenções do SHC quando requisitado. Como se trata de um ambiente exploratório e de reflexão, evita-se aqui a interrupção involuntária do estudante. Mesmo quando consultado, o tutor deve priorizar as respostas que estimulem a análise da situação, por exemplo, através do fomecimento de casos análogos ou alguma sugestão de atividades, como se resolver algum tipo de exercício proposto, reler alguma informação importante que esteja disponível no hiperdocumento, percorrer algum roteiro pré-definido ou até mesmo sugerir a geração de um roteiro dinâmico sobre o tópico em questão. Pode-se representar, de forma geral, a arquitetura do ambiente, através de três camadas, conforme ilustra a Figura 9. 
A $1^{\text {a }}$ camada corresponde à tela de login do sistema, onde o estudante identifica. É obrigatório, para que tenha acesso às demais camadas do ambiente, que ele esteja devidamente cadastrado e que os dados fornecidos sejam validados.

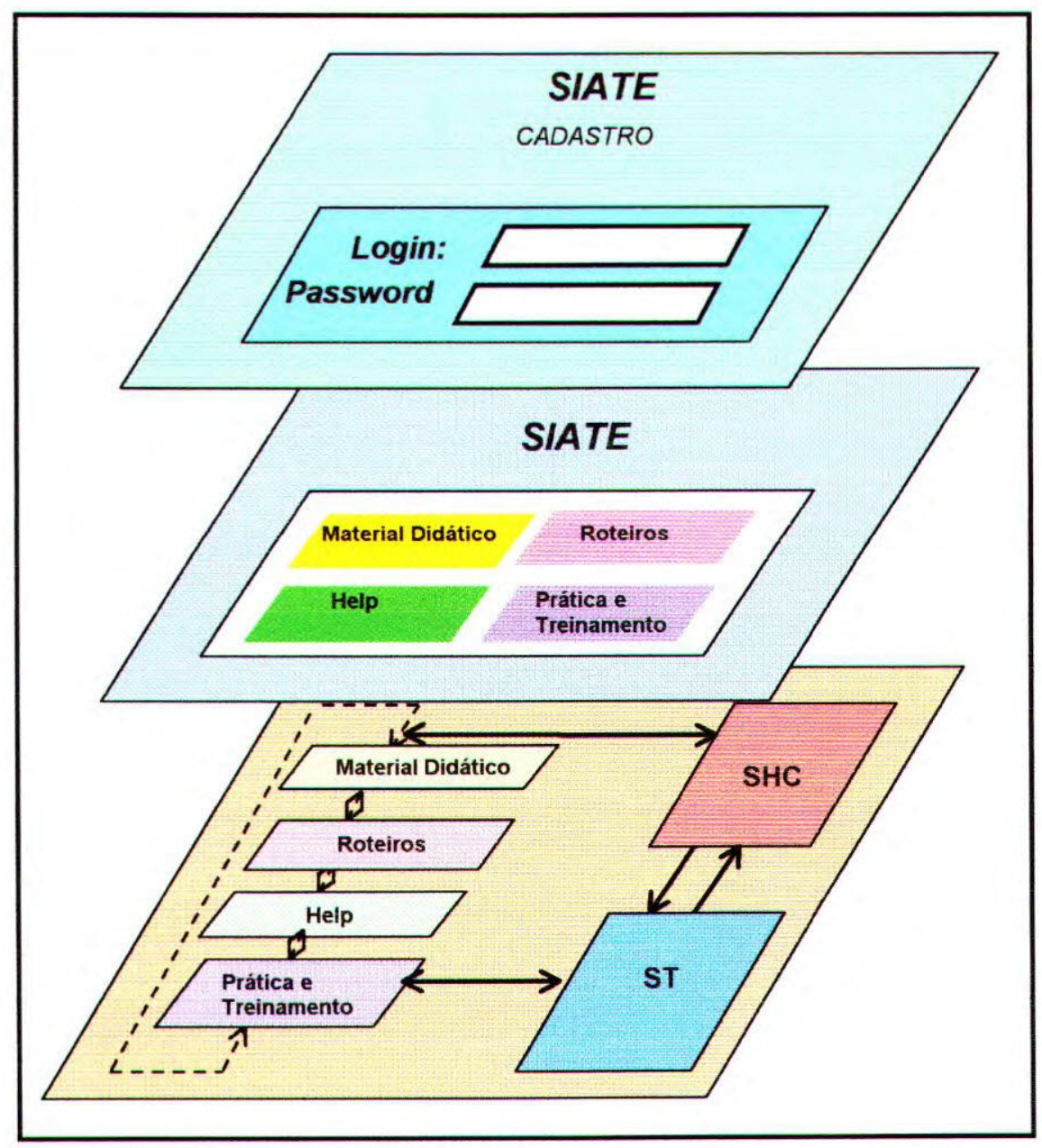

Figura 9 - Arquitetura Geral do Ambiente SLATE.

A $2^{\mathrm{a}}$ camada representa a tela do Menu Principal do SIATE que apresenta os recursos que estão disponíveis no ambiente e disponibiliza o acesso direto a esses recursos. São eles: Módulo Material Didático, Módulo Roteiros, Módulo Prática/Treinamento e Módulo Help, que serão detalhados, individualmente, a seguir na seção 3.2.

A $3^{\text {a }}$ camada é a camada de nível mais baixo, onde está representada a interação entre os módulos (Módulo Material Didático, Módulo Roteiros, Módulo Prática/Treinamento e Módulo Help) e que recebem apoio de mais dois componentes (sistema de apoio pedagógico e instrucional, 
representado pelo ST e sistema de apoio especialista, representado pelo SHC) do ambiente. Além da interação entre módulos e componentes, existe também a interação dos módulos entre si e dos componentes entre si.

A seguir é detalhada a arquitetura do ambiente, com uma descrição de cada módulo e cada componente, suas funções específicas e a interação entre eles. O componente ST é apresentado com mais detalhes no Capítulo 4, por se tratar do enfoque principal dessa dissertação.

\subsection{Elementos que compõem o Ambiente SIATE}

A Figura 10 ilustra os processos de comunicação (ocorre quando, através de um dos módulos, é permitido que o estudante acione outros) e de transferência de dados (ocorre quando um dos componentes está requisitando alguma informação a outro, ou então quando está devolvendo respostas a alguma tarefa que foi requisitada) entre os módulos e os componentes do ambiente.

\subsubsection{Interface}

É a partir desse módulo que se torna possível a interação entre o estudante e o SIATE. Foram utilizadas para a construção, tanto da interface do SIATE como um todo, quanto dos seus módulos e componentes individualmente, as regras e técnicas de desenvolvimento de interface propostas por (Preece et al., 1994) em estudos feitos sobre Interação Usuário-Computador. Tais regras abrangem características como: disposição, tamanho e representatividade de ícones, representatividade das cores, número e equilíbrio de objetos dispostos na mesma tela e demais pontos importantes para a obtenção de aplicações com recursos visuais em um nível aceitável de interatividade.

Inicialmente, todo estudante que tentar acessar o SIATE (seja ele um usuário já cadastrado ou um usuário que está acessando o ambiente pela primeira vez) passa, obrigatoriamente, por uma página de identificação de estudante (Figura 11), contendo um pequeno formulário, onde são requisitados login e password, porque essas informações são pré-requisitos para o livre acesso a qualquer parte do SIATE. 


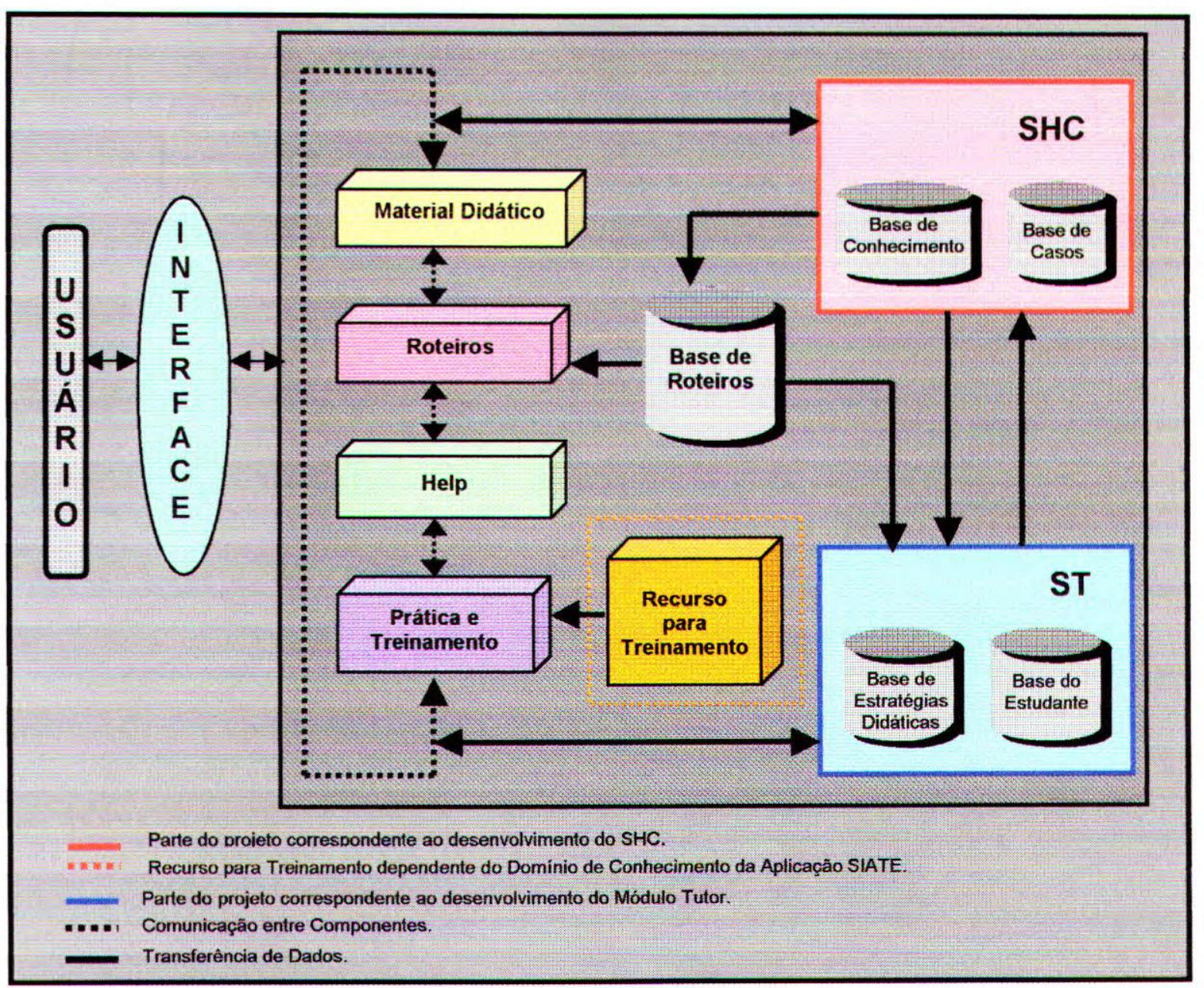

Figura 10 - Elementos que compõem o Ambiente SLATE.

Caso o estudante esteja acessando o sistema pela primeira vez, após serem fornecidas e validadas essas informações, o estudante é então conduzido a uma segunda página, contendo outro formulário, onde são requisitadas mais algumas informações, só que agora, com o intuito de obter dados pessoais do estudante, como por exemplo: nome completo, sexo, idade, nível de conhecimento sobre o domínio, profissão e objetivo de acesso. As informações obtidas através de ambos os formulários são relevantes para a composição da Base do Estudante, que é parte integrante do Sistema Tutor, onde são armazenadas informações relacionadas ao estudante. 


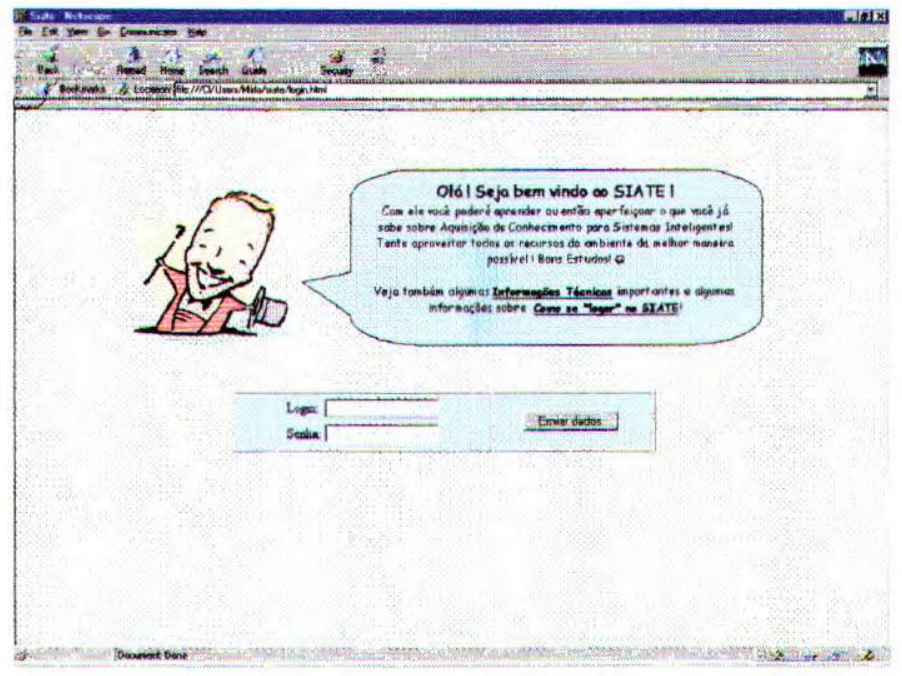

Figura 11 - Tela de Identificação do SLATE

Depois que o estudante tiver sua identificação validada, ele é conduzido a uma nova página. Essa nova página corresponde ao Menu Principal do SIATE (Figura 12), e é composta por uma tabela onde as opções do menu são dispostas sob a forma de cinco botões acompanhados por ícones, cuidadosamente selecionados com o objetivo de facilitar, ao estudante, a associação da figura com o recurso oferecido. As cinco opções do menu correspondem aos 4 módulos do sistema (Material Didático, Roteiros, Prática/Treinamento e Help) e à opção Sair.

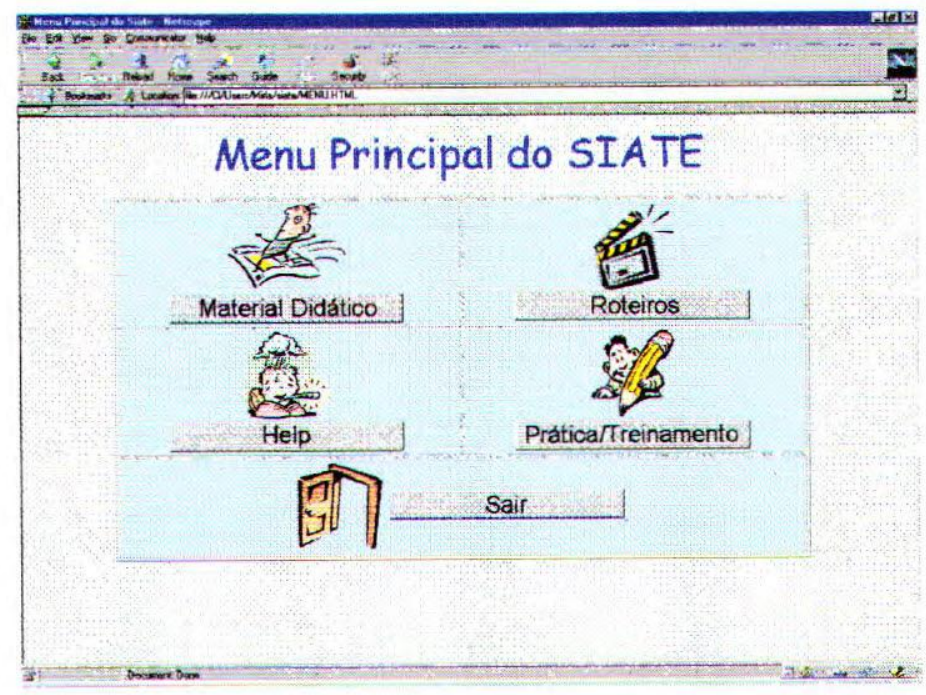

Figura 12 - Tela do Menu Principal do SLATE. 


\subsubsection{Módulo Material Didático}

O Módulo Material Didático (Figura 13) consiste de um hiperdocumento para WWW que contém informações não apenas sobre o domínio da aplicação, como também sobre o ambiente de ensino SIATE. A partir desse módulo, podem ser acessados os demais módulos através de um botão (disponivel em todas as páginas do hiperdocumento) que conduz o estudante ao Menu Principal do SIATE visto na Figura 12.

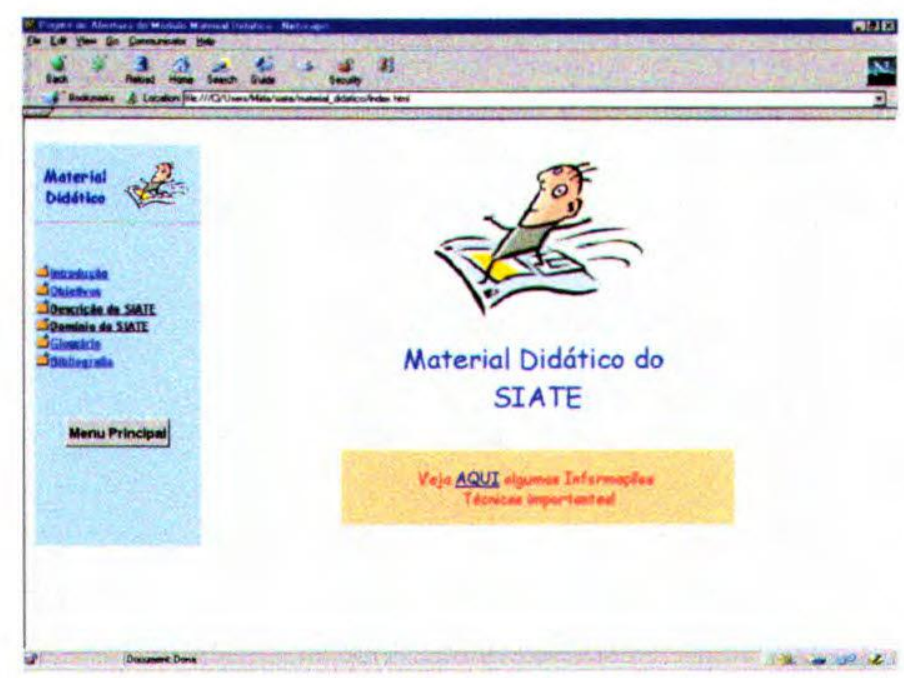

Figura 13 - Página Principal do Módulo Material Didático.

Este módulo tem como objetivo principal inserir o estudante no contexto da arquitetura proposta e também do domínio do sistema. São oferecidas aqui dicas sobre a melhor forma de navegação e utilização do Material Didático, descrições sobre as características do domínio da aplicação e sobre as características do ambiente SIATE, fornecendo ao estudante uma visão geral sobre o ambiente com o qual está interagindo.

Pode-, também, obter informações sobre o público alvo do sistema, ou seja, a quem estão sendo destinadas tais informações e recursos, sobre a bibliografia utilizada e referenciada, o glossário dos termos técnicos utilizados e, finalmente, algumas informações técnicas relacionadas à utilização do Material Didático, que poderão ser importantes para o estudante.

Para a implementação desse módulo, foi utilizada a Linguagem HTML (Hipertext Markup Language) (Venetianer, 1996), juntamente com Applets Java, JavaScript e CGIs (Commom 
Gateway Interface), e MiniSQL, que foi utilizado para armazenar as informações sobre as páginas que compõem este módulo. São armazenadas sobre cada página características como:

- identificação da página, mais especificamente o nome do arquivo, ex.: AC.html;

- classe a que pertence (veja sobre classes a seguir em Modelagem do Hiperdocumento), mais especificamente a qual das classes do domínio do módulo Material Didático ela faz parte, ex.: Informações sobre o Domínio;

- tópico específico que é descrito na página, ex.: Aquisição de Conhecimento Geral.

Estas informações são armazenadas para que o componente Sistema Tutor, conhecendo a página na qual o estudante teve dúvidas, possa fazer sugestões (exercícios, exemplos, etc.) baseado nas características das páginas pelas quais o estudante passou ou não.

O Material Didático tem o seu domínio (domínio da aplicação hipermídia, ou seja, o ensino, o que não quer dizer o mesmo que domínio do conhecimento da aplicação, que é o assunto que o ambiente pretende "ensinar") formalizado utilizando-se o HDM, que foi citado no início deste capítulo e, com mais detalhes no Apêndice 1.

\section{Modelagem do Hiperdocumento}

Baseado no modelo HDM, que tem como uma característica relevante a simplicidade de representação do domínio das aplicações hipermídia, foi então criado um esquema (modelo) para o Módulo Material Didático de um ambiente de ensino qualquer, e a partir desse esquema, definiu-se uma instância (aplicação do modelo) correspondente ao Módulo Material Didático do SIATE.

Chegou-se a um esquema simples, onde podem ser vistas as classes de informações que são oferecidas pelo Material Didático de um ambiente de ensino. Essas classes são representadas como tipos de entidades ou entidades, e as páginas que fazem parte dessas classes como componentes dos tipos de entidades.

Foi decidido para esta modelagem, que o conceito de unidade corresponde exatamente aos componentes dos tipos de entidades, já que não foi utilizado o recurso de separar conteúdos de informação, quanto ao seu tipo de mídia, segundo os conceitos do HDM. Isto quer dizer que as 

mídias foram agrupadas em um mesmo nó adequadamente, porque, em se tratando de um ambiente de ensino, onde a interface com o estudante é um dos pontos mais importantes do ambiente, acredita-se que é extremamente relevante, por exemplo, que enquanto o estudante lê algum texto, ele visualize uma figura que seria a representação gráfica desse texto, facilitando assim a assimilação da informação.

A modelagem é composta inicialmente pela entidade Informações Tutoriais, que corresponde ao domínio do Módulo Material Didático como um todo. A partir dessa entidade obteve-se mais 5 entidades, que correspondem às subdivisões desse domínio (Figura 14).

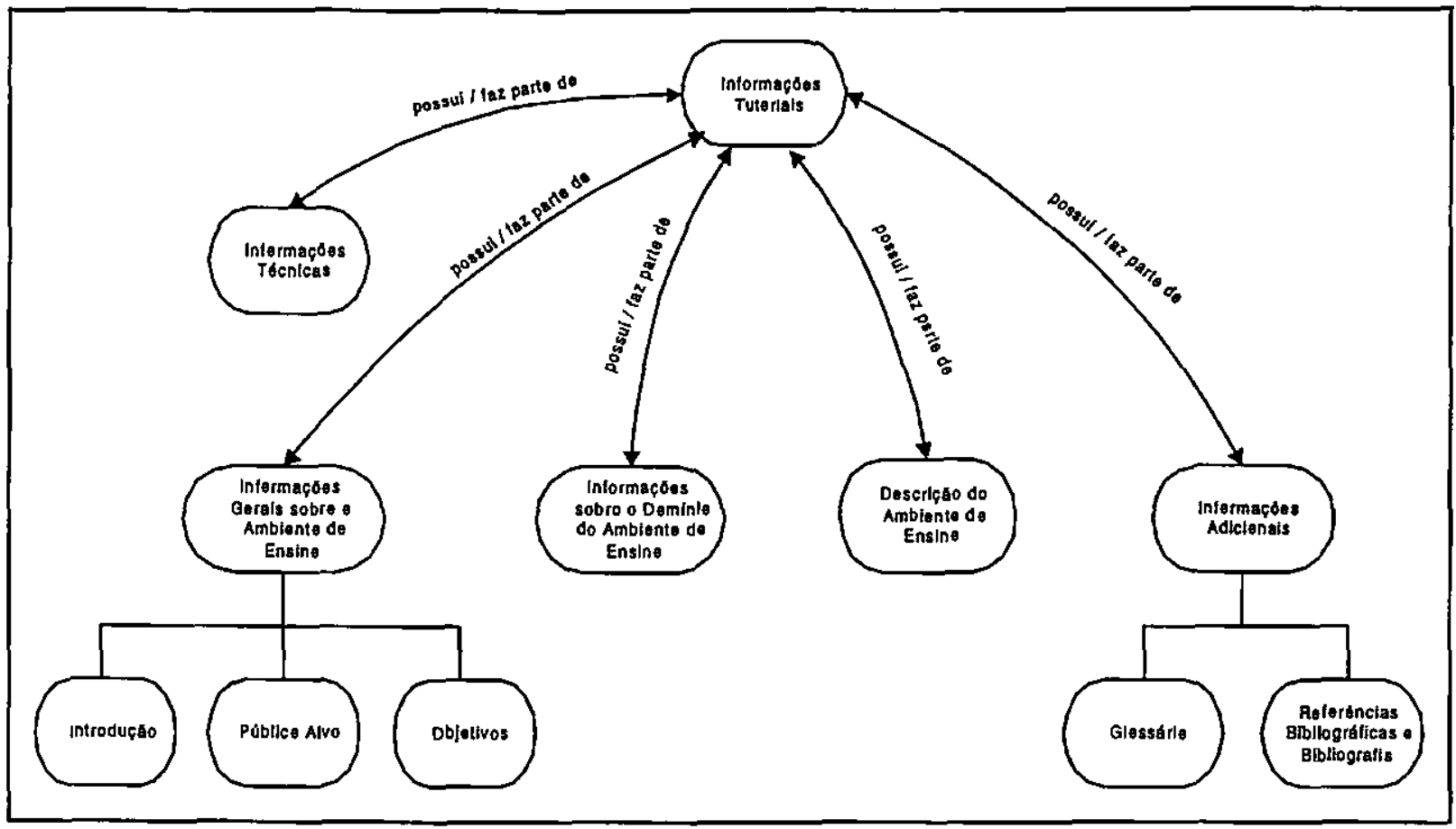

Figura 14-Modelagem HDM do domínio do Módulo Material Didático para um ambiente de ensino qualquer.

A primeira das entidades que fazem parte da entidade Informaçōes Tutoriais, denominada Informacões Técnicas, diz respeito às informações relevantes para um melhor funcionamento do Material Didático, como por exemplo, resolução de vídeo e configuração de browser apropriadas. As demais entidades representam um grupo de informaçōes que é apresentado sob a forma de frame e que funciona como um "índice" que está disponível constantemente em todas as páginas do Módulo Material Didático. São elas: 
- Informações Gerais sobre o Ambiente de Ensino: envolve informações generalizadas sobre o ambiente de ensino como um todo.

- Informações sobre o Domínio do Ambiente de Ensino: envolve características específicas sobre o domínio do ambiente.

- Descrição do Ambiente de Ensino: informações sobre o ambiente, como por exemplo, funcionalidades dos seus módulos e componentes.

- Informações Adicionais: constitui informações relevantes que podem enriquecer de alguma forma o aprendizado do estudante, como por exemplo, glossário e referências bibliográficas.

A aplicação de cada entidade e cada componente do esquema da Figura 14 ao Módulo Material Didático do ambiente SIATE, consiste de uma instância desse esquema obtida para o SIATE com um domínio de aplicação qualquer. Neste caso, podemos mapear cada tipo de entidade do esquema para uma entidade da instância SIATE, como por exemplo:

Tabela 1 - Mapeamento de Tipos de Entidades do Esquema para Entidades da Instância SIATE.

\begin{tabular}{|l|l|}
\hline \multicolumn{1}{|c|}{ Tipos de Entidades do Esquema } & \multicolumn{1}{c|}{ Entidades da Instância SIATE } \\
\hline 1) Informaçōes Tutoriais & 1) Informaçōes Tutoriais do SIATE \\
\hline 2) Informaçōes Técnicas & 2) Informaçōes Técnicas do SIATE \\
\hline 3) Informaçōes Gerais sobre o Ambiente de Ensino & 3) Informaçōes Gerais sobre o SIATE \\
\hline 4) Informaçōes sobre o Domínio do Ambiente de Ensino & 4) Informaçōes sobre o Domínio do SIATE \\
\hline 5) Descriçāo do Ambiente de Ensino & 5) Descrição do Ambiente SIATE \\
\hline 6) Informaçōes Gerais & 6) Informaçōes Gerais do SIATE \\
\hline
\end{tabular}

Em relação aos elos de aplicação do esquema, eles podem também ser considerados como tipos de elos de aplicação, que se adaptam sem nenhum problema a qualquer instância do esquema.

No protótipo de aplicação do SIATE, por exemplo, as primeiras páginas dos conjuntos que fazem parte das entidades Informações sobre o Domínio do Ambiente de Ensino (Figura 15) e Descrição do Ambiente de Ensino (Figura 16) podem ser vistas nas figuras a seguir. 


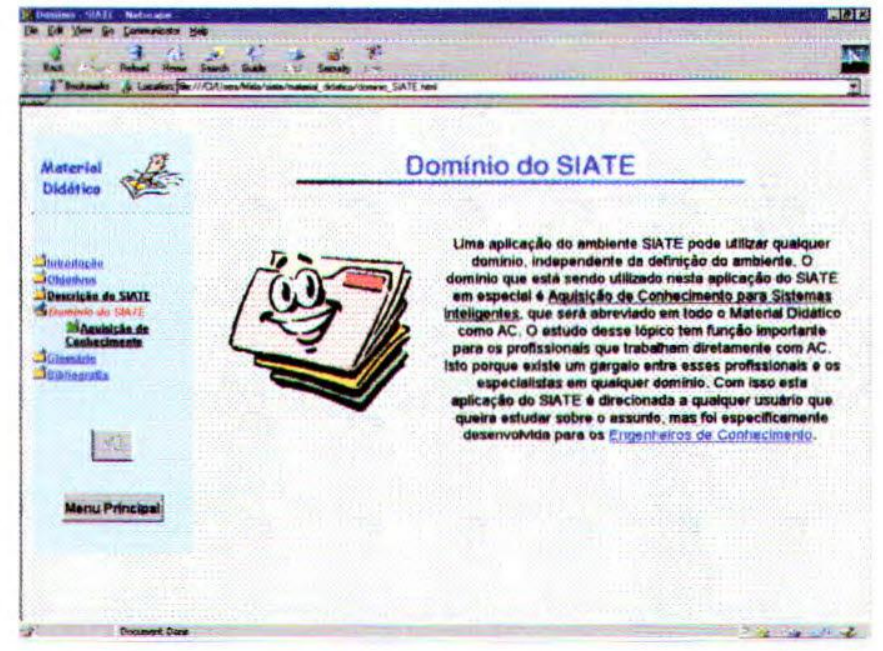

Figura 15 - Página principal sobre o dominio Aquisição de Conhecimento.

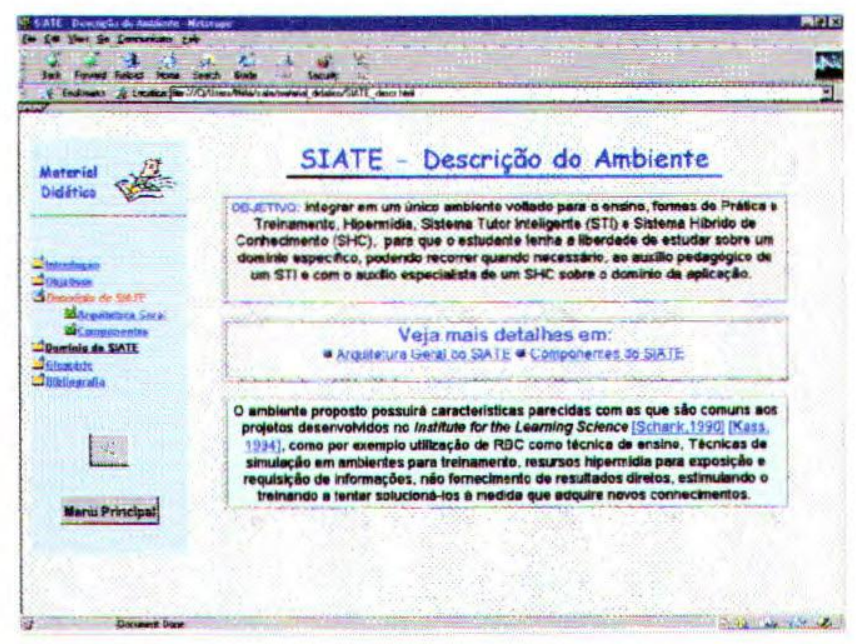

Figura 16-Página principal sobre o Ambiente SLATE.

\subsubsection{Módulo Roteiros}

Trata-se de um módulo onde estão disponiveis os roteiros (guided-tour) para navegação direcionada. Aqui, também, é livre o acesso aos demais módulos do ambiente (Módulo Material 
Didático, Módulo Prática/Treinamento e Módulo Help), através do botão que conduz ao Menu Principal do SIATE.

O Módulo Roteiros pode ser descrito como sendo composto por dois submódulos: a) Geração de Roteiros e b) Seleção de Roteiros, que podem ser vistos na Figura 17 a seguir.

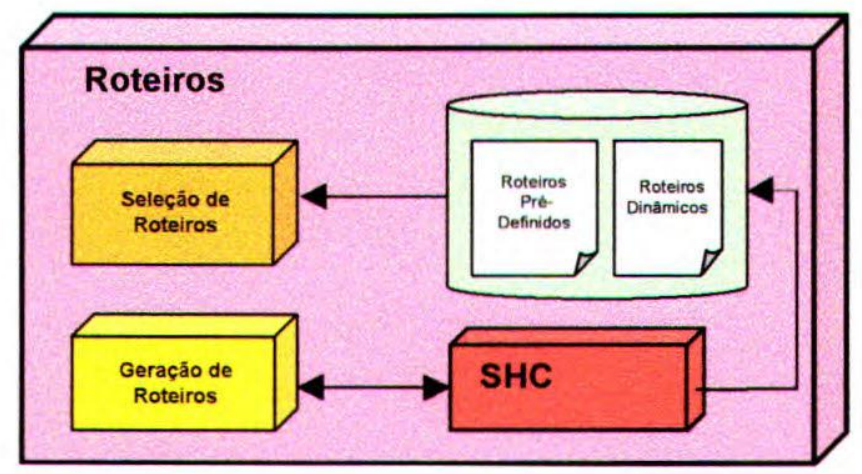

Figura 17 - Submódulos do Módulo Roteiros.

A Geração de Roteiros ocorre por iniciativa própria do estudante ou então por sugestão feita ao estudante pelo ST. O roteiro é gerado a partir de inferências efetuadas pelo SHC que, baseado no tópico escolhido, nas necessidades e situação atual do estudante, no que diz respeito à performance nos estudos (esta performance é avaliada através do conhecimento, do ST, sobre as páginas que foram ou não visitadas pelo estudante), tenta produzir uma seqüência de páginas que melhor adaptem às necessidades desse estudante. A geração de roteiros disponibiliza apenas roteiros sobre o domínio da aplicação do SIATE. Como esse submódulo está ligado ao SHC, sua interface ainda está sendo desenvolvida pelo projeto de mestrado responsável pelas funções do SHC.

A Seleção de Roteiros é efetuada diretamente pelo estudante, que encontrará a esta altura, um menu contendo alguns roteiros definidos com o intuito de guiar o estudante pelo melhor caminho, segundo o autor do Material Didático. Esta opção é mais indicada para estudantes que ainda não estão completamente familiarizados com o ambiente e com o domínio de conhecimento da aplicação SIATE. Por exemplo, podemos observar na Figura 18 o menu de roteiros para o protótipo desenvolvido. 


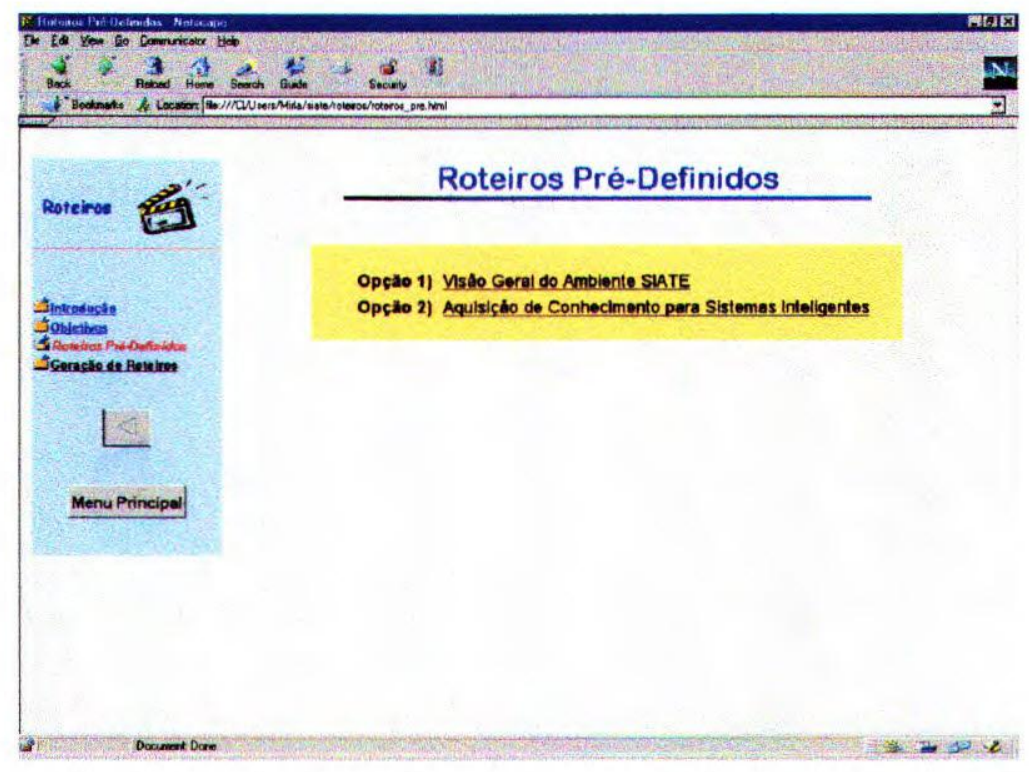

Figura 18 - Menu de Opções do Submódulo Seleção de Roteiros.

Os roteiros, independente do submódulo de que fazem parte (Seleção de Roteiros, quando são pré-definidos, ou Geração de Roteiros, quando gerados), podem ser visualizados graficamente através de um grafo, onde cada nó corresponde a uma página do roteiro em questão.

A visualização desse grafo é acionada através de um botão que está sempre disponível nas páginas do roteiro. O grafo é apresentado em uma nova janela de browser que pode ser aberta e fechada em qualquer ponto da navegação. As páginas são representadas por ícones significativos e descrições associadas ao conteúdo dessas páginas (Figura 19).

A visualização é gerada baseando-se no roteiro que estiver sendo utilizado, com o intuito de oferecer ao estudante a possibilidade de localizar dentro do caminho que está sendo percorrido.

Uma observação importante, que constitui uma característica relevante dos roteiros, é que, caso o estudante desvie do caminho através dos links disponíveis nas páginas, ele pode retomar a navegação do roteiro no mesmo ponto em que a abandonou através do acionamento dos botões Anterior ou Próxima. Ambos, o grafo e os botões de navegação dos roteiros podem ser vistos na Figura 19, que corresponde a uma página do roteiro pré-definido sobre Aquisição de Conhecimento do protótipo desenvolvido. 


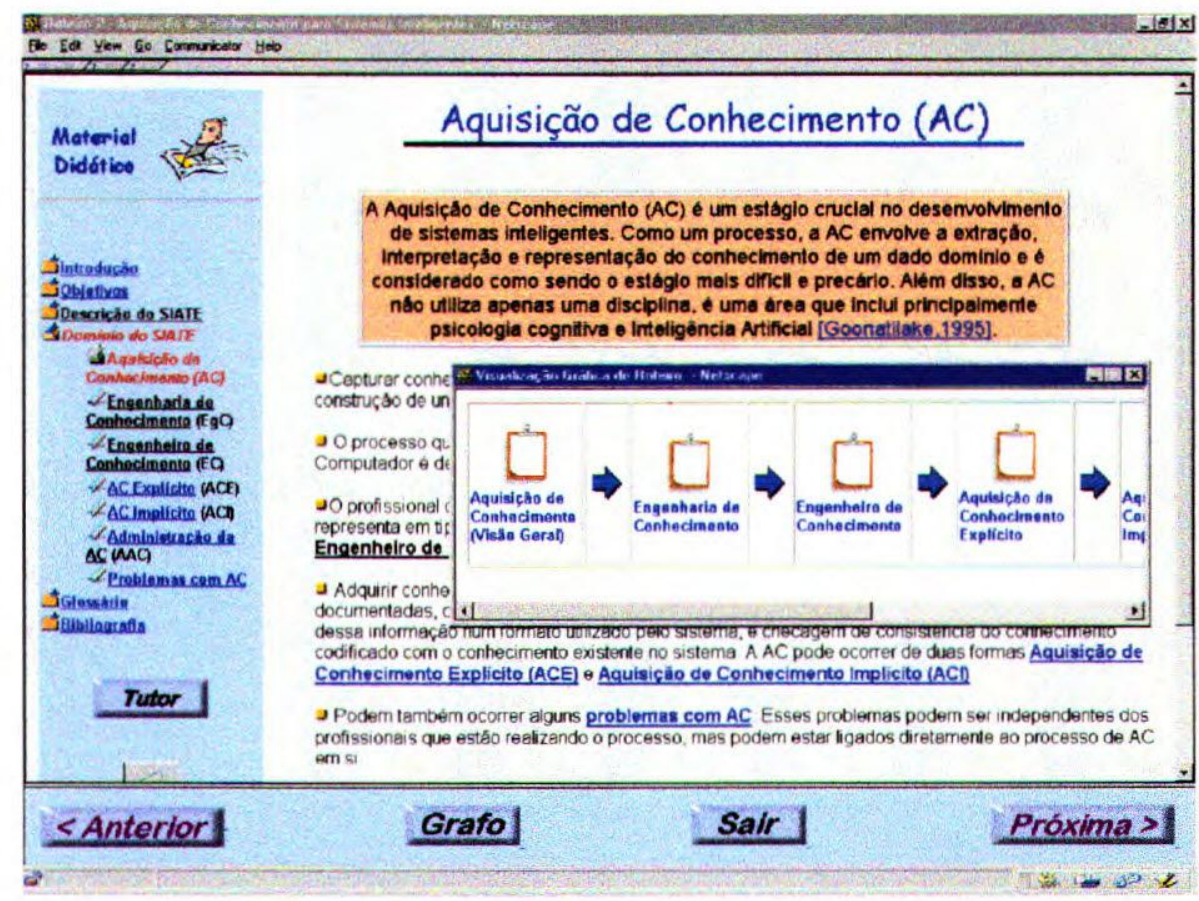

Figura 19 - Grafo e Botões de navegação do Roteiro Aquisição de Conhecimento do protótipo.

Isto possibilita ao estudante a oportunidade de, por exemplo, visualizar uma página que pode não ser a próxima do roteiro ou até mesmo não fazer parte daquele roteiro, mas que despertou o seu interesse naquele momento, e logo depois, voltar a seguir o caminho em que estava.

\subsubsection{Prática /Treinamento}

Nesse módulo, o estudante pode treinar/praticar dentro do domínio da aplicação, com o apoio especialista do $\mathrm{SHC}$.

O Módulo Prática/Treinamento utiliza como instrumento de trabalho algum recurso que possibilite ao estudante praticar, treinar ou até mesmo simular (dependendo das possibilidades do domínio de conhecimento da aplicação) em algum tipo de representação do mundo real. Dado este tipo de liberdade, as tarefas que podem ser realizadas e os recursos de ajuda variam de acordo com o recurso utilizado para a prática/treinamento.

A Interface do Módulo Prática e Treinamento, que abriga o recurso específico de cada aplicação (Figura 20), é dividida em três partes distintas com funções também distintas. A primeira 
delas tem o formato de um menu de opções, cujo conteúdo são botões representando os recursos de apoio oferecidos pelo SHC, que podem ser utilizados pelo estudante, enquanto ele explora o recurso de prática/treinamento na segunda e maior parte da interface. A terceira parte da interface é a menor delas e é destinada à exibição das respostas do SHC.

Os botões disponíveis nesse módulo, mais especificamente na primeira parte da tela principal, se dividem em quatro classes: Dúvidas, Controle, Desempenho e Utilitários.

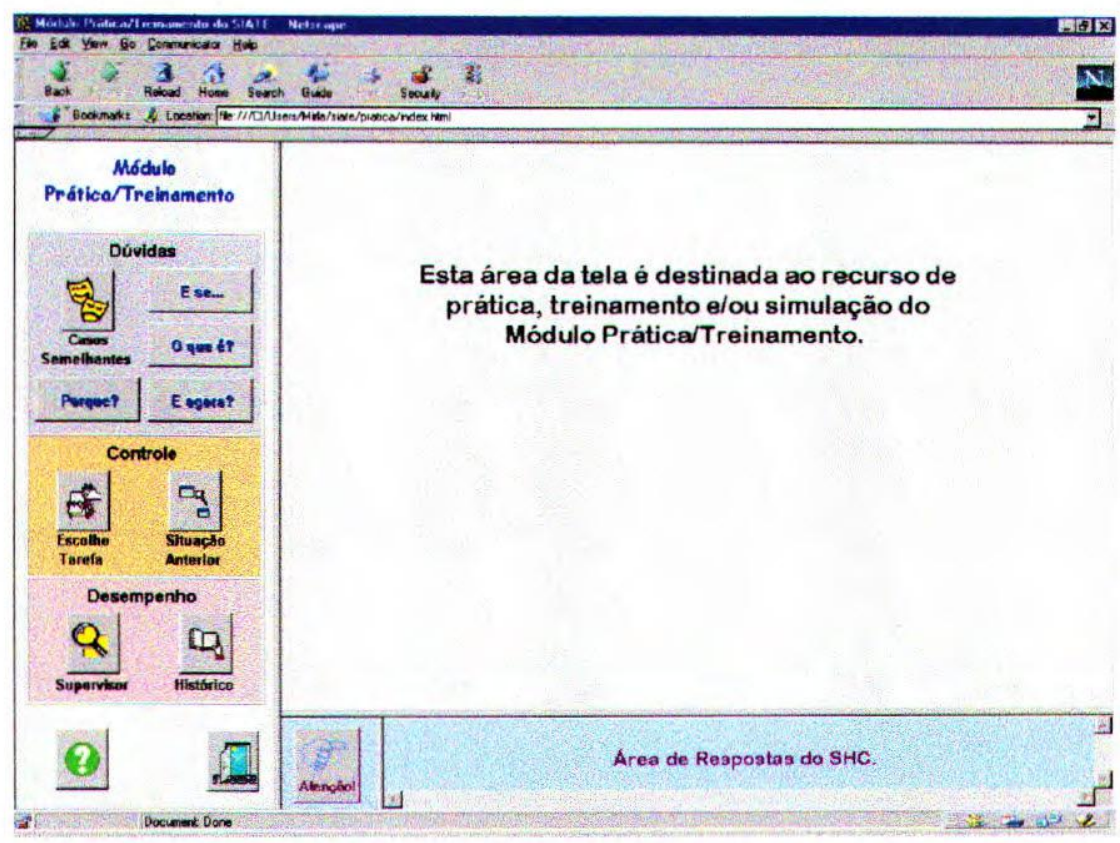

Figura 20 - Tela Principal do Módulo Prática Treinamento do SIATE.

Os botões da classe Dúvidas são os botões cuja função, como o próprio nome diz, é tentar esclarecer as dúvidas sobre o domínio da aplicação que o estudante possa vir a ter durante o tempo que estiver praticando/treinando. Todas as respostas, neste caso, são produzidas pelo SHC. São eles: 1)Casos Semelhantes: através do qual o estudante pode requerer um caso semelhante ao caso em que estiver trabalhando em determinado momento, tentando assim visualizar mesmo que com algumas diferenças, como poderia chegar à solução do seu atual problema.

2)E ... : através do qual o estudante pode questionar sobre o que poderia acontecer caso ele alterasse, por exemplo, algum parâmetro do problema atual. 
Capítulo 3 - Sistema Inteligente de Apoio ao Ensino e Treinamento (SIATE)

3) $\underline{\text { que é? }}$ : através do qual o estudante pode tirar dúvidas sobre um ponto específico. A resposta a esse tipo de pergunta pode ser tanto o resultado de uma inferência feita pelo SHC, como também apenas uma consulta a uma base de dados.

4)Porque? : através do qual o estudante pode questionar sobre o porquê de determinado resultado.

5)E agora? : através do qual o estudante pode questionar sobre o que fazer em uma situação em que se encontra sem saber que atitude tomar.

O botões da classe Controle são os botões cuja função é disponibilizar ao estudante a flexibilidade de controlar as tarefas que ele deseja executar. São eles:

1)Escolhe Tarefa: através do qual o estudante pode selecionar a tarefa que deseja executar. Estas tarefas dependem do recurso de treinamento disponível.

2)Situacão Anterior: através do qual o estudante pode retornar ao problema (resolvido) imediatamente anterior ao que está sendo solucionado.

Os botões da classe Desempenho são os botões cuja função é possibilitar tanto ao estudante avaliar seu próprio desempenho (Botão Histórico), quanto ao supervisor, caso houver, avaliar o desempenho do estudante em questão e também de outros estudantes sob a sua supervisão (Botão Supervisor).

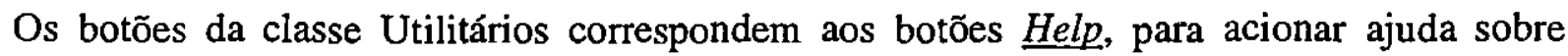

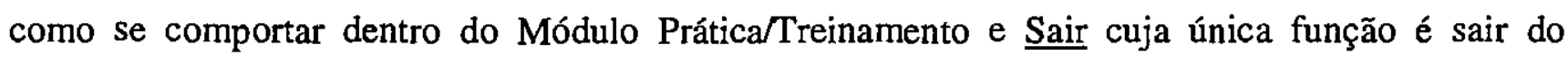
Modulo Prática/Treinamento e voltar ao Menu Principal do SIATE.

Além do uso dos botões, pode ser necessário que o estudante forneça informações adicionais ao SHC durante alguma inferência. Nesse caso, as perguntas são respondidas através da montagem de frases. Estas frases são formadas por subfrases pré-definidas que fazem parte de menus onde o estudante faz a seleção que for necessária para montar a sua resposta.

A subdivisão dessa interface que é destinada ao recurso de treinamento, no protótipo utilizado para validação da proposta do SIATE, está sendo projetada para abrigar a interface da Biblioteca MLC++ (Félix et al., 1998), que é composta por algoritmos de aprendizado de máquina e será mais detalhada na seção 3.2.8.

O objetivo aqui é deixar que o estudante explore o ambiente livremente, requisitando ajuda quando sentir necessidade.

Como esta interface está diretamente ligada aos recursos oferecidos pelo SHC, que ainda está sendo desenvolvido, e cuja atuação pode variar dependendo do domínio da aplicação, ela pode 
sofrer alterações tanto visuais como funcionais, de acordo com as necessidades do SHC, do domínio ou ainda do público alvo da aplicação.

\subsubsection{Módulo Help}

Esse módulo, assim como o módulo Material Didático, corresponde a um hiperdocumento, onde estão disponíveis informações sobre como utilizar cada um dos módulos do SIATE e também como melhor utilizar os recursos oferecidos pelo ST e pelo SHC. As informações estão dispostas em ordem alfabética, o que facilita a busca da informação. Cada título de informação corresponde a um link para uma página onde se encontram as informações a respeito daquele título.

\subsubsection{Sistema Tutor (ST)}

- O Sistema Tutor é um componente do SIATE que oferece apoio pedagógico e instrucional às aplicações desse ambiente. É o responsável por orientar o estudante em relação às suas dúvidas e dificuldades quanto ao domínio da aplicação, enquanto ele navega pelo Material Didático.

Mais detalhes, sobre este componente, são dados no Capítulo 4.

\subsubsection{Sistema Híbrido de Conhecimento (SHC)}

O SHC (Sistema Híbrido de Conhecimento) é um componente do SIATE que oferece apoio especialista, sobre o domínio de conhecimento, às aplicações do ambiente dentro do Módulo Prática/Treinamento. Nesse sentido, é o responsável por assessorar o estudante, baseado no conhecimento que for explicitado em sua Base de Conhecimento.

Esse sistema é híbrido por se tratar de uma fusão de técnicas de IA. Estão envolvidas nessa fusão, técnicas de Sistema Baseado em Conhecimento (SBC), técnicas de Raciocínio Baseado em Casos (RBC), e técnicas para representação de conhecimento como, por exemplo, regras, frames, e casos, onde são representadas experiências passadas sobre determinado domínio de conhecimento. 
Para a implementação do SHC, está sendo utilizado o LPA Prolog em ambiente Windows. A máquina de inferência utilizada é bastante simplificada, uma vez que o foco é a integração dos recursos do SIATE e não cada um deles individualmente.

Não serão apresentados detalhes sobre o SHC, por se tratar de um componente desenvolvido em outro projeto de mestrado (Pugliesi, 1997).

\subsubsection{Recurso de Treinamento}

O SIATE pode abrigar sistemas interativos dedicados ao exercício ou simulação no domínio de conhecimento subjacente. Os recursos de interação disponíveis na interface que contém o Recurso de Treinamento são aqueles apresentados na seção 3.2.4 e Figura 20. Ou seja, qualquer que seja o Recurso de Treinamento, o usuário deve poder fazer perguntas como: E ..., O que é?, Porque?, $\mathrm{E}$ agora?, etc., que devem ser respondidas pelo SHC.

Considerando o protótipo implementado como exemplo de uma aplicação do SIATE, o Recurso de Treinamento utilizado é a Biblioteca MLC++ (Machine Learning Library in C++) (Félix et al., 1998) que é composta por algoritmos de Aprendizado de Máquina, que serão utilizados como forma de Aquisição de Conhecimento Implícito (ACD) e permitirá ao estudante visualizar e exercitar este tipo de Aquisição de Conhecimento. À medida que esses algoritmos são executados e os resultados fornecidos observados, o estudante se familiariza com o processo de ACI. Cada algoritmo tem características específicas, como por exemplo, a forma de leitura e de armazenamento de informações na base de dados e a maneira através da qual os resultados das inferências são apresentados, que pode ser, por exemplo, através de Regras de Produção ou Árvores de Decisão.

Nesse capítulo, foi apresentada a proposta do ambiente SIATE, com a descrição dos seus módulos (Módulo Material Didático, Módulo Roteiros, Módulo Prática/Treinamento e Módulo Help) e uma rápida descrição sobre seus componentes (ST e SHC). Com isso, passaremos agora à descrição mais detalhada do componente Sistema Tutor do SIATE, com suas funcionalidades e seus recursos. 
Este capítulo tem como objetivo apresentar o Sistema Tutor (ST) do Ambiente SIATE, suas características de implementação, de estrutura e suas funções tutoriais.

Para a implementação do ST, foram escolhidas as linguagens HTML e JAVA e seus recursos, que provêm aplicações bastante flexíveis, no sentido de que elas possuem facilidades para tratamento de recursos hipermídia, já que a proposta é que uma aplicação do ambiente SIATE possa ser executada em um browser, ou melhor, que ela seja uma aplicação para o ambiente WWW.

\subsection{Funções Tutoriais}

As funções do ST do SIATE estão disponíveis dentro do Material Didático e também nas avaliações que podem ocorrer ao final do percurso de um roteiro, dentro do Módulo Roteiros. As funções tutoriais, disponíveis no Módulo Material Didático, são destinadas a "supervisionar" a . performance do estudante, enquanto ele estiver navegando pelas páginas do Material Didático. É a partir dessas funções que a Base do Estudante é alimentada. A Tabela 2 mostra quais as funções disponíveis e os objetivos a serem alcançados com as informações obtidas por elas.

Tabela 2 - Funçôes Tutoriais do Módulo Material Didático e seus Objetivos.

\begin{tabular}{|l|l|}
\hline \multicolumn{1}{|c|}{ Funções } & \multicolumn{1}{c|}{ Objetivos } \\
\hline $\begin{array}{l}\text { 1) Identificar através de consulta feita à } \\
\text { Base do Estudante, o nível de } \\
\text { conhecimento de cada estudante. }\end{array}$ & Decidir que nível de informações sugerir ao estudante. \\
\hline $\begin{array}{l}\text { 2) Analisar o caminho (em páginas) } \\
\text { percorrido pelo estudante. }\end{array}$ & $\begin{array}{l}\text { Conhecer o número de páginas do Material Didático que foram } \\
\text { percorridas e se a partir dessas páginas pode-se tomar alguma } \\
\text { decisão, como por exemplo, aplicar um teste para avaliar o } \\
\text { conhecimento do estudante e que tipo de questōes devem fazer } \\
\text { parte desse teste. }\end{array}$ \\
\hline $\begin{array}{l}\text { 3) Avaliar, através de testes, o } \\
\text { desempenho do estudante após percorrer } \\
\text { páginas dentro do Módulo Material } \\
\text { Didático e também após percorrer algum } \\
\text { roteiro. }\end{array}$ & $\begin{array}{l}\text { Armazenar, para uma futura análise de desempenho, como o o } \\
\text { estudante se saiu estudando sobre o domínio de conhecimento de } \\
\text { uma aplicação SIATE. }\end{array}$ \\
\hline
\end{tabular}


As funções tutoriais disponíveis dentro do Módulo Roteiros permitem que o estudante seja avaliado por seu supervisor, se houver um, ou então que o estudante faça, por exemplo, uma análise do seu próprio desempenho nos exercícios.

\subsection{Características de Interação e Funcionamento}

A partir da Figura 21 podemos observar como ocorre a interação entre usuário e ST, bem . como o funcionamento do ST.

Existem duas formas de o estudante interagir com o ST. A primeira delas, através da qual o estudante apenas fornece dados, acontece enquanto ele navega pelas páginas do Material Didático, ou então dentro do Módulo Roteiros, quando ele é avaliado (por exemplo, através de um teste de múltipla escolha) após terminar de percorrer um roteiro. Nesta primeira forma de interação, o usuário não percebe que está sendo supervisionado e que dados relevantes do seu comportamento, como a identificação das páginas por onde ele passou, estão sendo armazenados pelo ST. É através destas informações que o ST toma decisões quando requisitado.

Na segunda forma de interação, o estudante aciona o ST através de um botão disponível apenas e⿳亠㐅⿵ algumas das páginas do Material Didático. Estas páginas são julgadas relevantes pelo projetista dependendo do domínio da aplicação. Quando o ST é acionado, o estudante é conduzido a um menu de opções. Nesse menu estão disponíveis os tipos de auxílio que o ST tem para oferecer, como: Perguntas, Exercícios, Exemplos e Sugestões. Esses tipos podem variar de acordo com o domínio de conhecimento da aplicaçāo e da página do Material Didático. Isto quer dizer que nem sempre estarão disponíveis todos os tipos de auxílio em uma mesma página.

Caso o estudante selecione a opção Perguntas, será apresentado a ele um conjunto de perguntas, as FAQs (Frequently Asked Questions), que são dúvidas que ocorrem com mais freqüência sobre o conteúdo das páginas. Caso a escolha seja por uma das demais opções: Exercícios, Exemplos e Sugestões, são acionados geradores para cada uma dessa opções que, baseando-se nas informações contidas nas Bases do Estudante, de Exercícios, de Exemplos e de Sugestões, selecionam e propõem os exercícios, os exemplos e as sugestões que melhor se enquadram à situação do estudante e ao conteúdo da página atual. 


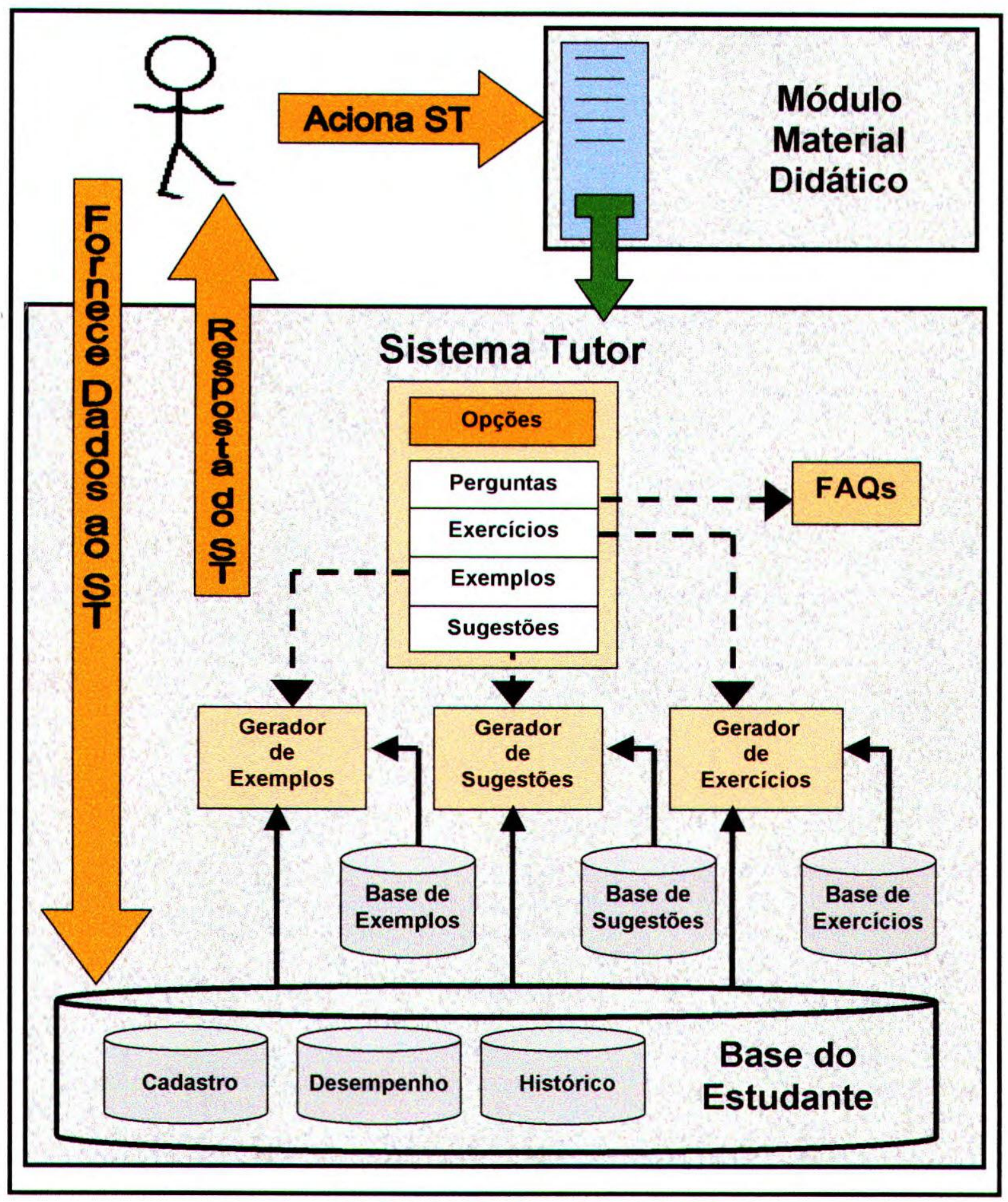

Figura 21 - Estrutura do Sistema Tutor do SIATE. 


\subsection{Características dos Componentes}

Como visto na Figura 21, podemos identificar no ST sete componentes, que se dividem em quatro bases de dados e três geradores:

a) Base do Estudante: armazena informaçōes a respeito das características específicas de cada estudante. É subdividida em três tabelas:

> Tabela Cadastro, onde são armazenadas informações pessoais do estudante como: identificação do estudante, senha, nome, sexo, data de nascimento, profissão e nível de conhecimento sobre o domínio.

$>$ Tabela $\underline{\text { Histórico, }}$ onde são armazenadas informações sobre o estudante enquanto ele estiver navegando/estudando dentro do Módulo Material Didático, como: identificação do estudante, caminho percorrido (ordem das páginas) durante uma seção de login e quais páginas relevantes foram acessadas.

$>$ Tabela Desempenho, onde são armazenados os resultados obtidos pelo estudante na resolução de algum exercício proposto e qual o resultado obtido. Tais informações são: identificação do estudante, identificação do exercício proposto e nota obtida.

Num primeiro protótipo, a Base do Estudante conterá apenas uma visão quantitativa das interaçס̃es com os estudantes, de forma que uma modelagem mais significativa e que contribua mais com o desempenho do tutor deverá ser objeto de trabalhos futuros.

b) Base de Exercícios: armazena informações sobre os exercícios que podem ser propostos ao estudante, como: identificação do exercício, identificação do tópico e classe do domínio da aplicação a que está relacionado, a que nível de estudante é direcionado e também o gabarito desses exercícios. 
c) Base de Exemplos: armazena informações sobre os exemplos que podem ser apresentados e em que páginas especificamente.

d) Base de Sugestões: armazena informações sobre as possíveis sugestões que podem ser apresentadas ao estudante. A apresentação ou não destas sugestões é determinada dependendo do tópico a que a sugestão se refere.

e) Gerador de Exercícios: é o responsável por selecionar os exercícios que melhor se encaixem ao problema, ou seja, à situação em que o estudante se encontra, tomando como base tanto as informações contidas na Base do Estudante (como páginas percorridas e exercícios já resolvidos) como também na Base de Exercícios (que tipo exercício e a que tópico do domínio de conhecimento é direcionado). Podem ser sugeridos questionários ou exercícios de múltipla escolha.

f) Gerador de Exemplos: é o responsável por selecionar, baseando-se nas informações da Base do Estudante e da Base de Exemplos, os exemplos que tenham relação com a página em questão e que ainda não foram vistos pelo estudante. Podem ser sugeridos, por exemplo, casos já resolvidos para exemplificar algo que está sendo motivo de dúvida para o estudante no momento atual.

g) Gerador de Sugestões: é o responsável por apresentar sugestões que sejam representativas para o estudante, baseado no tópico no qual a página se enquadra. Pode ser sugerida a visita a uma página em especial, a navegação por um roteiro pré-definido, a geração de um roteiro sobre o tópico em questão e ainda exercícios práticos que podem ser feitos dentro do Módulo Prática/Treinamento.

\subsection{O Sistema Tutor para uma Aplicação do SIATE}

Considerando a aplicação do SIATE para o domínio Aquisição de Conhecimento (AC) para Sistemas Inteligentes, serão mostrados a seguir alguns exemplos da atuação do ST.

Inicialmente, quando o ST é acionado, o estudante é conduzido a uma página que representa o Menu de Opções do ST (Figura 22). Neste menu, são apresentados os recursos que são oferecidos pelo ST. 


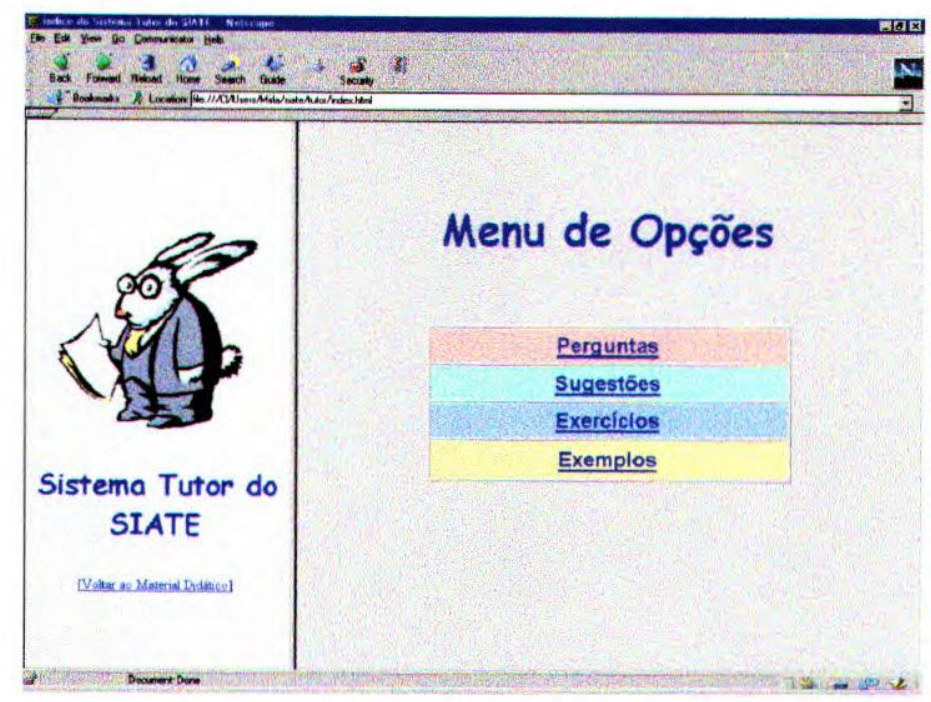

Figura 22 - Menu de Opções do Sistema Tutor do SLATE.

Quando o estudante fizer a sua escolha, um dos geradores fará a análise dos dados e logo a seguir a sugestão relacionada à opção escolhida. Por exemplo, uma situação em que um estudante que não tem quase nenhum conhecimento sobre $\mathrm{AC}$, ou seja, é um iniciante que está navegando pelo Material Didático pela primeira vez, se depara com a página que fala sobre Aquisição de Conhecimento de maneira geral (Figura 23). Ele pode sentir necessidade de auxílio sobre por onde começar a estudar, sendo tal página uma página de introdução ao tópico Aquisição de Conhecimento. Com isso, ele aciona o ST que apresenta o seu Menu de Opções.

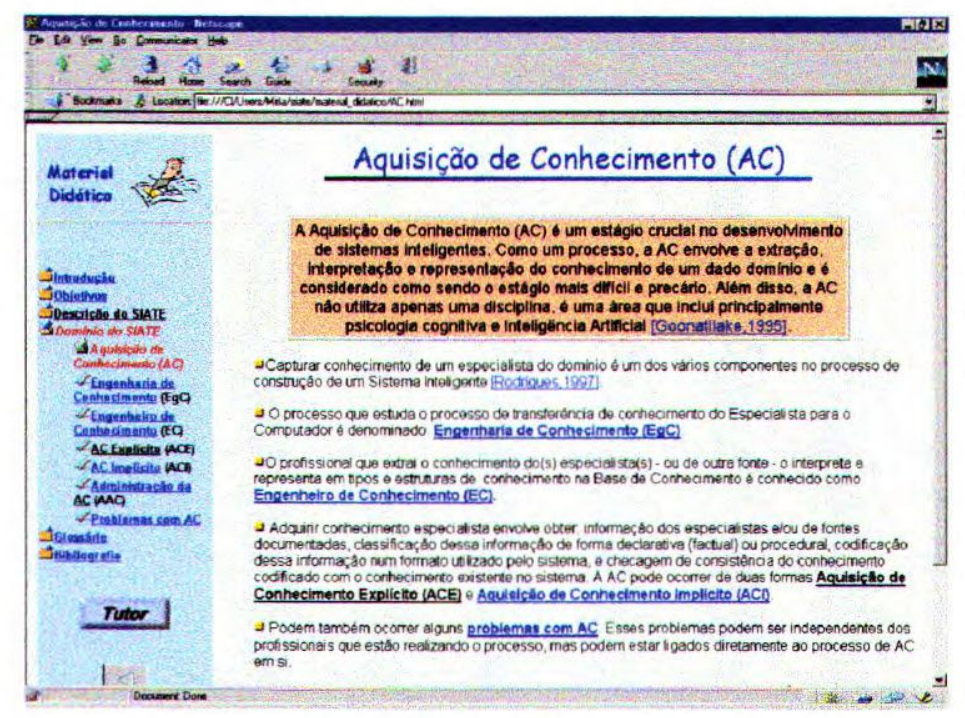

Figura 23 - Página de AC com o botão que aciona o ST. 
O estudante, neste caso, seleciona a opção Sugestões. Feito isso, o gerador de sugestões verifica as informações relacionadas à página atual e também as informações do estudante que são de seu interesse, como por exemplo, as páginas já percorridas por ele, e apresenta as sugestões que são viáveis para aquela situação, como pode ser observado na Figura 24.

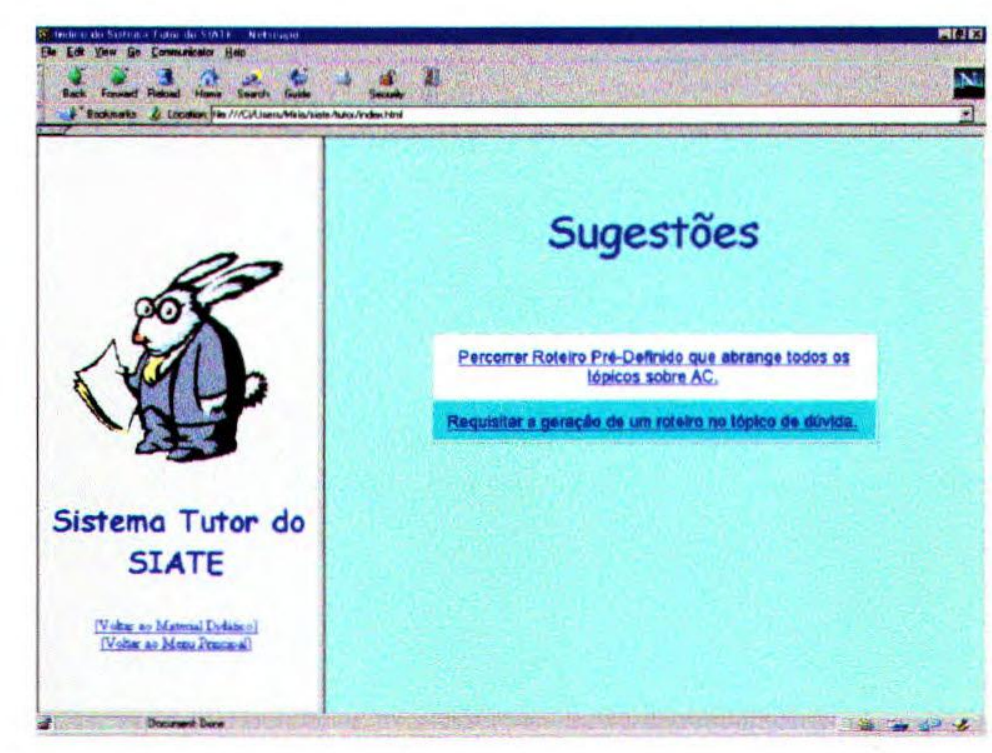

Figura 24 - Página das Sugestões oferecidas pelo ST.

Após conhecer as sugestões oferecidas pelo ST, o estudante seleciona a navegação pelo Roteiro pré-definido que abrange os tópicos sobre AC. Assim, logo que a seleção é concluída, ou seja, um dos links é acionado, o fluxo de execução é desviado para a primeira página do roteiro escolhido.

em outra circunstância, este mesmo estudante selecionasse a opção Perguntas, seriam apresentadas a ele as FAQs que têm relação com a página a partir da qual o ST foi acionado, conforme ilustra a Figura 25.

Outro exemplo seria o de um outro estudante que, com nível de conhecimento intermediário, ao acessar a página sobre Aprendizado de Máquina, que cita a Biblioteca MLC++, sente necessidade de esclarecimento sobre como seria a AC utilizando algum dos algoritmos dessa biblioteca, e pede ajuda ao ST. 


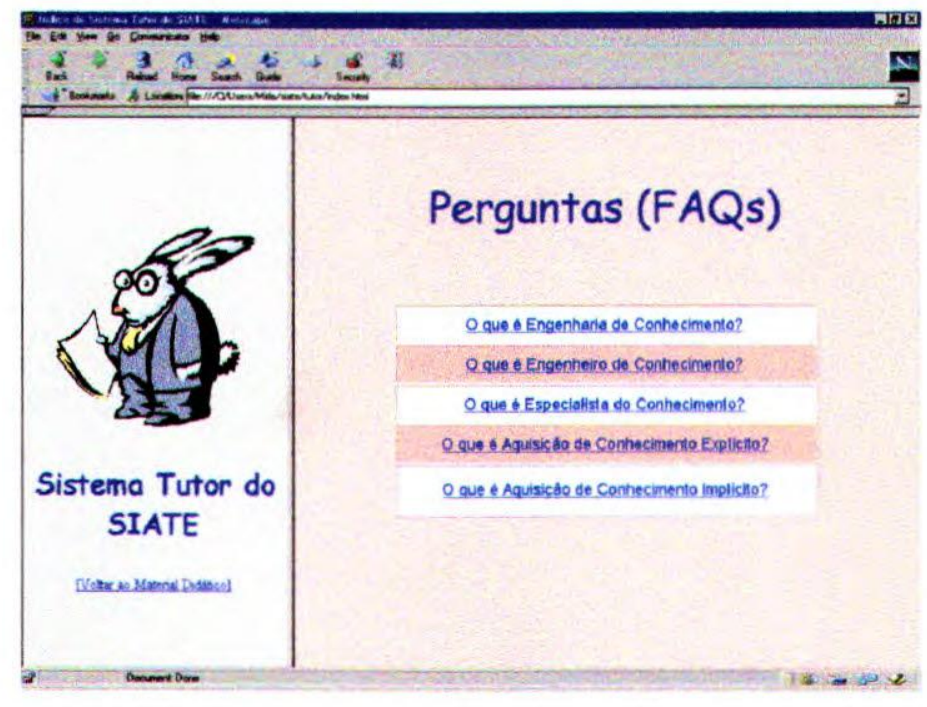

Figura 25 - Página das FAQs para a página AC.

Neste caso, ele seleciona a opção Exemplos e uma das opções apresentadas pelo ST (Figura 26) é um exemplo do algoritmo $\mathrm{CN} 2$, que pode ser visualizado ali mesmo (através de um link que conduz a uma página onde o exemplo é mostrado sob a forma de relatório) ou então executado no Módulo Prática/Treinamento, utilizando- para isto, um conjunto de dados existente. Assim o fluxo de execução pode ser desviado tanto para o Módulo Prática/Treinamento como também para a página de apresentação do exemplo, através de links.

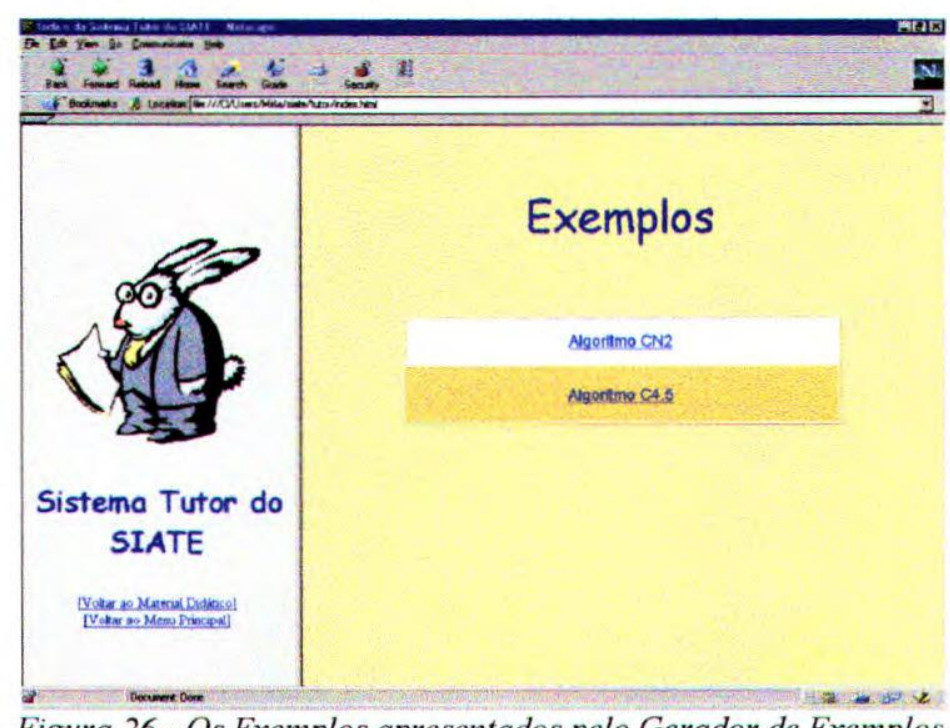

Figura 26 - Os Exemplos apresentados pelo Gerador de Exemplos. 


\subsection{A Característica Modular do Sistema Tutor}

As informações manipuladas pelo ST estão armazenadas sob a forma de conjuntos de dados independentes do domínio de conhecimento da aplicação.

Como exemplo desses conjuntos, podemos citar: as características das páginas, as informações pessoais do estudante, o histórico do estudante e os exercícios que podem ser propostos, tanto para avaliação como também para prática. Veja na Tabela 3 as informações que fazem parte desses conjuntos.

Tabela 3 - Conjuntos de informações manipuladas pelo ST.

\begin{tabular}{|c|c|}
\hline Conjunto de dados & Dados \\
\hline Cadastro: Informações Pessoais do Estudante. & $\begin{array}{l}\text { Identificaçāo do Estudante, } \\
\text { Senha, Nome, Sexo, Profissão, } \\
\text { Data de Nascimento, } \\
\text { Nível de conhecimenlo do Domínio } \\
\end{array}$ \\
\hline $\begin{array}{l}\text { Características das Páginas: Informaçōes sobre as } \\
\text { Páginas Relevantes do Material Didático. }\end{array}$ & $\begin{array}{l}\text { Identificaçäo da Página, } \\
\text { Classe de páginas a que pertence }{ }^{5} \\
\text { T6́pico do Domínio o qual tem como conteúdo, } \\
\text { Número de Acessos ocorridos }\end{array}$ \\
\hline $\begin{array}{l}\text { Histórico do Estudante: Informaçōes sobre a navegação } \\
\text { do estudante. }\end{array}$ & $\begin{array}{l}\text { Identificação da Página que foi acessada, } \\
\text { Ordem em que a página foi acessada, } \\
\text { Número de acesso por estudante específico }\end{array}$ \\
\hline $\begin{array}{l}\text { Desempenho: Informaçōes sobre o desempenho de cada } \\
\text { estudante nos exercícios propostos resolvidos }\end{array}$ & $\begin{array}{l}\text { Identificaçāo do Exercício, } \\
\text { Nota do estudante } \\
\end{array}$ \\
\hline
\end{tabular}

Além desses conjuntos de informações descritos na Tabela 3, todas as informações manipuladas pelo ST e seus componentes (Gerador de Exercícios, por exemplo), que foram vistas na seção 4.3, podem ser alteradas de acordo com cada domínio de aplicação. No protótipo que está sendo apresentado, isto acontece de forma tradicional, ou seja, a base de dados precisa ser acessada e os dados inseridos ou modificados diretamente nas tabelas que compõem essa base de dados.

Uma observação relevante é que esta facilidade de mudança não está disponível apenas ao ST, mas a todo o ambiente SIATE. Com exceção das páginas do Módulo Material Didático que

\footnotetext{
${ }^{5}$ Para a classificação das páginas podem ser utilizadas as classes da modelagem HDM do Material Didático (Seção 3.2.2 e Figura 14) ou entāo podem ser criadas novas classes e subclasses, de acordo com as necessidades do domínio de conhecimento selecionado.
} 
precisam ser criadas uma a uma para cada nova aplicação, as demais informações, como por exemplo, os roteiros pré-definidos (Módulo Roteiros), podem ser alteradas sempre que necessário.

Para facilitar essas alterações seria conveniente a construção de uma ferramenta de entrada de dados, através da qual, o usuário poderia mudar o conteúdo das bases de dados sempre que fosse preciso, baseado em suas necessidades e nas necessidades da aplicação que estivesse sendo desenvolvida. 


\section{Conclusões}

Como o intuito de aperfeiçoar o uso de informática na educação, os CAIs (Computer Assisted Instruction) são alvo de várias pesquisas sobre como melhorar a performance educacional em ambientes voltados para o ensino. Eles têm sofrido várias modificaçōes, adaptaçōes e ganharam recursos que tornaram sua capacidade de "ensinar" mais flexível. Com o aumento da sua flexibilidade obtida a partir destas modificações e adaptações, foram surgindo diferentes tipos de CAIs, com diferentes características educacionais. Por exemplo, um tipo de CAI que suporta comportamento ativo do estudante é o baseado em simulação, onde estudantes exploram ativamente um domínio através da escolha de valores de entrada para um modelo de domínio. Mas, este tipo de CAIs só se torna um ambiente de ensino inteiramente viável, quando o estudante pode contar com o apoio pedagógico de um professor. Esse apoio quando vindo de um ambiente de aprendizado por computador, ou seja, um ambiente com um Sistema Tutor Inteligente embutido, é conhecido como ISLE (Intelligent Simulation Learning Environment). Existe atualmente um grande número desses ambientes, em que é oferecido aos estudantes um ambiente de simulação juntamente com alguns tipos de suporte ao aprendizado.

O ambiente SIATE (Sistema Inteligente de Apoio ao Treinamento e Ensino), proposto aqui, foi projetado nos mesmos moldes dos ISLEs, integrando características de ambientes de Prática/Treinamento (que no caso do SIATE, pode ser um simulador propriamente dito ou então alguma forma de treinamento, dependendo do domínio da aplicação), Hipermídia, Sistema Tutor (ST) e Sistema Híbrido de Conhecimento (SHC) voltado para o ensino e, que tem como característica marcante a liberdade, por parte do estudante, de explorar um domínio qualquer, podendo recorrer quando necessário, ao auxílio de um ST e de um SHC com conhecimento especialista nesse domínio.

O objetivo maior da proposta é complementar um ambiente de ensino baseado na exploração de hiperdocumentos com conhecimento especialista no domínio. No caso do SIATE, tal 
complementação dá através da integração de módulos específicos para o hiperdocumento e o conhecimento do domínio num ambiente único e acessível via WWW. Enquanto que recursos tutoriais oferecem suporte à navegação pelo hiperdocumento, um SHC baseado em regras, frames e casos, oferece suporte a um módulo de prática e treinamento no domínio. Essa dissertação descreve principalmente as características do hiperdocumento e do Sistema Tutor.

Algumas características positivas do ambiente proposto são: o controle (ainda bastante simples) de informações sobre o usuário e conseqüente adequação das ações do tutor; os recursos adicionais de navegação (criação dinâmica e visualização gráfica de roteiros, sugestões do tutor); diferentes formas de intervenção do usuário (através de menus, botões, além das ligações usuais do hiperdocumento).

Foi construído um protótipo de uma aplicação do SIATE cujo domínio é Aquisição de Conhecimento para Sistemas Inteligentes, com o intuito de verificar a viabilidade técnica da integração dos módulos do SIATE. O módulo que abriga o hiperdocumento e as funções tutoriais, bem como as funções de comunicação com o SHC já está implementado. O módulo que abriga o ambiente de prática e treinamento e o SHC está em fase de implementação.

A mudança de domínio no SIATE é possível, porém, esta é uma tarefa que requer um volume razoável de trabalho e de conhecimento sobre a implementação do ambiente. Isto porque, para que o domínio seja alterado, é necessário que o usuário (por exemplo, o professor) construa um novo hiperdocumento e ainda forneça todas as informações (por exemplo, os exercícios, as FAQs e os exemplos relacionados a cada página do hiperdocumento) via MiniSQL. Para minimizar esse trabalho, uma ferramenta de autoria é extremamente desejável. Usando essa ferramenta o usuário forneceria as informações de maneira controlada, evitando possíveis inconsistências e, principalmente, encurtando caminhos.

No entanto, antes de se promover melhorias quanto a autoria, é necessário que o protótipo construído seja adequadamente avaliado com os usuários-alvo, ou seja, os estudantes. Apenas a partir das impressões e, principalmente, do desempenho desses usuários no ambiente proposto, é que a proposta poderá ser validada. Dessa forma, os trabalhos futuros previstos para esse projeto incluem: a) a finalização da implementação do SHC para o protótipo desenvolvido; b) a avaliação do protótipo com os usuários-alvo; e c) possíveis extensões ao ambiente, como por exemplo, um módulo de autoria e modelagem mais detalhada da Base do Estudante. 


\section{Referências Bibliográficas}

(Aamodt \& Plaza, 1994) - Aamodt, A.; Plaza, E. Case-Based Reasonig: Foundational Issues, Methodological Variation and Systems Approaches. AI Communications, v. 7, nº 1, p. 39-59, março. 1994.

(Arantes \& Rodrigues, 1994) - Arantes, A.C.; Rodrigues, S. R. Um Sistema Tutorial para o Ambiente que Auxilia a Construção de Núcleos Específicos de Sistemas Especialistas (ANSEsp). São Carlos/SP, ICMC (Instituto de Ciências Matemáticas e de Computação)-USP (Universidade de São Paulo), 1994. (Relatório Técnico, nº. 19, 48p.)

(Baranauskas et al., 1997) - Baranauskas, M. C. C.; Borges, M. A. F.; Borges, E. L. Learning by Creating Models: A Computer-Based Environmet for Industrial Aplication. In: World Conference on Artificial Intelligence in Education - AIED, v. 39, Kobe, Japan, 1997. Proceedings. p.426-433.

(Batista, 1997) - Batista, G. E. A. P. A. Um Ambiente de Avaliação de Algoritmos de Aprendizado de Máquina Utilizando Exemplos. São Carlos/SP, 1997. Dissertação (Mestrado), ICMC (Instituto de Ciências Matemáticas e de Computação)-USP (Universidade de São Paulo).

(Chiaben, 1996) - Chiaben, H. Um Ambiente Computacional de Aprendizagem Baseado em Redes Semânticas. Curitiba/PR, 1996. Dissertação (Mestrado), CEFET-PR.

(Dekkers \& Donatti, 1981) - Dekkers, J.; Donatti, S. The Integration of Research Studies on the Use of Simulation as na Instructional Strategy. Journal of Educational Research, v. 74, p. 424$427,1981$.

(Direne, 1997) - Direne, A. Intelligent Training Shell for the Operation of Digital Telephony Stations. In: World Conference on Artificial Intelligence in Education - AIED, v. 39, Kobe, Japan, 1997. Proceedings. p. 71-78.

(Félix et al., 1998) - Félix, L.C.M.; Rezende, S.O.; Doi, C.Y.; Romanato, M.J. MLC++ Biblioteca de Aprendizado de Máquina em C++ Versão 1.o. São Carlos/SP, ICMC (Instituto de Ciências Matemáticas e de Computação)-USP (Universidade de São Paulo), 1998. (Relatório Técnico, $\mathrm{n}^{\circ} .72$ ISSN-0103-2569) 
(Garzotto et al., 1993) - Garzotto, F.; Paolini, P.; Schwabe, D. HDM - A Model-Based Approach to Hypertext Application Design. ACM Transactions on Information Systems, v. 11, nº 1, p. 1-26, 1993.

(Goonatilake \& Khebbal, 1995) - Goonatilake, S., Khebbal, S., Intelligent Hybrid Systems: Issues, Classifications and Future Directions (Chapter 1), Intelligent Hybrid Systems, S. Goonatilake and S. Khebbal (eds.), Ed. Jonh Wiley \& Sons Ltd., 1995.

(Hammond, 1989) - Hammond, N. Hypermedia and Learning: Who Guides Whom?. Lecture Notes in Computer Science, G. Goos \& J. Hartmanis (eds.), Computer Assisted Learning, 2nd. International Conference, ICCAL'89, Dallas, Texas, pp. 167-181, 1989.

(Hannafin \& Peck, 1988) - Hannafin, M. J.; Peck, K. L. The Design, Development, and Evaluation of Instructional Software. New York, MacMillan Publishing Company, 1988.

(Jones, 1996a) - Jones, S. R.; Miles, J. C.; Read, M. W. Standardising the Elimination of Unnecessary Data from Interview Transcripts for the Purposes of Knowledge-Based Systems A Case Study. Expert Systems, v. 13, n. 1, 1996, p. 3-14.

(Jones, 1996b) - Jones, S. R.; Miles, J. C.; Read, M. W. A Comparison of Knowledge Elicitation Methods. Expert Systems, v. 13, nº. 4, 1996, p. 277-295.

(Jong, 1991) - Jong, T. Learning and Instruction with Computer Simulations. Education \& Computing, v. 6, p. 217-229, 1991.

(Kass, 1994) - Kass, A. The Casper Project : Integrating Simulation Case Presentation and Socratic Tutoring to Teach Diagnostic Problem-Solving in Complex Domains. The Institute of the Learning Science, Northwestern University, Evanston, Ilinois, 1994. (Relatorio Técnico) (Kolodner, 1992) - Kolodner, J.L. An Introduction to Case-Based Reasoning. Artificial Inteligence Review, $n^{\circ}$. 6, p. 3-34, 1992.

(Kuyper et al., 1993) - Kuyper, M.; Bredeweg, B.; Hoog, R.; Hulst, A. SMISLE (System for Multimedia Integrated Simulation Learning Environments): Authoting Methodology, 1993. (Large, 1996) - Large, A. Hypertext Instructional Programs and Learner Control: A Research Review. Education for Information, v. 14, nº. 2, p. 95-106, 1996.

(McGraw \& Briggs, 1989) - McGraw, K. L.; Briggs, K. H. Knowledge Acquisition: Principles and Guidelines. Ed. Preentice Hall, 1989. 
(Norman \& Draper, 1986) - Norman, D.A.; Draper, S.W. User Centered System Desing. Hilldale, NJ: Lawrence Erlbaun, 1986.

(Nunes \& Fortes, 1997) - Nunes, M. G. V.; Fortes, R. P. Roteiros em Aplicações de Ensino: A Questão do Controle do Leitor. In: III Workshop em Sistemas Multimídia e Hipermidia, São Carlos/SP, 1997. Anais. p. 15-27.

(Nunes et al., 1993) - Nunes, M.G.V.; Turine, M.A.S.; Maltempi, M.V.; Hasegawa, R. Uso de Hipertexto/Hipermídia em Sistemas Tutores Inteligentes. São Carlos/SP, ICMC (Instituto de Ciências Matemáticas e de Computação)-USP (Universidade de São Paulo), 1993. (Notas Didáticas, $n^{\circ}$. 9)

(Nwana, 1990) - Nwana, H.S. Intelligent Tutoring Systems: An Overview. Artificial Intelligence Review, v. 4, p. 251-277, 1990.

(Pansanato, 1998) - Pansanato, L. T. E. Modelagem de Aplicações Hipermidia no Ensino. São Carlos/SP, 1998. Dissertação (Exame de Qualificação), ICMC (Instituto de Ciências Matemáticas e de Computação)-USP (Universidade de São Paulo).

(Preece et al., 1994) - Preece J.; Rogers Y.; Sharp H.; Benyon D. Human-Computer Interaction. Ed. Addison-Wesley, 1994.

(Pugliesi, 1997) - Pugliesi, J. B. Sistema Hibrido Inteligente para Suporte a um Ambiente de Treinamento e Ensino. São Carlos/SP, 1997. Dissertação (Exame de Qualificação, ICMC (Instituto de Ciênicas Matemáticas e de Computaçāo)-USP (Universidade de São Paulo). (Rich \& Knight, 1993) - Rich, E.; Knight, K. Inteligência Artificial. $2^{2}$ ed., Rio de Janeiro/RJ, Ed. Makron Books, 1993.

(Rodrigues \& Monard, 1993) - Rodrigues, S. R.; Monard, M. C. Sistemas Baseados em Conhecimento: Conceitos Fundamentais e Aplicações. In: 1' Jornada USP-SUCESU/SP de Informática e Telecomunicaçð̃es, São Paulo/SP, 1993. Anais. p. 355-364.

(Rodríguez, 1997) - Rodríguez, C. H. WWW: Knowlege Acquisition: Techniques and Barries do Knowledge Acquisition, http://www.osiris.sund.ac.uk/cs0che/chweb/paper2/htm. 1997, 9p.

(Schank, 1990) - Schank, R.C. Case-Based Teaching: Four Experience in Educational Software Design. Interactive Learning Environments, v. 1, Issue (4), 1990, p. 231-253.

(Schank, 1994) - Schank, R.C. Active Learning Through Multimedia. IEEE Multimedia, p. 69-78, 1994. 
(Shute \& Glaser, 1990) - Shute, V.J.; Glaser, R. A Large-Scale Evaluation of an Intelligent Discovery World: Smithtown. Interactive Leaming Environments, v.1, 1990, p. 51-77.

(Tecuci \& Kodratoff, 1995) - Tecuci, G.; Kodratoff, Y. Machine Learning and Knowledge Acquisition: Integrated Approaches. Ed. Academic Press, 1995.

(Towne et al., 1990) - Towne, D.M.; Munro, A.; Pizzini, Q.A.; Surmon, D.S.; Coller, L.D.; Wogulis, J.L. Model-Building Tools for Simulation-Based Training. Interactive Leaming Environments, v. 1, p. 33-50, 1990.

(Valente, 1993) - Valente, J. A. Computadores e Conhecimento: Repensando a Educaçäo. Campinas/SP, Ed. Gráfica Central da UNICAMP, 1993.

(Vassileva, 1990) - Vassileva, J. A Classification and Synthesis of Students Modeling Techniques in Intelligent Computer - Assisted Instruction. Lecture Notes in Computer Science, Computer Assisted Leaming 3rd. International Conference, ICCAL'90, Ed. Springer - Verlag, 1990.

(Venetianer, 1996) - Venetianer, T. HTML: Desmistificando a Linguagem da Internet. São Paulo/SP, Ed. Makron Books, 1996.

(Viccari \& Moussalle, 1990) - Viccari, R.M.; Moussalle, N. Tutores Inteligentes para o Ensino da Linguagem Prolog. In: I Simpósio Brasileiro de Informática na Educação, Rio de Janeiro/RJ, 1990. Anais. p. 203-220.

(White \& Frederiksen, 1990) - White B.Y.; Frederiksen, J.R. Causal Model Progression as a Foundation for Intelligent Learning Environments. Artificial Inteligence, v. 42, 1990 , p.99157.

(Woolf \& McDonald, 1984) - Woolf, B.; McDonald, D.D. Building a Computer Tutor: Desing Issues. IEEE Computer, 1984, p. 61-73. 


\section{Apêndice 1}

\section{Hypertext Design Model (HDM)}

O $\mathrm{HDM}^{6}$ (Hipertext Design Model) (Garzotto et al., 1993), é um modelo para descrever aplicações hipermídia. Uma aplicação (hiperdocumento) no HDM consiste de estruturas de informação chamadas entidades, que denotam um objeto físico ou conceitual do domínio, e são agrupadas em tipos de entidades (entity types). Por exemplo, um "motor elétrico" é uma entidade do tipo "equipamento".

Uma entidade é uma hierarquia de componentes. Os componentes são compostos de unidades, sendo que cada unidade corresponde a um componente associado com uma perspectiva específica, ou seja, uma unidade mostra o conteúdo de um componente sob uma perspectiva. As hierarquias de componentes podem ser deduzidas por vários critérios semânticos, por exemplo, a relação "é-parte-de" é um dos critérios mais usados. No HDM, esse recurso é puramente sintático, servindo apenas para organizar a informação em blocos de construção homogêneos dentro de uma aplicação.

As entidades derivam seu conteúdo a partir de seus componentes que, por sua vez, derivam de suas unidades. As unidades são os menores conjuntos de informação que podem ser visualizados, e são semelhantes à noção de nós em hipertexto. A perspectiva é um recurso sintático para organizar as informações que devem ser apresentadas de formas alternativas, por exemplo, uma mesma informação pode ser visualizada em português e inglês, ou usando mídias diferentes, como texto, gráfico, imagem, vídeo, áudio, etc.

As estruturas de informação (entidades, componentes e unidades) podem ser conectadas por três categorias de elos (links): Elos Estruturais - conectam os componentes de uma mesma entidade; Elos de Perspectivas - conectam as unidades de um mesmo componente; e Elos de Aplicação -

\footnotetext{
${ }^{6}$ Este resumo sobre HDM foi extrafdo de (Pansanato, 1998).
} 
indicam os relacionamentos dependentes do domínio, e conectam componentes e entidades de maneira arbitrária e definida pelo autor. Os elos de aplicação são organizados em tipos, que são especificados através de um nome, do tipo das entidades origem e destino, e de um atributo (simétrico ou assimétrico) indicando se o tipo possui um elo inverso.

A Figura 1 mostra um exemplo das estruturas de informação e dos elos do HDM. Esse exemplo possui duas entidades, $A$ e $B$, com um elo de aplicação indicando um relacionamento entre . essas entidades. A entidade $A$ possui os componentes $A 1$ e $A 2$, conectados à entidade através de elos estruturais; o mesmo para a entidade $B$ que possui os componentes $B 1, B 2$ e $B 3$ conectados a ela através dos elos estruturais. O componente $B 3$ possui três unidades conectadas através de elos de perspectivas, que correspondem à possibilidade de apresentar informação sobre o componente na forma de foto, texto e mapa.

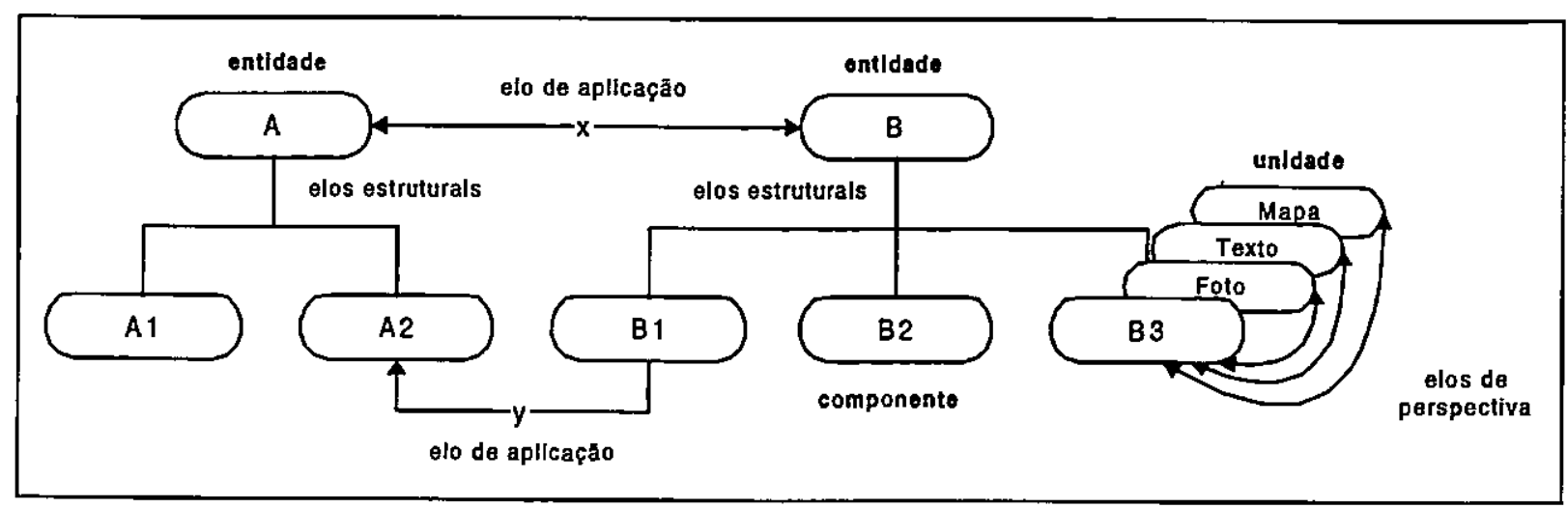

Figura 1- Exemplo das estruturas de informaçäo e elos do HDM.

As categorias de elos e os tipos de elos de aplicação são utilizados com o objetivo de simplificar o trabalho do projeto, induzir o uso consistente de elos, criar padrões de navegação e possibilitar a derivação automática de um número significativo de elos a partir da especificação.

O HDM faz uma distinção entre as noções de esquema (schema) e instância de esquema. Um esquema é uma coleção de definições de tipos (entidades e elos de aplicação) que descrevem uma aplicação em nível global; uma instância de um esquema é uma coleção de entidades, componentes, unidades e elos que satisfazem as definições do esquema. Essa característica pode permitir a reutilização do mesmo esquema para diferentes aplicações do mesmo domínio.

A Figura 2 mostra um exemplo de esquema que procura descrever a informação manipulada em uma organização de créditos, na qual os documentos são manipulados conforme procedimentos. 
Os documentos e procedimentos são definidos de acordo com leis, regulamentos e normas informais.

Apesar do HDM ser principalmente utilizado para a modelagem de aplicações, ele fornece uma semântica de navegação padrão (default browsing semantics), derivada diretamente da especificação e compatível com a navegação comum de nós e elos encontrada em muitos sistemas. Entretanto, é possível definir semânticas de navegação específicas para um determinado sistema alvo da aplicação.

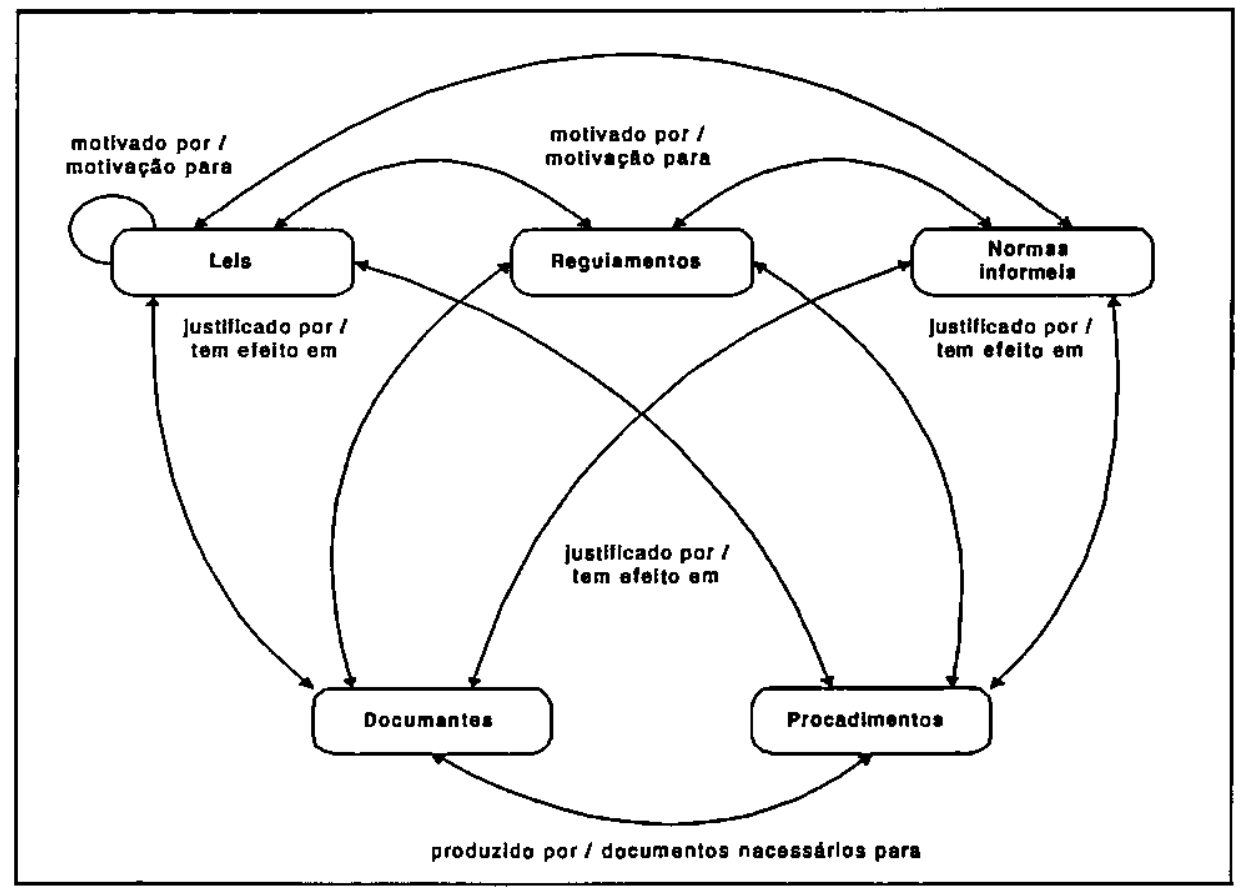

Figura 2 - Exemplo das estruturas de informação e elos da HDM.

A navegação pode ser realizada percorrendo os elos definidos em uma instância de esquema. Entretanto, para acessar diretamente as estruturas de informação, são utilizadas as estruturas de acesso (outlines), que fornecem pontos de entrada apropriados (como um índice, por exemplo) e não são especificadas no esquema, sendo livremente adicionadas ou modificadas em uma aplicação.

O modelo HDM pode ser usado como uma máquina de modelagem ou como uma máquina de implementação. Como uma máquina de modelagem, ele suporta a produção de especificações de alto nível de aplicaçōes na maior parte dos domínios; como máquina de implementação, ele é a base para ferramentas de projeto que suportam diretamente o desenvolvimento de aplicaçōes. 


\section{Apêndice 2}

\section{Aquisição de Conhecimento}

A Aquisição de Conhecimento (AC) ${ }^{7}$ é um estágio crucial no desenvolvimento de sistemas inteligentes. Como um processo, a AC envolve a extração, interpretação e representação do conhecimento de um dado domínio e é considerada como sendo o estágio mais difícil e precário na construção de sistemas inteligentes. Além disso, a AC não utiliza apenas uma disciplina, é uma área que inclui principalmente psicologia cognitiva e Inteligência Artificial (Goonatilake \& Khebbal, 1995). Capturar conhecimento de um especialista do domínio é um dos vários componentes no processo de construção de um Sistema Inteligente (Rodríguez, 1997).

Engenharia do Conhecimento é o processo que estuda a transferência de conhecimento do Especialista para o Computador. Esse processo é efetuado por profissionais conhecidos como Engenheiros de Conhecimento cuja função específica é extrair o conhecimento do(s) especialista(s) (ou de outra fonte) interpretá-lo e representá-lo em tipos e estruturas de conhecimento na Base de Conhecimento.

Alguns pontos devem ser levados em consideração na escolha da equipe de engenheiros de conhecimento, como: habilidade para aprendizado, comunicação, organização, conceitualização, diplomacia, documentação e conhecimento de técnicas de desenvolvimento de Sistemas Inteligentes.

Adquirir conhecimento especialista envolve: obtenção de informação dos especialistas e/ou de fontes documentadas, classificação dessa informação de forma declarativa (factual) ou procedural, codificação dessa informação em um formato utilizado pelo sistema, e checagem de consistência do conhecimento codificado com o conhecimento existente no sistema. A AC pode ocorrer de duas formas Aquisição de Conhecimento Explícito e Aquisição de Conhecimento Implícito. Dentre as várias fontes de conhecimento destacam-se os especialistas, que são pessoas . com alto grau de conhecimento e experiência no domínio.

\footnotetext{
${ }^{7}$ Este resumo sobre Aquisição de Conhecimento foi extraído de (Pugliesi, 1997).
} 
Conhecimento é a chave para Sistemas Inteligentes. Na maioria dos casos a origem para esse conhecimento é o especialista do domínio. O especialista do domínio é um indivíduo selecionado por seu alto grau de conhecimento em um dado campo e pela sua habilidade para comunicar conhecimento. Muitas variáveis determinam as qualificações do especialista do domínio, incluindo se ele é "prático" (comumente ativo no domínio) ou "experiente" (não comumente ativo no domínio). Especialistas do domínio são, muitas vezes, únicas fontes de informação os quais as companhias especializadas desejam preservar. Em outros casos, vários especialistas do domínio podem ser visitados para oferecer especialidade, que podem ser combinadas e compartilhadas entre os trabalhadores menos especializados (McGraw \& Briggs, 1989).

Para selecionar especialistas apropriados, engenheiros de conhecimento devem identificar experiências, características e atributos que os permitirão alcançar os objetivos de desenvolvimento da base de conhecimento. A identificação dos requisitos dos especialistas do domínio é apenas o primeiro passo. Esses especialistas devem ter experiência no domínio. Pode acontecer que os especialistas disponíveis não possuam conhecimento atualizado, embora tenham vasta experiência sobre como exercitar habilidades cognitivas profundas dentro do domínio. Especialistas que tiveram que treinar outros no domínio podem saber expressar melhor seus conhecimentos.

Dentre as características pessoais dos especialistas que participarão da equipe de Engenharia de Conhecimento, deve haver: habilidade de comunicação, paciência, dedicação ao trabalho, honestidade, organização e disponibilidade.

\section{$>$ Aquisição de Conhecimento Explícito ou Manual}

Nesse tipo de AC é necessária a presença de um ou mais Especialistas do Domínio, a partir dos quais, Engenheiros de Conhecimento farão toda a extração do conhecimento necessário para o desenvolvimento do sistema, armazenando em um Base de Conhecimento (Figura 1) (Jones, 1996a; Jones, 1996b). 


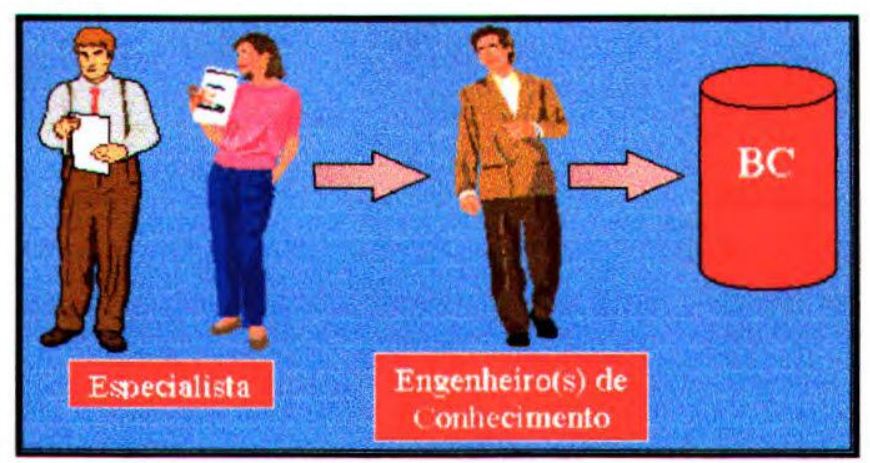

Figura 1 -Aquisição de Conhecimento Explicito ou Manual.

Existem vários tipos de $\mathrm{AC}$ Explícito que veremos uma rápida descrição na Tabela 1 a seguir:

Tabela 1 - Tipos de Aquisição de Conhecimento Explícito

\begin{tabular}{|c|l|}
\hline Tipo & \multicolumn{1}{|c|}{ Descrição } \\
\hline Entrevista & $\begin{array}{l}\text { É a técnica mais utilizada por Engenheiros de Conhecimento para a elicitação de } \\
\text { conhecimento a partir de um especialista (McGraw \& Briggs, 1989). }\end{array}$ \\
\hline Brainstorming & $\begin{array}{l}\text { Originou-se da preocupação dos altos executivos de negócios para com os gerentes que eles } \\
\text { supervisionavam. Estes sempre repetiam e imitavam a sabedoria de seus superiores. Embora } \\
\text { isso fosse uma maneira politicamente segura de agir, acabava por excluir as idéias deles que } \\
\text { pudessem ser úteis. Assim, criou-se essa técnica para encorajar a criatividade em grupo } \\
\text { (McGraw \& Briggs, 1989). }\end{array}$ \\
\hline $\begin{array}{c}\text { Análise de } \\
\text { Protocolos }\end{array}$ & $\begin{array}{l}\text { É um método usado para entender a maneira como uma pessoa resolve um problema e as } \\
\text { operações especificas utilizadas para mover-se de um estado de conhecimento para outro } \\
\text { (McGraw \& Briggs, 1989). }\end{array}$ \\
\hline $\begin{array}{c}\text { Rastreamento de } \\
\text { Processo }\end{array}$ & $\begin{array}{l}\text { Uma série de técnicas que permitem a determinação do processo (modo) de pensar de um } \\
\text { indivíduo enquanto ele realiza a tarefa ou chega a uma conclusão (McGraw \& Briggs, 1989). }\end{array}$ \\
\hline Estudo de Casos & $\begin{array}{l}\text { Através de casos já documentados, elicita-se o conhecimento do especialista. Os casos devem } \\
\text { cobrir várias possibilidades dentro do domínio, para elicitar conhecimentos específicos. O } \\
\text { estudo de casos é útil para identificar sutilezas do especialista na tomada de decisões. }\end{array}$ \\
\hline Introspeção & $\begin{array}{l}\text { O especialista verbaliza sensações, memórias, sentimentos e imagens que percebe enquanto } \\
\text { resolve um problema. Essa técnica é útil para obter uma estratégia global da forma de } \\
\text { resolução do problema. As formas mais comuns de introspecção são: descrição retrospectiva } \\
\text { (casos passados), simulação de um cenário (casos hipotéticos) e episódio crítico (casos } \\
\text { dificeis). }\end{array}$ \\
\hline Repertório Grid & $\begin{array}{l}\text { É uma técnica para elicitação e análise de um modelo do domínio do especialista. A teoria } \\
\text { estabelece que cada pessoa age como um "cientista" que classifica e organiza o seu mundo. } \\
\text { Baseado nessas classificações, o indivíduo está apto a construir teorias de como um Domínio } \\
\text { particular funciona, e agir no Domínio baseado em suas teorias pessoais. }\end{array}$ \\
\hline
\end{tabular}




\section{Aquisição de Conhecimento Implícito ou Automático}

Esse tipo de Aquisição de Conhecimento tem como objetivo extrair conhecimento de dados e/ou informações referentes ao domínio, sem a necessidade de grande envolvimento de especialistas humanos.

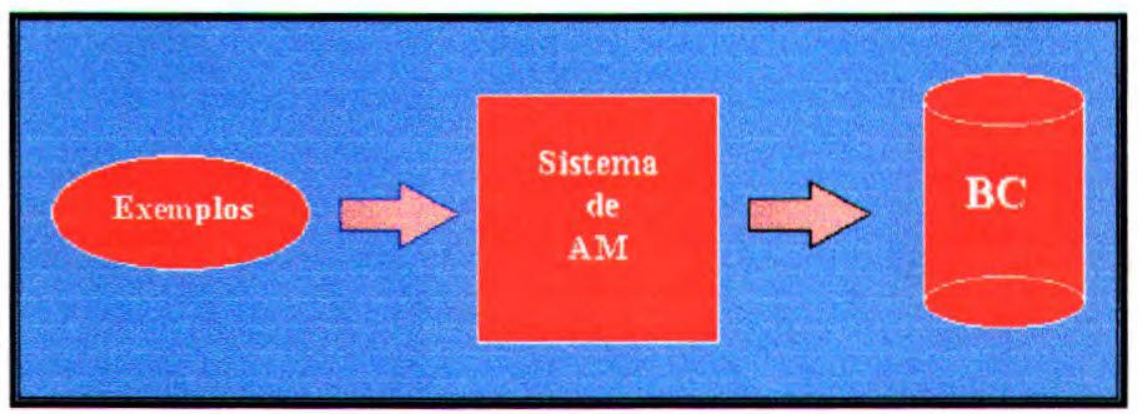

Figura 2 - Aquisição de Conhecimento Implicito ou Automática

Podemos citar como um exemplo desse tipo de AC, o Aprendizado de Máquina (AM), subárea de Inteligência Artificial que pesquisa métodos computacionais relacionados à aquisição de conhecimentos, novas habilidades e novas formas de organizar o conhecimento já existente, tendo por objetivo um melhor entendimento dos mecanismos de aprendizado dos seres humanos e a automação da AC. Pesquisas em AM concentram-se no desenvolvimento de algoritmos autônomos para adquirir conhecimento a partir de dados e na compilação e organização desse conhecimento. Entretanto, devido à complexidade desse problema, a aplicação de AM tende a ser limitada a domínios simples. Deve-se, também, em AM, testar experimentalmente o conhecimento aprendido em conjuntos independentes de dados (Tecuci \& Kodratoff, 1995).

Sistema de Aprendizado é um programa de computador que toma decisões baseado em experiências acumuladas contidas em casos resolvidos com sucesso (Batista, 1997). Mais especificamente, ele se concentra em uma das tarefas de aprendizado mais básicas proeminente: a classificação ou predição. O objetivo fundamental de um sistema de aprendizado está em extrair conhecimento, por exemplo, na forma de regras de decisão, de um conjunto de dados tal que essas 
regras possam ser aplicadas a novos dados. "Aprender" consiste em escolher ou adaptar parâmetros da representação do modelo, no paradigma escolhido, de forma que o modelo classifique corretamente os exemplos conhecidos bem como novos exemplos.

\section{$>$ Problemas que ocorrem durante a Aquisição de Conhecimento}

Independentemente das habilidades do Engenheiro de Conhecimento, a natureza interpessoal da sessão de AC, juntamente com a dificuldade da tarefa, assegura que problemas devam surgir (McGraw \& Briggs, 1989). As seguintes dificuldades serão, muito provavelmente, evidentes por elas mesmas:

- negativismo e apatia;

- falta de compromisso;

- blocos de comunicações verbais e não verbais;

- hostilidade e reações defensivas;

- conflitos entre expectativas e realidades;

- conhecimento irrelevante, incorreto, incompleto ou inconsistente;

- incapacidade do especialista de verbalizar o seu conhecimento e/ou raciocínio;

- discordância entre múltiplos especialistas. 